\title{
FLOODS OF OCTOBER 1954 \\ IN THE CHICAGO AREA \\ ILLINOIS AND INDIANA
}

\author{
By \\ Warren S. Daniels \\ and \\ Malcolm D. Hale \\ Prepared in cooperation with the \\ STATES OF ILLINOIS AND INDIANA
}

Open-file report

Washington, D. C., 1955 


\title{
FLOODS OF OCTOBER 1954 \\ IN THE CHICAGO AREA \\ ILLINOIS AND INDIANA
}

\author{
By \\ Warren S. Daniels \\ and \\ Malcolm D. Hale
}

Prepared in cooperation with the

STATES OF ILLINOIS AND INDIANA

Open-file report

Washington, D. C., 1955 


\section{PREFACE}

This preliminary report on the floods of October 1954 in the Chicago area of Illinols and Indiana was prepared by the Water Resources Division, C. G. Paulsen, chief, under the general direction of J. V. B. Wells, chief, Surface Water Branch.

Basic records of discharge in the area covered by this report were collected in cooperation with the Illinols Department of Public Works and Bulldings, Division of Waterways; the Indiana Flood Control and Water Resources Commission; and the Indiana Department of Conservation, Division of Water Resources.

The records of discharge were collected and computed under the direction of J. H. Morgan, district engineer, Champaign, IIl.; and D. M. Corbett, district engineer, Indianapolis, Ind. The data were computed and text prepared by the authors in the district offices in Illinols and Indiana. The report was assembled by the staff of the Technical Standards Section in Washington, D. C., Tate Dalrymple, chief. 


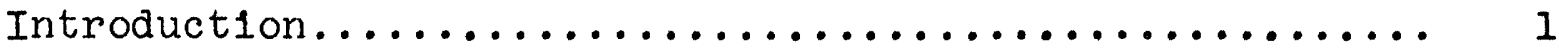

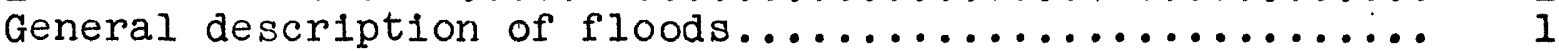

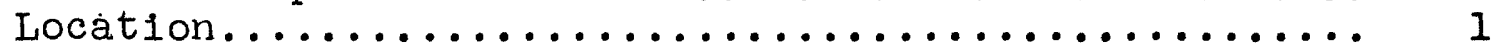

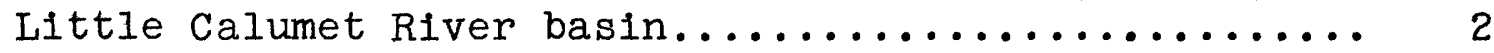

Kankakee River basin......................... 5

Des Pla1nes River basin....................... 5

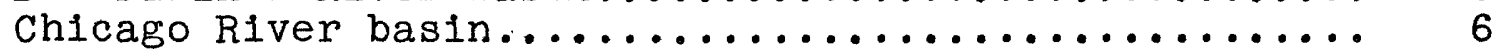

Du Page and Fox River basins.................. 8

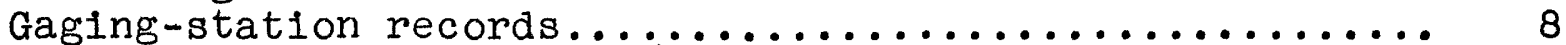

Explanation of data......................... 8

Hart ditch at Munster, Ind.................... 10

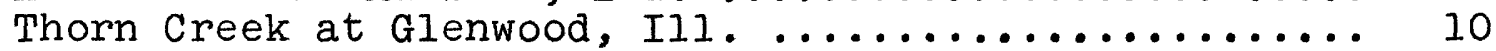

Deer Creek near Chicago Heights, Ill. ............ 11

Butterfleld Creek at Flossmoor, Ill. .............. 11

Lansing ditch near Lansing, Ili. ............... 11

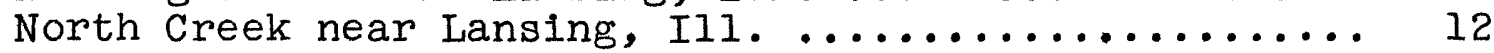

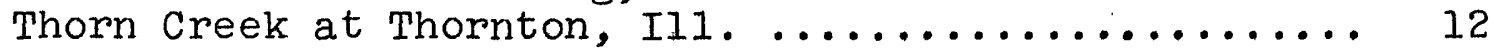

Little Calumet River at South Holland, Ill. ........ 13

Midlothlan Creek at oak Forest, Ill............. 13

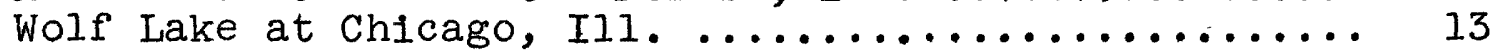

Deep River at Lake George Outlet at Hobart, Ind. .... 14

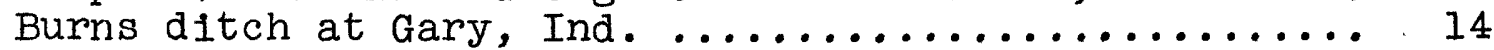

Little Calumet River at Porter, Ind.............. 14

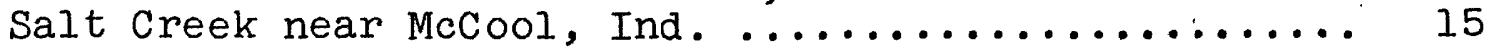

Kankakee River near North Liberty, Ind. .......... 15

Kankakee River at Davis, Ind. ................... 16

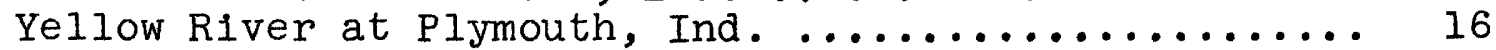

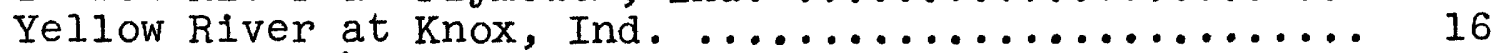

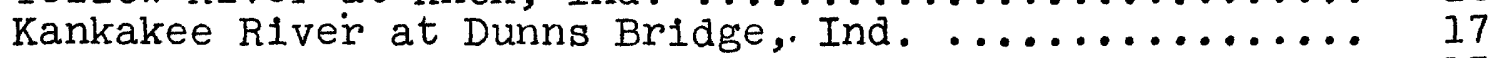

Kankakee River at Shelby, Ind. .................. 17

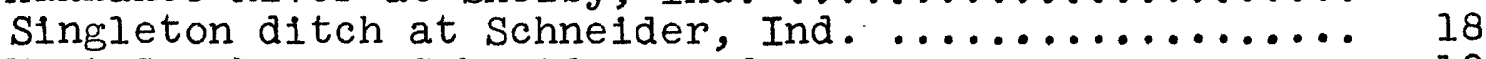

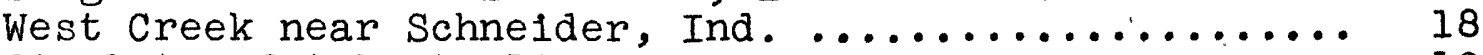

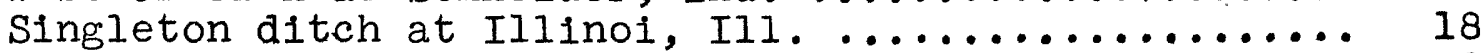

Kankakee River at Momence, IIl. ................ 19

Kankakee River near Wilmington, Ili. ............. 19

Des Plaines River near Gurnee, Ill. .............. 19

Buffalo Creek near wheeling, Ill............... 20

Des Plaines River near Des Plaines, Ill. ........... 20

McDonald Creek near Mt. Prospect, Ill. ........... 21

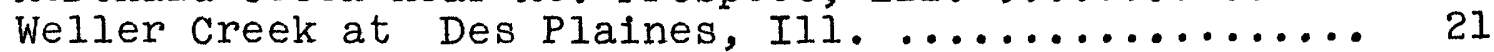

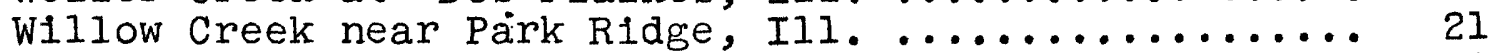

Salt Creek near Arlington Heights, iil. ............ 22

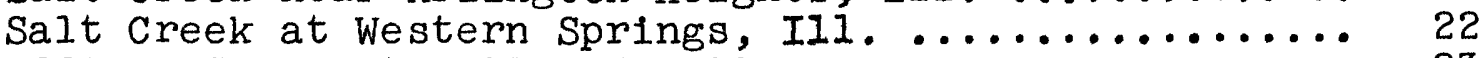

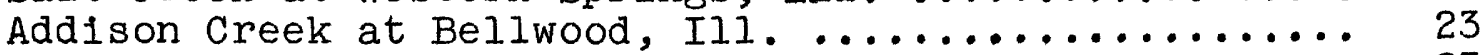

Des Plaines River at Riverside, Iil. .............. 23

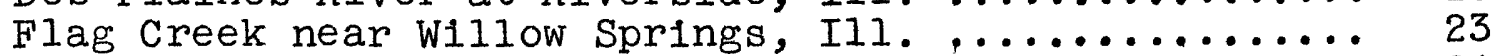

North Branch Chicago River at Deerfield, III. ...... 24

Skokie River at Lake Forest, Ill. ............. 24 
Gaging-station records--Continued

West Fork of North Branch Chicago River at

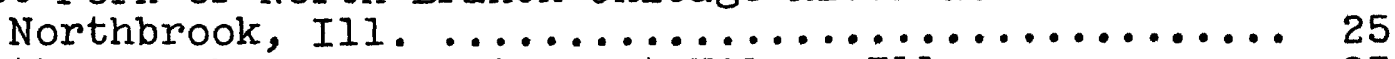

North Branch Chicago River at Niles, Ill......... 25

Tiniley Creek near Palos Park, Ill.............. 25

Chicago Sanitary and Ship Canal at Lockport, Ill. .... 26

Long Run near Lemont, Ill. ................. 26

Hickory Creek at Jollet, III. ............... 27

Du Page River at Troy, Ill. ................ 27

Mazon River near Coal City, Ill. .............. 27

Illinols River at Marseliles, Ill. ........... 28

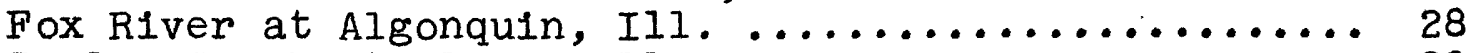

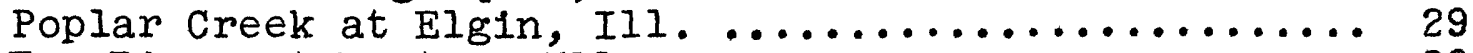

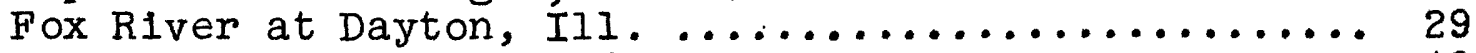

Summary of flood stages and discharges.............. 49

Flood frequency........................... 57

\section{ILLUSTRATIONS}

Figure 1. Map of flood area showing location of

Page

flood-determination points............. 3

2. Map of Chicago area, Cook County, showing

location of flood-determination points......

3. Hydrographs for stations $2-5 \ldots \ldots \ldots \ldots \ldots \ldots$.

4. Hydrographs for stations $6-8,10 \ldots \ldots \ldots \ldots \ldots$

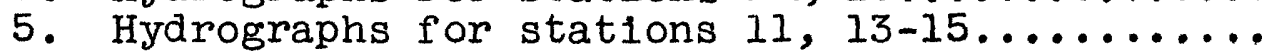

6. Hydrographs for stations $16-19 \ldots \ldots \ldots \ldots \ldots \ldots$

7. Hydrographs for stations $20,21 \ldots \ldots \ldots \ldots \ldots$.

8. Hydrographs for stations $22-24 \ldots \ldots \ldots \ldots \ldots \ldots$

9. Hydrographs for stations $25,29-31 . \ldots \ldots \ldots \ldots$

10. Hydrographs for stations $32-34 \ldots \ldots \ldots \ldots \ldots \ldots$

11. Hydrographs for stations $35-37 \ldots \ldots \ldots \ldots \ldots \ldots$

12. Hydrographs for stations $38-41 \ldots \ldots \ldots \ldots \ldots \ldots$

13. Hydrographs for stations $42,44,45 \ldots \ldots \ldots \ldots$

14. Hydrographs for station $46,48,49 \ldots \ldots \ldots \ldots$.

15. Hydrographs for stations $51,53,54 \ldots \ldots \ldots \ldots$

16. Variation of unit discharge with drainage area

\section{TABLES}

Table 1. Dally and monthly discharge, in cublc feet per second, and runoff, in inches, at gaging stations.......................... 30 2. Summary of fiood stages and discharges........ 50 
FLOODS OF OCTOBER 1954

IN THE CHICAGO AREA

ILLINOIS AND INDIANA

\section{INTRODUCTION}

The greatest flood in the history of Chicago resulted from heavy showers and thunderstorms during the period october 9-11, 1954. The 24-hour rainfall on october 9 and 10 was the greatest in 69 years, and the 48-hour total was the greatest in the 84-year record of the Chicago station. The storms and floods extended into Indiana where previous records were broken. At 24 gaging stations in the area peak discharges exceeded previously recorded maxima.

Occurring in a region that is densely populated and highly industrialized, the floods caused unprecedented damage. Fortunately casualties were few. No lives were lost through causes directly attributable to the floods, although a dozen or more persons were killed in accidents indirectly associated with the storms and floods.

Data presented in this preliminary report include records of streamflow at 50 gaging stations and miscellaneous sites in Illinois and Indiana. A comprehensive flood report, one of a series of water supply papers dealing with the floods of 1954, will be published at a later date.

\section{GENERAL DESCRIPTION OF FLOODS}

\section{Location}

The area associated with floods discussed in this report is centered about Chicago, the Nation's second largest city, and the southern tip of Lake Michigan, including parts of northwestern Indiana and northeastern Illinois. It extends roughly 140 miles east and west, from South Bend and Plymouth, Ind., to Ottawa, III., and about 90 miles north and south from the northern edge of cook County (Chicago metropolitan area) to Kankakee, I11. Much of the region in each state is densely populated and highly industrialized. The map of figure 1 covers the general area of flooding.

There was a narrow belt of heavy rainfall and high runoff in Illinois which extended from Chicago to the Mississippl River in the vicinity of Rock Island, III., and Muscatine, Iowa. West of the Fox River basin the floods were not severe and damage was comparatively small. This farther western area has, therefore, been considered outside the scope of this report. 
The streams affected by the storm and flood include all those tributary to Lake Michigan in Illinois and Indiana, lying in a relatively narrow area along the lake shore, the headwaters of the Kankakee River in Indiana, the entire Des Plaines River basin, and the Du Page and Fox River basins, which are tributary to the Illinois River on the north side of the river.

Figure 1 is a map of northeastern Illinois and northwestern Indiana showing flood-determination points. As there are 26. gaging stations operated in Cook County, figure 2 has been drawn to show that area in greater detail.

\section{Little Calumet River Basin}

The Iittle Calumet River basin is very flat and storm drainage has long been recognized as a problem. Not only did the Little Calumet River go over its banks to flood extensive. areas, but inundation was severe along all the tributary streams in southern Cook County, Illinois. It was reported that every house in the village of Midlothian was surrounded with water, temporar11y marooning 4,400 families. The industrial city of Harvey, 22 miles south of Chicago, was almost completely inundated south of the Grand Trunk railway embankment, including the main business district. Steel plants and oil refineries in Blue Island were damaged. Other towns hard hit were Palos Park, Worth, Oak Iawn, Als1p, Crestwood, Robbins, Posen, Markham, Hazel Crest, Garden Homes, and Homewood.

The experience of Geological Survey engineers in attempting to reach gaging stations in this area was described best as "frustrating", because of the many flooded and impassable highways. An ordinary fifteen-minute drive became a two-hour process of doubling around the maze of highways hunting an open road. The great concentration of railways about chicago has resulted in construction of hundreds of underpasses to avoid grade crossings. Many of these underpasses filled with water and were closed for days after the streams had receded. No complete count is available, but at least 57 underpasses were closed in cook county. A summary of road conditions on October 11 by the cook County Highway Department listed 67 points as being under water and blocked to traffic.

Dredging has greatiy modified the basin characteristics of the Iittle Calumet River. During low flow that portion of the drainage area west of a divide near Georgia street at Gary., Ind., contributes flow which runs west to Iake Michigan or into the Calumet Sag Channel depending on the operation of locks into the Calumet Sag Channel; that portion east of Georgia Street contributes flow which runs east through Burns ditch to Lake Michigan. All of the flow of Deep River, Salt Creek, and that portion of Little Calumet River east of the mouth of Deep River flows into Lake Michigan through Burns ditch. 


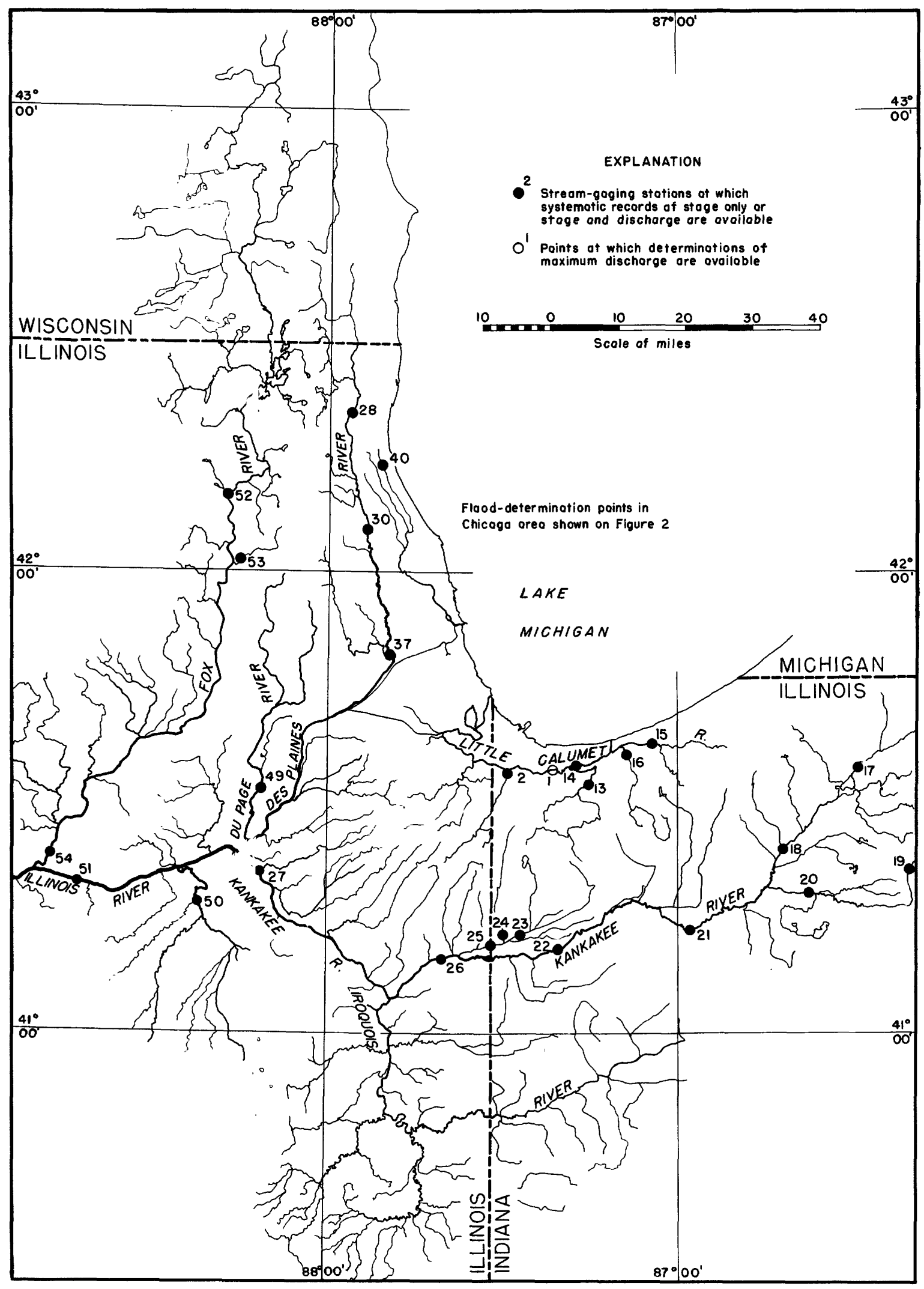

Figure 1.--Map of flood area showing location of flood-determination points 


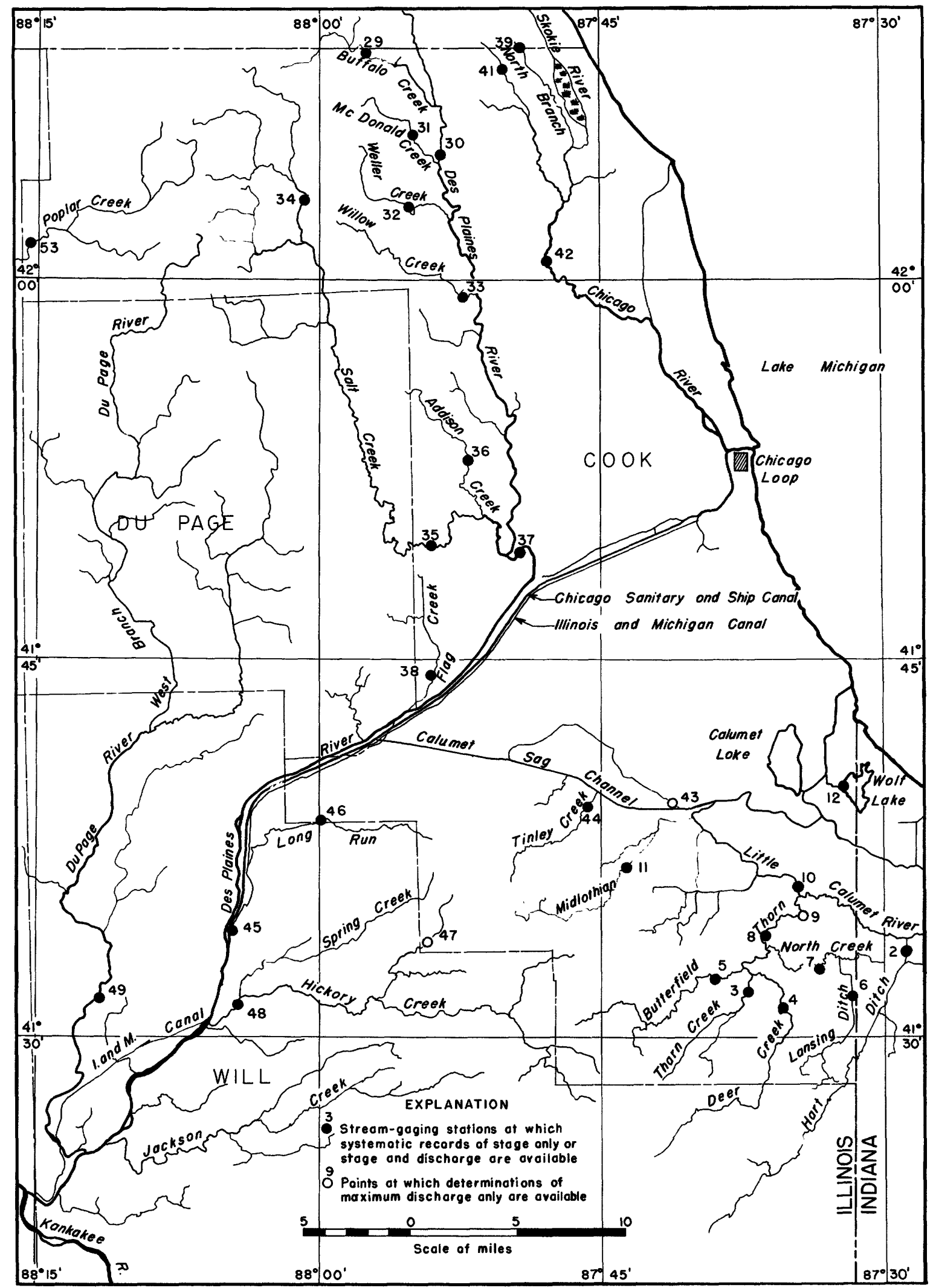

Figure 2.--Map of Chicago area, Cook County, showing location of flood-determination points 
On the rising stage of this flood the flow at the mouth of Hart ditch ran both east and west in the Little Calumet River channel. Most of the flow to the east went into storage inundatIng the large area between Broadway, Gary, Ind., and Hawthorne Drive, Hammond, Ind. A small portion of the flow ran east through Burns ditch to Lake Michigan.

At the time of the peak stage at Grant street, Gary, Ind., the discharge through a culvert was 244 cubic feet per second flowing east. Flood elevations show the dividing point for the flow at peak stage to be near Calumet Avenue, Hammond, Ind., west of the mouth of Hart ditch.

As the stage fell the direction of flow near Hart ditch reversed, water came out of storage, and flowed west. Prolonged inundation occurred over a large area in the basin.

\section{Kankakee River Basin}

Extreme flooding occurred in the upper portion of the Kankakee River basin. The Yellow River at Knox, Ind., had a peak discharge 80 percent greater than the previous maximum in 12 years of record. Because of the flat terrain large areas were flooded when the streams went out of their banks, resulting in some intermingling of flood waters across normal drainage divides. Wide-spread flooding of the flat terrain resulted in a large volume of storage and a very slow-moving flood crest along the main stem of the Kankakee River. At Shelby, Ind. the crest occurred on October 27,17 days after the rain.

The lower Kankakee River (in Illinols) suffered only moderate flooding, but the peaks occurred earlier. The station at Momence, close to the Indiana line crested october 15. Nearer the mouth, at Wilmington station, the peak was recorded october 12 . This progressively earlier cresting is attributed to heavier flood runoff from the tributary area on the right bank between the river and southern Cook County.

\section{Des Plaines River Basin}

Northwest and west of Chicago proper the Des Plaines River and tributaries caused considerable damage, although less than the Little Calumet River basin streams caused elsewhere.

Salt Creek and Addison Creek flood stages were higher than previously recorded although the discharge at Salt Creek at Western Spring, Ill., was less than for the March 1948 flood. Newspapers reported 5,000 basements flooded in La Grange and 600 in Western Springs. Thousands of calls for assistance in pumping 
out cellars were received by fire departments throughout the Chicago area. Because of the potential hazard in having telephone service tied up, it was necessary to broadcast radio appeals to the public not to call fire departments except for fire emergencies. Higgins Road, the Northwest Highway, and North Road--all major highways--were flooded and temporarlly closed.

Along the Des Plaines River to the southwest the tributaries were extremely high and local damage and blocking of roads resulted. The gently rolling and hilly topography differs from that of the flat lowland along the lake shore. Flag Creek and Long Run had the highest unit peak runoff determined in the flood area, 80.2 and 152 cubic feet per second per square mile, respectively, at the gaging station on each creek. Hickory Creek at Joliet, Ill., did not equal the April 1947 flood peak and damage was correspondingly less. However, hundreds of basements were flooded and the American steel and Wire Plant was shut down for two days.

\section{Chicago River Basin}

The Chicago River is formed by the confluence of the North and South Branches, and reaches Lake Michigan just north of the Chicago Loop, heart of the great city. The North Branch Chicago River has its headwaters close to Lake Michigan, well north of the Cook County IIne, and outside the heavier storm area. Flood damage was chiefly in the flat areas of the Skokie lagoons in Skokie and Evanston. The Edens Expressway and the Skokie H1ghway, major routes to the north, were blocked during the flood.

The South Branch Chicago River is short and has been developed as a navigation channel, forming part of the Chicago Sanitary and Ship Canal, which diverts water from Lake Michigan to the Des Plaines River at Lockport and thence into the I11ino1s and Mississippi Rivers. Since 1900, when a lock was completed at the mouth of the Chicago River, flow has been away from the lake into the Des Plaines River, with the Chicago River level being held usually about 3 feet lower than lake level. During this flood the river rose to the highest stage on record, 5.4 feet above Chicago City Datum or 585.3 feet above mean sea level, datum of 1929, at the mouth. Th1s was about 3.4 feet higher than lake level at the time.

To relieve the flood, which was causing unprecedented damage and threatening an even greater disaster, the Sanitary District of Chicago ordered the lock gates at the mouth of the river to be opened, allowing the river to discharge into Lake Michigan for the first time in 54 years. The lock gates were operated as follows: 


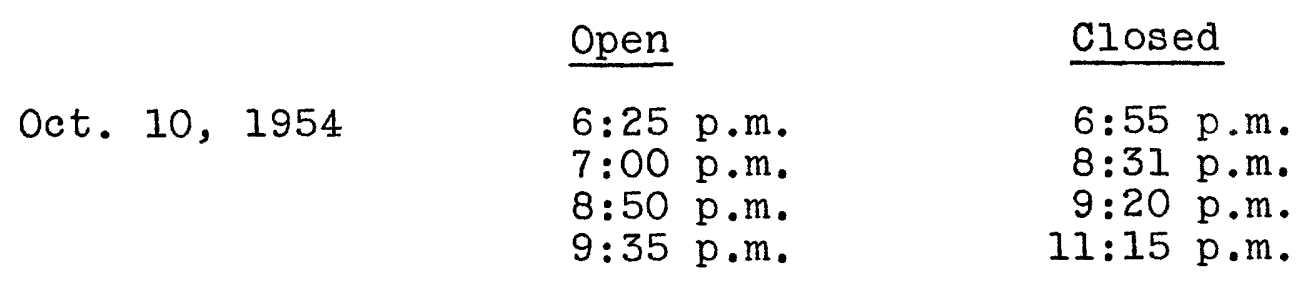

The three short periods of closure were for lockage of boats. The Sanitary District of Chicago has estimated the total discharge at this point into Lake Michigan to be approximately 129,600,000 cubic feet. During about the same period gates were opened to permit discharge into the lake from the North Shore Channel at Wilmette. The discharge here has been estimated at approximately $172,800,000$ cubic feet by the Sanitary District of Chicago. Normaliy lake water is pumped into the North Shore Channel at Wilmette to flush storm and sanitary sewage from the northern district down into the North Branch Chicago River and the Chicago Sanitary and Ship Canal.

As the Chicago water supply is taken from Lake Michigan, possible contamination from the polluted river discharge was a grave threat. Emergency precautions were taken, including hourly sampling of lake water and increased chlorination at pumping stations. The city supply was pronounced safe, but residents in 17 southern and western suburbs depending on well-water supplies were cautioned to boil their drinking water.

Before the peak was reached the Chicago River had burst over its walled banks to fluod rallroad yards and the basements of many bulldings. All 29 tracks of the Union Station were covered and water was 10 feet deep in the baggage room. Passengers on trains of the Burlington Railroad, Milwaukee Railroad, and Pennsylvania Railroad, detrained in yards or at outlying points and continued their way by street car or whatever means could be improvised. About 40,000 west-suburban commuters were delayed and through travelers were advised to make telephone inquiry on how and where to make railroad connections. The post office basement was flooded damaging more than 3,000 pleces of parcelpost mail. The Chicago Daily News had 42 feet of water in its basement and subbasement, forcing it to use the facilities of other newspapers for publication on October 11.

Flood waters from the South Branch Chicago River and the Chicago Sanitary and Ship Canal put out of operation the two largest electric generating plants of the Commonwealth Edison Co., Crawford Station on South Pulaski Road and Fish Station on Cermak Road. Loss of the 350,000 kilowatt output of these plants forced shutdown of manufacturing establishments and a 50 percent cut in consumption of power over a widespread area including The Loop. As an emergency measure the Illinois Bell Telephone Co. cut down its power demands by ordering diesel generators into operation at 
exchange buildings. The power company was able to furnish adequate power to the Chicago Transit Authority so that street-car operation was not curtailed.

\section{Du Page and Fox River Basins}

The Du Page River at Troy, III., reached a new maximum for the 15-year period of record, exceeding the March 1948 flood. State Highways 53, 55, and 59 were blocked by high water near Lisle, Warrenville, and Plainfield, Ill., respectively, each town suffering extensively from the flood.

The Fox River, which has its headwaters in Wisconsin and flows through the Fox chain of lakes near the northern edge of Illinois, had only a small rise at Algonquin, downstream from the lakes. From Aurora south on the main stream and on the tributarles to the west, the storm caused record-breaking floods. The peak discharge at the gaging station at Dayton, with a drainage area not quite double that at Algonquin, was 60 percent greater than the previous maximum (March 1948) and the highest in 29 years of record. The National Guard was alerted and put on guard duty because of fear of failure of the powerplant dam at Dayton, which would have caused disaster at ottawa, only a few miles downstream. It was necessary to sandbag the head race to the plant, but fortunately the flood was passed without damage to the dam.

Low-lying areas at ottawa at the mouth of Fox River were flooded, both by the Fox River and by the crest which came down the Illinois River at about the same time. Residents were evacuated from the affected area, and an appeal was made for National Guard troops to prevent looting in waterfront areas.

\section{GAGING-STATION RECORDS \\ Explanation of Data}

This section of the report contains, in condensed form the streamflow information collected during the flood by the Geological Survey at the established gaging stations. Data for the 50 stations are presented in three parts: first, the station descriptions; second, a table of daily discharges (table 1); and third, discharge hydrographs at most of the gaging stations during the immediate period encompassing the peaks (figures 3-15). 
At stream-gaging stations records of stage are obtained either from the continuous trace of a water-stage recorder or by periodic direct readings on a nonrecording gage. Discharge measurements are generally obtained by current meter and occasionally by indirect methods. A stage-discharge relation curve is developed on basis of the discharge measurements and the corresponding stages, and from this curve discharges for indicated stages are obtained.

The description for each gaging station gives information concerning the location and datum of gage, size of drainage area above the gage, nature of gage-helght record obtained during the flood period, definition of the stage-discharge relation, maximum stage and discharge during the present flood, previous maximum of record, and other pertinent information.

Daily mean discharges for gaging stations are tabulated in table 1, which follows the group of station descriptions. Daily figures, in cubic feet per second, and the monthly mean discharge, in cubic feet per second, and runoff, in inches, are shown for the month of october. For the station, (12) Wolf Iake at Chicago, Ill., daily mean gage heights, in feet, are shown, discharge not being determined at this station.

Discharge hydrographs for most of the stations are presented for the period of flooding in figures 3-15. Because flooding was not extreme or because daily changes were not excessive, detalled hydrographs for the following stations were not included: (12) Wolf Lake at Chicago, Ill., (26) Kankakee River at Momence, IIl., (27) Kankakee River near Wilmington, III., and (28) Des Plaines River near Gurnee, IIl.

All gaging stations are numbered in downstream order, with the sequence of presentation being: streams tributary to Lake Michigan - - Little Calumet River Basin (western portion) and Iittle Calumet River Basin (eastern portion); and streams in the Illinois River Basin -- Kankakee River, Des Plaines River, Chicago River, Hickory Creek, Du Page River, Mazon River, and Fox River basins. Each gaging station carries its number on figures 1 and 2 , in the station descriptions, in table 1 , and on the discharge hydrographs, figures 3.-15. The same numbering system is continued in the next section of the report, "Summary of Floods Stages and Discharges", where four miscellaneous sites (No's $1,9,43$ and 47) are included also. These miscellaneous peak-discharge sites account for the apparent gap in numbers in this section of the report. 
(2) Hart ditch at Munster, Ind.

Location.--Lat $41^{\circ} 33^{\prime} 35^{\prime \prime}$, long. $87^{\circ} 28^{\prime} 50^{\prime \prime}$, in $N_{\frac{1}{2}} \mathrm{sec} .20, \mathrm{~T}$. 36 N., R. 9 W., on left bank at city limits of Munster, a quarter of a mile downstream from U. S. Highway 6 and 0.4 mile upstream from mouth. Datum of gage is $591.21 \mathrm{ft}$ above mean sea level, datum of 1929.

Drainage area. - -69.2 sq $\mathrm{mi}$ (revised).

Gage-height record.--Water-stage recorder graph.

Discharge record. - Stage-discharge relation defined by currentmeter measurements. A backwater 10op curve was used for the period $11 \mathrm{p} . \mathrm{m}$. Oct. 10 to oct. 23.

Maxima.--October 1954: Discharge, 2,600 cfs 5 to.10 a.m. Oct. 11; gage height, $7.83 \mathrm{ft} 4$ to $8 \mathrm{p.m}$. Oct. 11 .

1942 to September 1954: Discharge, 2,490 cfs Apr. 6, 1947; gage height, $7.23 \mathrm{ft}$ Mar. 15, 1944.

Remarks. - Hart ditch is tributary to Little Calumet River. At this point low flow of Little Calumet River runs west into Calumet Sag Channel or into Lake Michigan through Calumet River; flood flow at times runs east into channel storage or through Burns ditch to Lake Michigan.

\section{(3) Thorn Creek at Glenwood, III.}

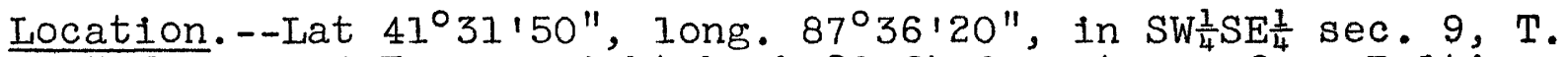
35 N., R. 14 E., on right bank 20 ft downstream from Baltimore \& Ohio Chicago Terminal Railroad bridge, $0.7 \mathrm{mile}$ north of Chicago Heights, 0.8 mile south of Glenwood, and 1 mile upstream from Deer Creek. Datum of gage is $610.97 \mathrm{ft}$ above mean sea level, datum of 1929.

Drainage area. $--25.4 \mathrm{sq} \mathrm{mi}$.

Gage-height record.--Water-stage recorder graph.

Discharge record.--Stage-discharge relation defined by currentmeter measurements.

Maxima.--October 1954: Discharge, $916 \mathrm{cfs} 10$ to $11 \mathrm{p.m}$. Oct. 10 (gage height, $9.88 \mathrm{ft}$ ).

1949 to September 1954: Discharge, 848 cfs June 10, 1953 (gage height, $9.63 \mathrm{ft}$ ).

Remarks.--Figures of discharge include about 6 cfs pumped from ground-water sources for municipal supply of Chicago Heights and undetermined amount of ground-water pumpage for industrial use above station. Undetermined amount of pumpage diverted by commercial livestock feeding pens above station. 


\section{(4) Deer Creek near Chicago Heights, III.}

Location.--Lat $41^{\circ} 31^{\prime} 15^{\prime \prime}$, long. $87^{\circ} 35^{\prime} 25^{\prime \prime}, 0.1 \mathrm{mlle}$ west of center of sec. 14, T. 35 N., R. 14 E., on left bank at bridge on Joe Orr Road, $0.4 \mathrm{mlle}$ east of Cottage Grove Avenue, $1 \mathrm{mlle}$ north of U. S. Highway $30,1.5$ miles northeast of Chicago Helghts, and $1.6 \mathrm{mlles}$ west of Torrence Avenue. Datum of gage is $615.95 \mathrm{ft}$ above mean sea level, datum of 1929 .

Drainage area. $--24.4 \mathrm{sq} \mathrm{mi}$.

Gage-helght record.--Water-stage recorder graph. Discharge record.--Stage-discharge relation defined by currentmeter measurements. Shifting-control method used at times. Maxima.--october 1954: Discharge, 637 cfs 11 a.m. Oct. 11 (gage height, $11.19 \mathrm{ft}$ ).

1948 to September 1954: Discharge, $663 \mathrm{cfs}$ May 10 or 11, 1948 (gage height, $11.52 \mathrm{ft}$, from floodmark).

Remarks.--Undetermined amount of flow diverted for irrigation above station.

(5) Butterfield Creek at Flossmoor, IIl.

Location.--Lat $41^{\circ} 32^{\prime} 25^{\prime \prime}$, long. $87^{\circ} 38^{\prime} 55^{\prime \prime}$, in $N E \frac{1}{4} N T^{\frac{1}{4}}$ sẹc. 8, T. $35 \mathrm{~N} .$, R. 14 E., on left bank at Riegle Road Bridge at Homewood city limits, 0.1 mile north of Holbrook Road and three-quarters of a mile east of Flossmoor. Datum of gage is $616.80 \mathrm{ft}$ above mean sea level, datum of 1929.

Drainage area. --22.9 $\mathrm{sq} \mathrm{ml}$.

Gage-he1ght record. - Water-stage recorder graph.

Discharge record.--Stage-discharge relation defined by currentmeter measurements below $540 \mathrm{cfs}$ and extended to peak stage by logarithmic plotting.

Maxima.--October 1954: Discharge, 788 cfs 12 p.m. Oct. 10 (gage he1ght, $10.92 \mathrm{ft}$ ).

1948 to September 1954: D1scharge, 683 cfs Mar. 19, 1948, May 10 or 11, 1948 (gage helghts, 10.29 and $10.28 \mathrm{ft}$, from floodmarks).

(6) Lansing ditch near Lansing, Ill:

Location.--Lat $41^{\circ} 31^{\prime} 40^{\prime \prime}$, long. $87^{\circ} 31^{\prime} 45^{\prime \prime}$, at north boundary of sec. 17, T. 35 N., R. 15 E., on right bank at upstream side of bridge on farm road, 0.2 mile west of Indiana state line, 0.5 mile east of Burnham Avenue, and 2 miles south of Lansing.

Datum of gage is 607.16 ft above mean sea level, datum of 1929 . Drainage area.--8.3 $\mathrm{sq} \mathrm{mi}$, approximately. Gage-helght record. - Water-stage recorder graph. Discharge record.--Stage-discharge relation defined by currentmeter measurements. Shifting-control method used at times. 
(6) Lansing ditch near Lansing, Ill.--Continued

Maxima.--October 1954: Discharge, 302 cfs 4 p.m. Oct. 11 (gage height, $10.18 \mathrm{ft}$ ).

1948 to September 1954: Discharge, 461 cfs May 10 or 11, 1948. (gage height, $9.24 \mathrm{ft}$, from floodmark).

Remarks.--Undetermined amount of flow diverted for irrigation above station. Some merging of basins and interbasin flow during flood period.

\section{(7) North Creek near Lansing, Ill.}

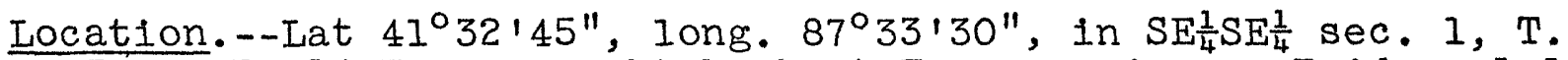
35 N., R. 14 E., on right bank at Torrence Avenue Bridge, 1.1 miles south of Lansing and 2.7 miles north of U. S. Highway 30 . Datum of gage is 599.29 ft above mean sea level, datum of 1929. Drainage area. --18.2 $\mathrm{sq} \mathrm{mi}$.

Gage-helght record.--Water-stage recorder graph.

Discharge record.--Stage-discharge relation defined by currentmeter measurements. Shifting-control method used at times. Maxima.--October 1954: Discharge, $692 \mathrm{cfs} 10$ to $12 \mathrm{p.m}$. Oct. 10 (gage height, $8.96 \mathrm{ft}$ ).

1948 to September 1954: Discharge, $730 \mathrm{cfs}$ (revised) Mar. 20, 1948 (gage height, $8.51 \mathrm{ft}$, revised, from floodmark).

(8) Thorn Creek at Thornton, III.

Location.--Lat $41^{\circ} 34^{\prime} 0^{\prime \prime}$, long. $87^{\circ} 36^{\prime} 30^{\prime \prime}$, near center of $N \frac{1}{2}$ sec. 34, T. 36 N., R. 14 E., on right bank at downstream side of Ridge Road Bridge in Thornton, 1 mile downstream from North Creek and $1 \frac{1}{2}$ miles upstream from Grand Trunk Rallway. Datum of gage is $586.43 \mathrm{ft}$ above mean sea level, datum of 1929 . Drainage area. --106 $\mathrm{sq} \mathrm{mi}$.

Gage-height record.--Water-stage recorder graph. Discharge record.--Stage-discharge relation defined by currentmeter measurements. Shifting-control method used at times. Maxima.--October 1954: Discharge, 3,370 cfs 9 a.m. Oct. 11 (gage height, $14.70 \mathrm{ft}$ ).

1948 to September 1954: Discharge, 4,040 cfs Mar. 20, 1948 (gage height, $14.08 \mathrm{ft}$, from floodmark).

Flood of Apr. 5, 1947, reached a stage of $14.34 \mathrm{ft}$, from floodmark (discharge, 4,200 cfs).

Remarks.--Some diurnal fluctuation caused by pumping operations above station. Figures of discharge include about $6 \mathrm{cfs}$ pumped from ground-water sources for municipal supply of Chicago Heights and undetermined amount of ground-water pumpage for industrial use above station. 
(10) Little Calumet River at South Holland, IIl.

Location.--Lat $41^{\circ} 36^{\prime} 05^{\prime \prime}$, Iong. $87^{\circ} 34^{\prime} 38^{\prime \prime}$, in SW $\frac{1}{4}$ SW $\frac{1}{4}$ sec. 13, T. 36 N., R. 14 E., on right bank at downstream side of bridge on U. S. Highway $6,0.6$ mile downstream from Thorn Creek and 1.6 miles east of South Holland, and 4.1 miles upstream from former gaging station at Harvey. Auxiliary gage at Dixmoor, 6.1 miles downstream. Datum of gages is $575.00 \mathrm{ft}$ above mean sea level.

Gage-he1ght record.--Water-stage recorder graphs from base and auxiliary gages.

Discharge record.--Computed by constant-fall method. Stage-falldischarge relations defined by current-meter measurements. Maxima.--October 1954: Discharge, 4,210 cfs 8 to 9 p.m. Oct. Il (gage helght, $19.39 \mathrm{ft}$ ).

1947 to September 1954: Discharge, 3,810 cfs May 11, 1948 (gage height, $17.33 \mathrm{ft}$ ).

Flood of Apr. 6, 1947, reached a stage of $19.24 \mathrm{ft}$, from floodmark (discharge, 4,760 cfs).

Remarks. - Flow from about $330 \mathrm{sq} \mathrm{mi}$ of upper Little Calumet River basin above a point in Gary, Indiana, is diverted to Lake. Michigan by Burns ditch (see p. 14).

\section{(11) Midlothian Creek at Oak Forest, IIl.}

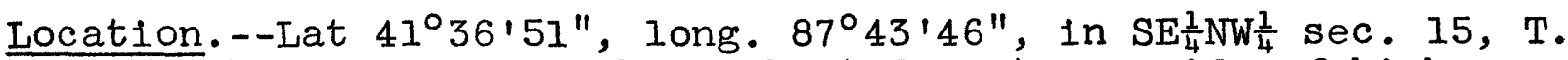
36 N., R. 13 E., on right bank at downstream side of highway bridge in Oak Forest, 4.4 miles upstream from mouth. Datum of gage is $620.41 \mathrm{ft}$ above mean sea level, datum of 1929 (Cook County Highway Department benchmark).

Drainage area. $--12.7 \mathrm{sq} \mathrm{ml}$.

Gage-he1ght record.--Water-stage recorder graph.

Discharge record.--Stage-discharge relation defined by currentmeter measurements. Shifting-control method used at times. Maxima.--October 1954: Discharge, 569 cfs 12 p.m. Oct. 10 (gage he1ght, $8.49 \mathrm{ft}$ ).

1950 to September 1954: Discharge, $384 \mathrm{cfs}$ (revised) June 10, 1953 (gage height, $6.38 \mathrm{ft}$ ).

Remarks.--Diurnal fluctuation at low flow caused by industrial

plants upstream.

(12) Wolf Lake at Chicago, III.

Location.--Lat $41^{\circ} 40^{\prime} 00^{\prime \prime}$, long. $87^{\circ} 32 ' 15^{\prime \prime}$, in SW $\frac{1}{4}$ sec. 29, T. 37 N., R. 15 E., at outlet on west shore in Chicago. Datum of gage is $580.45 \mathrm{ft}$ above mean sea level, datum of 1929 (Cook County Highway Department benchmark). Gage-height record.--Water-stage recorder graph. Maxima.--October 1954: Gage helght, $3.00 \mathrm{ft} 5$ p.m. Oct. 11 to 7 a.m. Oct. 12 .

1939 to September 1954: Hourly mean gage helght, $2.32 \mathrm{ft}$ June 27, 1952 .

Remarks.--Hourly mean values used to determine extremes in order to dampen effects of wind action. 
(13) Deep River at Lake George Outlet at Hobart, Ind.

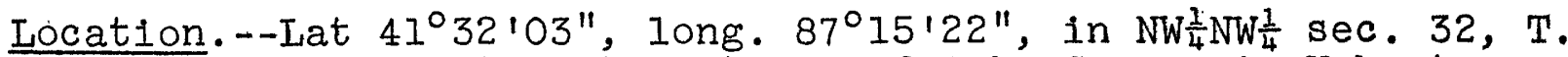
36 N., R. 7 W., at northeast end of lake George in Hobart, an eighth of a mile upstream from Duck Creek. Datum of gage is $600.00 \mathrm{ft}$ above mean sea level, datum of 1929. Drainage area. - -125 sq mi (revised). Gage-height record.--Water-stage recorder graph. Discharge record.--Stage-discharge relation defined by currentmeter measurements. Shifting-control method used at times. Maxima.--October 1954: Discharge, 3,880 cfs 1:30 to 2 p.m. Oct. 11 (gage height, $7.68 \mathrm{ft}$ ).

1947 to September 1954: Discharge, 2,740 cfs May 11, 1948 (gage height, $5.86 \mathrm{ft}$ ).

\section{(14) Burns ditch at Gary, Ind.}

Location.--Lat $41^{\circ} 34^{\prime} 25^{\prime \prime}$, long. $87^{\circ} 17^{\prime} 15^{\prime \prime}$, in $\mathrm{N}^{\frac{1}{2}} \mathrm{sec} .13$, T. 36 N., R. 8 W., near center of span on downstream side of bridge on Central Avenue, 0.5 mile east of Gary and $1 \frac{1}{4}$ miles downstream from Deep River. Altitude of gage is $577 \mathrm{ft}$ (from topographic map).

Drainage area.--About $160 \mathrm{sq} \mathrm{mi}$ (revised, approximate for flood f'lows).

Gage-height record.--Graph drawn on basis of twice-dally wireweight gage readings except during peak when gage was read every two hours.

Discharge record.--Stage-discharge relation defined by currentmeter measurements. Shifting-control method used at times. Maxima.--October 1954: Discharge, 3,430 cfs 2 to 6 p.m. Oct. 11; gage height, $15.90 \mathrm{ft} 1$ to $5 \mathrm{a} . \mathrm{m}$. Oct. 12, from graph based on gage readings.

1943 to September 1954: Discharge, 2,660 cfs May 11, 1948; gage helght, 16.44 ft Mar. 16, 1944, from graph based on gage readings.

Remarks.--Discharges not published for stages below $6 \mathrm{ft}$. Stagedischarge relation affected by backwater from Lake Michigan.

(15) Little Calumet River at Porter, Ind.

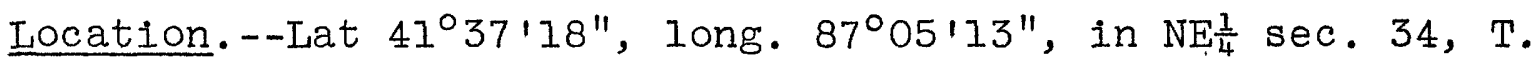
37 N., R. 6 W., near center of span on downstream side of highway bridge, three-quarters of a mile northwest of Porter and 4.5 miles upstream from Salt Creek. Datum of gage is $603.48 \mathrm{ft}$ above mean sea level, datum of 1929.

Drainage area.--62.9 sq $\mathrm{mi}$ (revised).

Gage-height record.--Water-stage recorder graph.

Continued on next page 
(15) Little Calumet River at Porter, Ind.--Continued

Discharge record.--Stage-discharge relation defined by currentmeter measurements. Shifting-control method used at times. Maxima.--October 1954: Discharge, 3,110 cfs 9 p.m. Oct. I0 (gage height, $11.66 \mathrm{ft}$ ).

1945 to September 1954: Discharge, 2,440 cfs June 28, 1945 (gage height, $9.88 \mathrm{ft}$, from graph based on gage readings).

\section{(16) Salt Creek near McCool, Ind.}

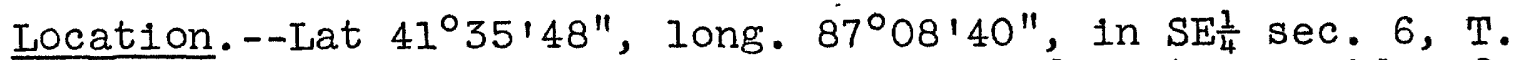
36 N., R. 6 W., near center of span on downstream side of highway bridge, just downstream from Michigan Central Railroad bridge, $1 \frac{1}{4}$ miles north of McCool and 1.5 miles upstream from Little Calumet River. Altitude of gage is $595 \mathrm{ft}$ (from topographic map).

Drainage area.--78.7 sq mi (revised).

Gage-height record.--Graph drawn on basis of floodmark and twicedally wire-weight gage readings.

Discharge record.--Stage-discharge relation defined by currentmeter measurements. Shifting-control method used at times. Maxima.--October 1954: Discharge, 3,180 cfs 6 a.m. Oct. I1 (gage he1ght, $14.12 \mathrm{ft}$ ).

1945 to September 1954: Discharge, 1,910 cfs (revised) May 11, 1948 (gage height, $12.3 \mathrm{ft}$ ).

\section{(17) Kankakee River near North Liberty, Ind.}

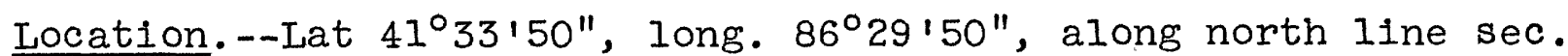
23 , T. 36 N., R. 1 W., near center of span on downstream side of county highway bridge at St. Joseph-La Porte County line, 4 miles northwest of North Liberty. Datum of gage is $680.04 \mathrm{ft}$ above mean sea level, datum of 1929 (levels by Indiana Flood Control and Water Resources Commission).

Drainage area. --152 sq mi (revised).

Gage-helght record. -Graph drawn on basis of once-daily wireweight gage readings. No gage-height record oct. $3,10,17$, 24,31 , Nov. 7, 11, 14, 21, 25, and 28 .

Discharge record.--Stage-discharge relation defined by currentmeter measurements. Shifting-control method used at times. Discharge for periods: of no gage-height record estimated on basis of records for downstream stations.

Maxima.--October 1954: Discharge, 686 cfs 3 to 4 p.m. Oct. 10; gage helght, $8.64 \mathrm{ft} 12 \mathrm{~m}$. Oct. 12, from graph based on gage readings.

1951 to September 1954: Discharge, 680 cfs Nov. 14, 1951 (gage helght, $6.97 \mathrm{ft}$, from graph based on gage readings). 
(18) Kankakee River at Davis, Ind.

Location.--Lat $41^{\circ} 24^{\prime}$, long. $86^{\circ} 42^{\prime}$, in sec. 13, T. 34 N., R. $3 \mathrm{~W}$., on left bank at downstream side of bridge on U. S. Highway 30 at Davis, half a mile downstream from Mill Creek and 4 miles east of Hanna. Datum of gage is 664.68 ft above mean sea level, datum of 1929.

Drainage area. - $-508 \mathrm{sq} \mathrm{mi}$ (revised).

Gage-height record.--Water-stage recorder graph. Discharge record. - Stage-discharge relation defined by currentmeter measurements. Shifting-control method used at times. Maxima.--October 1954: Discharge, 1,620 cfs 10 p.m. Oct. I6 to 6 p.m. Oct. 18 (gage height, $11.76 \mathrm{ft}$ ).

1925-29, 1931 to September 1954: Discharge observed, about $1,700 \mathrm{cfs}$ Dec. 15, 1927 (gage height, $9.50 \mathrm{ft}$, site and datum then in use), from rating curve extended above $520 \mathrm{cfs}$.

\section{(19) Yellow River at Plymouth, Ind.}

Location.--Lat $41^{\circ} 20^{\prime}$, long. $86^{\circ} 18^{\prime}$, in sec. 4, T. 33 N., R. 2 E., near center of span at la Porte street footbridge in Plymouth, half a mile downstream from Baker ditch and 7 miles upstream from Wolf Creek. Datum of gage is $764.78 \mathrm{ft}$ above mean sea level, datum of 1929.

Drainage area. --284 sq mi (revised).

Gage-height record.--Graph drawn on basis of twice-daily wireweight gage readings except oct. 12-15 when the gage was read approximately every thirty minutes. No gage-height record Nov . 6, 7, 14 .

Discharge record.--Stage-discharge relation defined by currentmeter measurements. Shifting-control method used at times. Discharge for Nov. 6, 7, 14 estimated on basis of records for Yellow River at Knox.

Maxima.--October 1954: Discharge, 5,390 cf's 8 p.m. Oct. 12 to 4 a.m. Oct. 13 (gage height, $17.13 \mathrm{ft}$ ).

1948 to September 1954: Discharge, 3,230 cf's July 12, 1951 (gage height, $13.39 \mathrm{ft}$ ).

\section{(20) Yellow River at Knox, Ind.}

Location.--Lat $41^{\circ} 18^{\prime}$, long. $86^{\circ} 37^{\prime}$, in sec. 14, T. 33 N., R. 2 W., on right bank $4 \odot$ ft upstream from bridge on U. S. Highway 35 in Knox, $1 \frac{1}{2}$ miles downstream from Eagle Creek and 9 miles upstream from mouth. Datum of gage is $679.93 \mathrm{ft}$ above mean sea level, datum of 1929 (Lafayette supplementary adjustment of 1951.

Drainage area.--425 sq mi (revised). Gage-height record.--Water-stage recorder graph. 
(20) Yellow River at Knox, Ind.--Continued

Discharge record.--Stage-discharge relation defined by currentmeter measurements. Shifting-control method used at times. Maxima.--October 1954: Discharge, 5,660 cfs 10 p.m. Oct. 15, 4 a.m. Oct. 16 (gage height, $13.75 \mathrm{ft}$ ).

1943 to September 1954: Discharge, 3,160 cfs Apr. 7, 1950 (gage height, $10.42 \mathrm{ft}$ ).

(21) Kankakee River at Dunns Bridge, Ind.

Location.--Lat $41^{\circ} 13^{\prime} 17^{\prime \prime}$, long. $86^{\circ} 57^{\prime} 52^{\prime \prime}$, in sec. 15, T. 32 N., R. $5 \mathrm{~W}$., near center of span on upstream side of county highway bridge at Dunns Bridge, $1 \frac{3}{4}$ miles north of Tefft and $3 \frac{1}{2}$ miles upstream from Davis altch. Datum of gage is $649.65 \mathrm{ft}$ above mean sea level, datum of 1929, Lafayette supplementary adjustment of 1951 (levels by Indiana Flood Control and Water Resources Commission).

Drainage area. $-1,308 \mathrm{sq} \mathrm{mi}$ (revised).

Gage-height record.--Graph drawn on basis of twice-dally wirewelght gage readings.

Discharge record.--Stage-discharge relation defined by currentmeter measurements.

Maxima.--October 1954: Discharge, 5,300 cfs 3 to 11 a.m. Oct. 22 (gage helght, $13.20 \mathrm{ft}$ ).

1948 to September 1954: Discharge, 5,200 cfs Apr. 12, 1950 (gage height, $13.08 \mathrm{ft}$ ).

\section{(22) Kankakee River at Shelby, Ind.}

Location.--Iat $41^{\circ} 11^{\prime}$, long. $87^{\circ} 21$ ', in sec. 33, T. 32 N., R. 8 W., on left bank $25 \mathrm{ft}$ downstream from Chicago, Indianapolis \& Loulsville Railway bridge, 1 mile south of Shelby, and 9 miles upstream from Beaver Lake Creek. Datum of gage is $628.13 \mathrm{ft}$ above mean sea level, datum of 1929.

Drainage area. $-1,753 \mathrm{sq} \mathrm{mi}$ (revised).

Gage-height record.--Water-stage recorder graph.

Discharge record.--Stage-discharge relation defined by currentmeter measurements.

Maxima.--October 1954: Discharge, 5,040 cfs $12 \mathrm{~m}$. to $10 \mathrm{p} . \mathrm{m}$. oct. 27 (gage height, $10.60 \mathrm{ft}$ ).

1922 to September 1954: Discharge observed, 7,200 cfs Dec. 21, 1927 (gage helght, $11.40 \mathrm{ft}$, present datum, site then in use), from rating curve extended above 3,000 cfs by gagehelght relation study with that of present site. 
(23) Singleton ditch at Schneider, Ind.

Location.--Lat $41^{\circ} 12^{\prime} 44^{\prime \prime}$, long. $87^{\circ} 26^{\prime} 44^{\prime \prime}$, on line between $\mathrm{NE} \frac{1}{4}$ sec. 21 and NW $\frac{1}{4}$ sec. 22 , T. 32 N., R. 9 W., on left bank about 15 ft upstream from bridge on U. S. Highway 4l, half a mile upstream from Bruce ditch, $1 \frac{1}{2}$ miles downstream from Cedar Creek, and $12 / 3$ miles north of Schneider. Datum of gage is $623.67 \mathrm{ft}$ above mean sea level, datum of 1929.

Drainage area. $--122 \mathrm{sq} \mathrm{mi}$.

Gage-height record.--Water-stage recorder graph. Discharge record.--Stage-discharge relation defined by currentmeter measurements. Shifting-control method used at times. Maxima.--October 1954: Discharge, 953 cfs 10 p.m. Oct. 11 to I a.m. Oct. 12,5 to 11 a.m. Oct. 12 (gage height, $10.10 \mathrm{ft}$ ). 1950 .

1948 to September 1954: Dally discharge, 1,100 cfs Apr. 10,

\section{(24) West Creek near Schneider, Ind.}

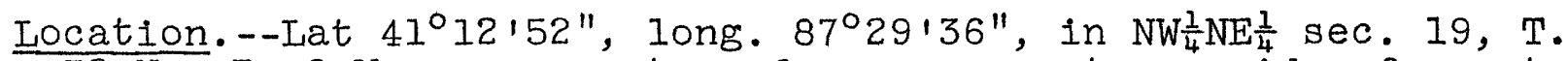
32 N., R. 9 W., near center of span on upstream side of county highway bridge, 1.2 miles upstream from Singleton ditch and $2 \frac{3}{4}$ miles northwest of Schneider. Altitude of gage is $631 \mathrm{ft}$ (by altimeter).

Drainage area. $--54.5 \mathrm{sq} \mathrm{mi}$ (revised).

Gage-height record.--Graph drawn on basis of floodmark and twicedaily wire-weight gage readings.

Discharge record. --Stage-discharge relation defined by currentmeter measurements. Shifting-control method used at times.

Maxima.--October 1954: Discharge, 1,870 cfs 11 p.m. Oct. 10 to 1 a.m. Oct. 11 (gage height, $8.09 \mathrm{ft}$ ).

1948-51, January to September 1954: Discharge, 1,050 cfs Dec. 22, 1949 (gage height, $6.56 \mathrm{ft}$ ).

\section{(25) Singleton ditch at Illinoi, IIl.}

Location.--Lat $41^{\circ} 11^{\prime} 20^{\prime \prime}$, long. $87^{\circ} 31^{\prime} 35^{\prime \prime}$, in SW $\mathrm{I}_{4} \mathrm{NW} \frac{1}{4}$ sec. 8, T. 31 N., R. $15 \mathrm{E}$. , near center of span on downstream side of county highway bridge in Illinoi, beside the Cleveland, Cincinnati, Chicago \& St. Louis Railroad and at Indiana-Illinols state ilne. Datum of gage is 620.33 ft above mean sea level, datum of 1929 . Drainage area. $--219 \mathrm{sq} \cdot \mathrm{mi}$ (revised).

Gage-height record.--Water-stage recorder graph. No gage-height record Nov. 14-22.

Discharge record.--Stage-discharge relation defined by currentmeter measurements. Shifting-control method used at times. Discharge for period Nov. 14-22 estimated on basis of records for stations on nearby streams.

Maxima.--October 1954: Discharge, 2,110 cfs 7 to 8 p.m. Oct. 11 (gage height, $9.81 \mathrm{ft}$ ).

1944 to September 1954: Discharge, 1,850 cfs Apr. 11, 1950 (gage height, $9.26 \mathrm{ft}$ ). 
(26) Kankakee River at Momence, III.

Location.--Lat $41^{\circ} 09^{\prime} 36^{\prime \prime}$, long. $87^{\circ} 40^{\prime} \mathrm{O} 1^{\prime \prime}$, in $\mathrm{NE} \frac{1}{4}$ sec. $24, \mathrm{~T}$. 31 N., R. 13 E., on right bank a quarter of a mile downstream from highway bridge in Momence and $1 \frac{1}{4}$ miles upstream from Tower Creek. Datum of gage is $610.18 \mathrm{ft}$ above mean sea level, datum of 1929.

Drainage area. $-2,340 \mathrm{sq} \mathrm{ml}$, approximately.

Gage-height record. --Water-stage recorder graph.

Discharge record.--Stage-discharge relation defined by currentmeter measurements.

Maxima.--October-November 1954: Discharge, 5,400 cfs 4 a.m. to 11 p.m. Oct. 15 (gage helght, $3.07 \mathrm{ft}$ ).

1905-6, 1914 to September 1954: Discharge, 10,100 cfs Apr. 25, 1950 (gage helght, $5.06 \mathrm{ft}$ ); maximum gage helght observed, $8.09 \mathrm{ft} \mathrm{Jan} .25,1930$ (1ce $\mathrm{Jam}$ ) at site a quarter of a mile upstream.

(27) Kankakee River near Wilmington, Ill.

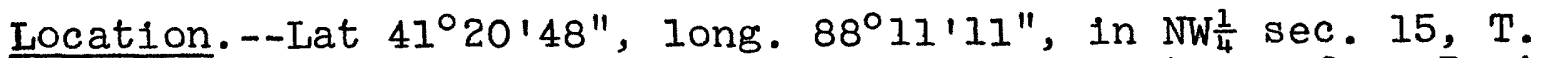
33 N., R. 9 E., on right bank 0.4 mile downstream from Prairie Creek and 5 miles downstream from Wilmington. Datum of gage is $511.10 \mathrm{ft}$ above mean sea level, datum of 1929 .

Drainage area. $--5,250 \mathrm{sq} \mathrm{ml}$, approximately.

Gage-helght record.--Water-stage recorder graph.

Discharge record.--Stage-discharge relation defined by currentmeter measurements.

Maxima.--October, November 1954: Discharge, 10,200 cfs 8 to 9 a.m. Oct. 12 (gage helght, $3.60 \mathrm{ft}$ ).

1935 to September 1954: Discharge, 48,000 cfs May 21, 1943 (gage height, $8.87 \mathrm{ft}$ ); gage height, $11.57 \mathrm{ft}$ Feb. 1, 1949 (1ce jam).

Maximum stage known, $16.73 \mathrm{ft}$ in 1883, 1887.

Remarks. - Slight diurnal fluctuation at low flow caused by power plants above station.

(28) Des Plaines River near Gurnee, III.

Location. --Lat $42^{\circ} 20^{\prime} 40^{\prime \prime}$, long. $87^{\circ} 56^{\prime} 30^{\prime \prime}$, in SW $\frac{1}{4}$ sec. 27, T, 45 N., R. 11 E., on right bank at upstream side of bridge on State Highway $120,600 \mathrm{ft}$ east of intersection of State Highways 120 and $63,2 \frac{1}{2}$ miles southwest of Gurnee, $2 \frac{1}{2}$ miles upstream from Bull Creek, and 6 miles downstream from Mill Creek. Datum of gage is $650.3 \mathrm{ft}$ above mean sea level, datum of 1929 (Corps

of Engineers benchmark). Drainage area. $--215 \mathrm{sq} \mathrm{mI}$. Gage-height record. --Water-stage recorder graph. 
(28) Des Plaines River near Gurnee, Ill.--Continued

Discharge record.--Stage-discharge relation defined by currentmeter measurements.

Maxima.--October 1954: Discharge, 442 cfs 3 to 9 a.m. Oct. 13 (gage height, $4.38 \mathrm{ft}$ ).

1945 to September 1954: Discharge, 2,620 cfs Mar. 21, 1948 (gage height, $9.21 \mathrm{ft}$ ).

\section{(29) Buffalo'Creek near Wheeling, IIl.}

Location.--Lat $42^{\circ} 09^{\prime} 0^{\prime \prime}$, long. $87^{\circ} 57^{\prime} 25^{\prime \prime}$, in $\mathrm{NE} \frac{1}{4} \mathrm{NW} \frac{1}{4} \mathrm{sec} .4$, T. 42 N., R. II E., on left bank at downstream side of highway bridge, i mile downstream from unnamed tributary, and 2.5 miles west of Wheeling. Datum of gage is $658.60 \mathrm{ft}$ above mean sea level, datum of 1929 (Cook County Highway Department benchmark). Drainage area. $--19.4 \mathrm{sq} \mathrm{mi}$.

Gage-height record.--Water-stage recorder graph.

Discharge record. - Stage-discharge relation defined by currentmeter measurements below $80 \mathrm{cfs}$ and extended to peak stage by logarithmic plotting.

Maxima.--October 1954: Discharge, 161 cfs 10:30 p.m. Oct. 10 (gage height, $4.62 \mathrm{ft}$ ).

1952 to September 1954: Discharge, 268 cfs Apr. 25, 1954 (gage height, $5.40 \mathrm{ft}^{\prime}$ ).

\section{(30) Des Plaines River near Des Plaines, Ill.}

Location. --Lat $42^{\circ} 04^{\prime} 55^{\prime \prime}$, long. $87^{\circ} 53^{\prime} 25^{\prime \prime}$, in $\mathrm{SE} \frac{1}{4} \mathrm{SE} \frac{1}{4} \mathrm{sec} .25, \mathrm{~T}$. 42 N., R. 11 E., on right bank $50 \mathrm{ft}$ upstream from dam No. 2 of Cook County Forest Preserve, 0.3 mile downstream from Lake Avenue Bridge, 1.2 miles upstream from Central Road Bridge, and $2 \frac{1}{2}$ miles north of Des Plaines. Datum of gage is $626.31 \mathrm{ft}$ above mean sea level, datum of 1929.

Drainage area. $--374 \mathrm{sq} \mathrm{mi}$.

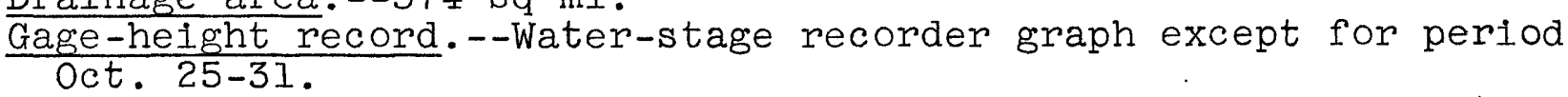

Discharge record.--Stage-discharge relation defined by currentmeter measurements. Discharge for period of no gage-height record 0ct. 25-31 estimated on basis of recorded range in stage and records for station near Gurnee.

Maxima.--October 1954: $:$ Discharge, 1,800 cfs 9 to 11 a.m. Oct. 11 (gage height, $3.25 \mathrm{ft}$ ).

1940 to September 1954: Discharge, 4,040 cfs Apr. 25, 1950 (gage height, $7.78 \mathrm{ft}$ ).

Flood of July 4, 1938, reached a stage of $9.7 \mathrm{ft}$, from floodmark (discharge, 5,500 cfs). 
(31) McDonald Creek near Mt. Prospect, IIl.

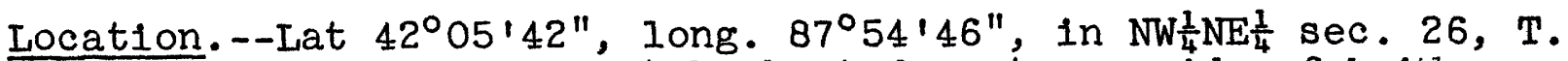
42 N., R. II E., on right bank at downstream side of bridge on McDonald Road, 2 miles upstream from mouth, and 2.5 miles northeast of Mt. Prospect. Datum of gage is $638.12 \mathrm{ft}$ above mean sea leve1, datum of 1929 (Cook County H1ghway Department benchmark).

Drainage area. $--7.52 \mathrm{sq} \mathrm{ml}$.

Gage-helght record.--Water-stage recorder graph.

Discharge record. - Stage-discharge relation defined by currentmeter measurements below $80 \mathrm{cfs}$ and extended to peak stage by logarithmic plotting. Shifting-control method used at times. Maxima.--October 1954: Discharge, 146 cfs 6 a.m. Oct. 11 (gage height, $7.31 \mathrm{ft}$ ).

1952 to September 1954: Discharge, 103 cf's June 3, 1954 (gage height, $6.46 \mathrm{ft}$ ).

\section{(32) Weller Creek at Des Plaines, III.}

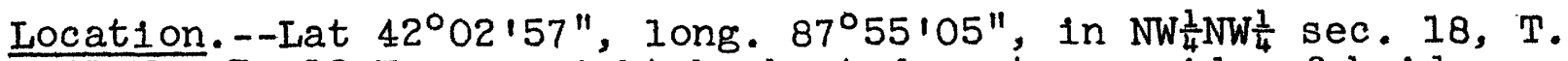
41 N., R. 12 E., on right bank at downstream side of bridge on State Highway 58 in Des Plaines, 2 miles west of U. S. Highway 45 and 3.0 miles upstream from mouth. Datum of gage is 635.02 ft above mean sea level, datum of 1929 (Cook County Highway Department benchmark).

Drainage area. $--13.1 \mathrm{sq} \mathrm{mi}$.

Gage-helght record. - Water-stage recorder graph.

Discharge record.--Stage-discharge relation defined by currentmeter measurements below $160 \mathrm{cfs}$ and extended to peak stage

by logarithmic plotting. Shifting-control method used at times. Maxima.--October 1954: Discharge, 535 cfs 6 p.m. Oct. 10 (gage height, $10.83 \mathrm{ft}$ ).

1950 to September 1954: Discharge, 461 cfs Apr. 25, 1954 (gage height, $9.83 \mathrm{ft}$ ).

(33) Willow Creek near Park Ridge, III.

Location.--Lat $41^{\circ} 59^{\prime} 22^{\prime \prime}$, long. $87^{\circ} 52^{\prime} 24^{\prime \prime}$, in $\mathrm{SW}_{\frac{1}{4}} \mathrm{NE} \frac{1}{4} \mathrm{sec}$. 4, T. 40 N., R. 12 E., on right bank at downstream side of bridge on Byron Street, $0.4 \mathrm{mile}$ south of State Highway $72,1.3$ miles upstream from mouth, and $2 \frac{1}{2}$ miles southwest of Park Ridge. Datum of gage is $620.95 \mathrm{ft}$ above mean sea level, datum of 1929 (Cook County Highway Department benchmark).

Drainage area. $--19.6 \mathrm{sq} \mathrm{mi}$.

Gage-helght record. - Water-stage recorder graph except for the period $12 \mathrm{~m}$. Oct. 5 to $10 \mathrm{a.m}$. Oct. 6, for which graph was drawn on basis of recorded range in stage and recorder graph for Weller Creek at Des PIaines. 
(33) Willow Creek near Park Ridge, Ill.--Continued

Discharge record.--Stage-discharge relation defined by currentmeter measurements below 160 cfs and extended to peak stage by logarithmic plotting.

Maxima:--October 1954: Discharge, 382 cfs 6 a.m. oct. 11 (gage he1ght, $8.32 \mathrm{ft}$ ).

1950 to September 1954: D1scharge, 283 cfs Apr. 25, 1954 (gage height, $7.15 \mathrm{ft}$ ).

(34) Salt Creek near Arlington Heights, Ill.

Location.--Lat $42^{\circ} 03^{\prime} 02^{\prime \prime}$, long. $88^{\circ} 00^{\prime} 37^{\prime \prime}$, on north boundary of sec. 17, T. 41 N., R. 11 E., on right bank at downstream side of bridge on State Highway 58, $2 \frac{3}{4}$ miles southwest of Arlington Heights. Datum of gage is $682.22 \mathrm{ft}$ above mean sea level, datum of 1929 (Cook County Highway Department benchmark). Drainage area. $--33.7 \mathrm{sq} \mathrm{mi}$.

Gage-helght record.--Water-stage recorder graph.

Discharge record.--Stage-discharge relation defined by currentmeter measurements.

Maxima.--October 1954: Discharge, $516 \mathrm{cfs} 11$ to 12 p.m. Oct. 10 (gage height, $8.28 \mathrm{ft}$ ).

1950 to September 1954: Discharge, 540 cfs Apr. 25, 1954 (gage height, $8.43 \mathrm{ft}$ ).

(35) Salt Creek at Western Springs, III.

Location. -- Lat $41^{\circ} 49^{\prime} 35^{\prime \prime}$, long. $87^{\circ} 54^{\prime} 00^{\prime \prime}$, on boundary between secs. 31 and 32 , T. 39 N., R. 12 E., on left bank at upstream side of bridge on Wolf Road, in Cook County Forest Preserve, half a mile north of Western Springs and 8.8 miles upstream from mouth. Datum of gage is $624.81 \mathrm{ft}$ above mean sea level, datum of 1929 (Cook County Highway Department benchmark). Drainage area.--122 sq $\mathrm{mi}$.

Gage-height record.--Water-stage recorder graph.

Discharge record.--Stage-discharge relation defined by currentmeter measurements. Shifting-control method used at times. Maxima.--October 1954: Discharge, 1,710 cfs 12 p.m. Oct. 10 to $1 \mathrm{a} . \mathrm{m}$. Oct. 11, $11 \mathrm{a} . \mathrm{m}$. to $12 \mathrm{~m}$. Oct. 11 (gage helght, $8.27 \mathrm{ft}$ ). 1945 to September 1954: Discharge, I,920 cfs Mar. 20, 1948 (gage height, $8.06 \mathrm{ft}^{*}$ ).

Remarks.--Occasional regulation by dam above station. Some diversion for irrigation above station. 
(36) Addison Creek at Bellwood, III.

Location.--Lat $41^{\circ} 52^{\prime} 48^{\prime \prime}$, long. $87^{\circ} 52^{\prime} 07^{\prime \prime}$, in SE $\frac{1}{4}$ sec. 9, T. 39 N., R. 12 E., on right bank at downstream side of bridge on Washington Boulevard in Bellwood, 500 ft upstream from Chicago Great Western Railroad bridge and 3.2 miles upstream from mouth. Datum of gage is $617.65 \mathrm{ft}$ above mean sea level, datum of 1929 (Cook County Highway Department benchmark). Drainage area. $--18.2 \mathrm{sq} \mathrm{mi}$.

Gage-he1ght record.--Water-stage recorder graph. Discharge record.--Stage-discharge relation defined by currentmeter measurements below $190 \mathrm{cfs}$ and extended to peak stage by logarithmic plotting. Shifting-control method used at times. Maxima.--October 1954: Discharge, $598 \mathrm{cfs} 1$ to 2 a.m. Oct. 11 (gage height, $9.48 \mathrm{ft}$ ).

1950 to September 1954: Discharge, 548 cfs Mar. '25, 1954 (gage helght, $6.39 \mathrm{ft}$ ), from rating curve extended above $62 \mathrm{cfs}$ by logarithmic plotting.

(37) Des Plaines River at Riverside, IIl.

Location.--Lat $41^{\circ} 49^{\prime} 20^{\prime \prime}$, long. $87^{\circ} 49^{\prime} 15^{\prime \prime}$, in SW $\frac{1}{4} S W \frac{1}{4}$ sec. 36, T. 39 N., R. 12 E., on left bank 300 ft downstream from Barry Point Road Bridge in Riverside, $200 \mathrm{ft}$ northwest of Riverside-Lyons boundary, $500 \mathrm{ft}$ downstream from Hoffman Dam, 4,000 ft downstream from Salt Creek, and $1 \frac{1}{2}$ miles downstream from Chicago, Burlington \& Quincy Railroad bridge. Datum of gage is 594.68 ft above mean sea level, datum of 1929 . Drainage area. $-635 \mathrm{sq} \mathrm{mi}$.

Gage-height record. --Water-stage recorder graph.

Discharge record.--Stage-discharge relation defined by currentmeter measurements.

Maxima.--October 1954: Discharge, 6,340 cfs 6 p.m. Oct. 11 (gage' helght, $8.15 \mathrm{ft}$ ).

1943 to September 1954: Discharge, 6,510 cfs Mar. 20, 1948

(gage height, $8.28 \mathrm{ft}$ ).

Remarks.--Occasional regulation by gates at Hoffman Dam.

(38) Flag Creek near Willow Springs, Ill.

Location.--Lat $41^{\circ} 44^{\prime} 20^{\prime \prime}$, long. $87^{\circ} 53^{\prime} 48^{\prime \prime}$, in SE $\frac{1}{4} \mathrm{NE} \frac{1}{4}$ sec, 31 , T. 38 N., R. 12 E., on left bank at upstream side of bridge on German Church Road, 1.1 miles northwest of Willow Springs and 2.3 miles upstream from mouth. Datum of gage is $609.64 \mathrm{ft}$ above mean sea level, datum of 1929 (Cook County Highway Department benchmark).

Drainage area. $--16.2 \mathrm{sq} \mathrm{mi}$. Gage-helght record.--Water-stage recorder graph. 
(38) Flag Creek near Willow Springs, Il1.--Continued

Discharge record.--Stage-discharge relation defined by currentmeter measurements. Shifting-control method used at times. Max1ma.--October 1954: Discharge, 1,300 cfs 8 p.m. Oct. 10 (gage height, $6.88 \mathrm{ft}$ ).

1951 to September 1954: Discharge, 770 cfs Mar. 25, 1954 (gage height, $5.42 \mathrm{ft}$ ).

(39) North Branch Chicago River at Deerfield, IIl.

Location.--Lat $42^{\circ} 09^{\prime} 09^{\prime \prime}$, long. $87^{\circ} 49^{\prime} 05^{\prime \prime}$, in $\mathrm{NW} \frac{1}{4} \mathrm{NE} \frac{1}{4}$ sec. 3, T. 42 N., R. 12 E., on left bank at downstream side of bridge on County Line Road, 1.7 miles southeast of Deerfield, and 5.7 miles upstream from Skokie River. Datum of gage 638.88 ft above mean sea level, datum of 1929 (Cook County Highway Department benchmark).

Drainage area. $-20.7 \mathrm{sq} \mathrm{mi}$.

Gage-he1ght record.--Water-stage recorder graph.

Discharge record.--Stage-discharge relation defined by currentmeter measurements.

Maxima.--October 1954: Discharge, 211 cfs 3 to 9 a.m. Oct. 11 (gage height, $9.08 \mathrm{ft}$ ).

1952 to September 1954: Discharge, 247 cf's Mar. 25, 1954 (gage helght, $9.35 \mathrm{ft}$ ).

(40) Skokie River at Lake Forest, Ill.

Location.--Iat $42^{\circ} 13^{\prime} 57^{\prime \prime}$, long. $87^{\circ} 50^{\prime} 41^{\prime \prime}$, in NW/ SW $\frac{1}{4}$ sec. 4, T. 43 N., R. 12 E., on left bank at downstream side of bridge on State Highway 59A at Lake Forest, 12 miles upstream from mouth. Datum of gage is $648.69 \mathrm{ft}$ above mean sea level, datum of 1929. Drainage area. $--12.8 \mathrm{sq} \mathrm{mi}$.

Gage-helght record. - Water-stage recorder graph.

Discharge record.--Stage-discharge relation defined by currentmeter measurements.

Maxima.--October 1954: Discharge, 188 cfs 10 p.m. oct. 10 (gage height, $5.42 \mathrm{ft}$ ).

1951 to September 1954: Discharge, 321 cfs Nov. 13, 1951

(gage height, $7.16 \mathrm{ft}$ ).

Remarks.--Diurnal fluctuation at low flow. 
(41) West Fork of North Branch Chicago RIver at Northbrook, III.

Location.--Lat $42^{\circ} 08^{\prime} 18^{\prime \prime}$, Iong. $87^{\circ} 50^{\prime} 04^{\prime \prime}$, in SW $\frac{1}{4} \mathrm{SE} \frac{1}{4} \mathrm{sec}$. 4, T. 42 N., R. $12 \mathrm{E}$., on left bank at upstream side of bridge on State Highway $68,2.0$ miles northwest of Northbrook, and 7.9 miles above mouth. Datum of gage is $637.98 \mathrm{ft}$ above mean sea level, datum of 1929 (Cook County Highway Department benchmark). Drainage area. $--11.5 \mathrm{sq} \mathrm{ml}$.

Gage-helght record.--Water-stage recorder graph.

Discharge record.--Stage-discharge relation defined by currentmeter measurements. Shifting-control method used at times. Maxima.--October 1954: Discharge, 301 cfs 2 a.m. Oct. I1 (gage height, $8.18 \mathrm{ft}$ ).

1952 to September 1954: Discharge, 411 cfs Mar. 25, 1954 (gage height, $8.56 \mathrm{ft}$ ).

(42) North Branch Chicago River at Niles, IIl.

Location.--Iat $42^{\circ} 00^{\prime} 44^{\prime \prime}$, long. $87^{\circ} 47^{\prime} 45^{\prime \prime}$, in $\mathrm{SW}_{\frac{1}{4}} \mathrm{SE} \frac{1}{4} \mathrm{sec} .30$, T. 41 N., R. 13 E., on right bank at downstream side of bridge on Touhy Avenue in Niles, 3.6 miles downstream from West Fork of North Branch, 7.9 miles upstream from North Shore Channe1, and 15:6 miles upstream from mouth. Datum of gage is $601.99 \mathrm{ft}$ above mean sea level, datum of 1929.

Drainage area. $-102 \mathrm{sq} \mathrm{mi}$.

Gage-helght record.--Water-stage recorder graph.

Discharge record.--Stage-discharge relation defined by currentmeter measurements. Shifting-control method used at times. Maxima.--October 1954: Discharge, 1,700 cfs 3 a.m. Oct. 11 (gage he1ght, $9.01 \mathrm{ft}$ ).

1950 to September 1954: Discharge, 1,510 cfs Apr. 26, 1954 (gage height, $8.56 \mathrm{ft}$ ).

Remarks.--Considerable regulation at low flow.

\section{(44) Tinley Creek near Palos Park, IIl.}

Location.--Lat $41^{\circ} 38^{\prime} 48^{\prime \prime}$, long. $87^{\circ} 45^{\prime} 59^{\prime \prime}$, in $\mathrm{SW} \frac{1}{4} \mathrm{SE} \frac{1}{4} \mathrm{sec} .32, \mathrm{~T}$. 37 N., R. 13 E., on left bank at downstream side of 135 th street Bridge, 1.5 miles west of U.S. Highway $50,1.5$ miles upstream from mouth, and 3 miles southeast of Palos Park. Datum of gage is $607.40 \mathrm{ft}$ above mean sea level, datum of 1929. Drainage area. --11.3 sq: $\mathrm{mi}$. Gage-height record.--Water-stage recorder graph. Discharge record.--Stage-discharge relation defined by currentmeter measurements below $800 \mathrm{cfs}$ and extended to peak stage by logarithmic plotting. Shifting-control method used at times. Maxima.--October 1954: Discharge, 1,120 cfs 7 a.m. Oct. 10 (gage height, $10.30 \mathrm{ft}$ ).

1951 to September 1954: Discharge, 530 cfs June 10, 1953 (gage height, $8.43 \mathrm{ft}$ ). 
(45) Chicago Sanitary and Ship Canal at Lockport, III.

Location.--Lat $41^{\circ} 34^{\prime} 11^{\prime \prime}$, Iong. $88^{\circ} 04^{\prime} 42^{\prime \prime}$, in SW $\frac{1}{4}$ sec. 27, T. 36 N., R. 10 E., at upper end of 9 -foot navigation channel in Des Plaines River at Lockport.

Discharge record.--Total mean daliy discharge includes governmental and private pumpage, inflow from Des Plaines River basin, and diversion from Lake Michigan. This total is obtained by adding the mean daily discharges, based on half-hourly discharge readings at dams, sluice gates, lockages, exciter turbines in operation and main turbines in operation as corrected for vari$a b l e$ efficiencies, and the leakage of lock gates, dams, sluice gates, and turbines not in operation.

Chicago pumpage includes water from Lake Michigan to supply Chicago metropolitan area, water from wells within the main channel drainage area including pumpage to municipalities served by Chicago, and an average of about $136 \mathrm{cfs}$ from agencies not served by Chicago.

Mean net diversion is obtained by deducting from total discharge the Chicago pumpage and inflow from Des Plaines River basin.

Maxima.--October 1954: Total discharge, 24,585 cfs 8:30 p.m. oct. 10.

i900 to September 1954: Total discharge, 24,567 cfs (revised) Mar. 19, 1948.

Remarks.--Records furnished by Sanitary District of Chicago. The Federal permit of June 26, 1930, issued by the Secretary of War, limits the diversion of water from Lake Michigan to an annual average of $1,500 \mathrm{cfs}$, exclusive of pumpage for municipal supplies.

(46) Long Run near Lemont, III.

Location.--Lat $41^{\circ} 38^{\prime} 33^{\prime \prime}$, long. $87^{\circ} 59^{\prime} 57^{\prime \prime}$, in $\mathrm{SW}_{\frac{1}{4}} \mathrm{SE} \frac{1}{4} \mathrm{sec} .32, \mathrm{~T}$. , 37 N., R. II E., on left bank at downstream side of highway bridge, 2 miles south of Lemont and 5.4 miles upstream from mouth. Datum of gage is $637.10 \mathrm{ft}$ above mean sea level, datum of 1929 .

Drainage area. $--20.8 \mathrm{sq} \mathrm{mi}$.

Gage-height record.--Water-stage recorder graph.

Discharge record.--Stage-discharge relation defined by currentmeter measurements below 1,300 cfs and extended to peak stage by logarithmic plotting.

Maxima.--October 1954: Discharge, 3,160 cfs 6 a.m. Oct. 10 (gage he1ght, $9.91 \mathrm{ft}$ ).

1951 to September 1954: Discharge, 1,000 cfs (revised) June 13, 1952 (gage height, 8.18 ft). 
(48) Hickory Creek at Joliet, III.

Location.--Lat $41^{\circ} 31^{\prime} 10^{\prime \prime}$, 1ong. $88^{\circ} 04^{\prime} 10^{\prime \prime}$, in SW $\frac{1}{4} \mathrm{NE} \frac{1}{4} \mathrm{sec}$. 15, T. 35 N., R. 10 E., on right bank at Third Avenue in Joliet, 0.25 mile downstream from Spring Creek and $1 \frac{3}{4}$ miles upstream from mouth. Datum of gage is $527.00 \mathrm{ft}$ above mean level, datum of 1929.

Drainage area.--107 sq $\mathrm{mi}$.

Gage-helght record.--Water-stage recorder graph except for period 9 a.m. Oct. 11 to $3: 30$ p.m. Oct. 12, for which graph was drawn on basis of recorded range in stage and slope of adjoining graph.

Discharge record.--Stage-discharge relation defined by currentmeter measurements.

Maxima.--October 1954:. Discharge, 8,130 cfs 2 a.m. Oct. 11 (gage height, $9.82 \mathrm{ft}$ ).

1944 to September 1954: Discharge, 10,200 cfs Apr. 5, 1947 (gage height, $10.68 \mathrm{ft}$ ).

\section{(49) Du Page River at Troy, IIl.}

Location.--Lat $41^{\circ} 31^{\prime} 20^{\prime \prime}$, Iong. $88^{\circ} 11^{\prime} 35^{\prime \prime}$, In $\mathrm{SE} \frac{1}{4} \mathrm{SW} \frac{1}{4}$ sec. 10, T. 35 N., R. 9 E., on left bank at Troy (formerly known as Grinton), $400 \mathrm{ft}$ upstream from U. S. Highway 52 and 3.8 miles downstream from Liliy Cache Creek. Datum of gage is 564.62 ft above mean sea level, datum of 1929 (Illinois Division of Waterways benchmark).

Drainage area. $--325 \mathrm{sq} \mathrm{mi}$.

Gage-helght record.--Water-stage recorder graph.

Discharge record.--Stage-discharge relation defined by currentmeter measurements.

Maxima.--October 1954: Discharge, 12,000 cfs 8 a.m. Oct. 11 (gage height, $11.06 \mathrm{ft}$ ).

1940 to September 1954: Discharge, 11,000 cf's Mar. 19, 1948 (gage helght, $10.10 \mathrm{ft}$ ).

(50) Mazon River near Coal City, IIl.

Location.--Lat $41^{\circ} 17^{\prime} 10^{\prime \prime}$, long. $88^{\circ} 21^{\prime} 35^{\prime \prime}$, in SW $\frac{1}{4} S W \frac{1}{4}$ sec. 31, T. 33 N., R. 8 E., on right bank at downstream side of bridge on State Highway 113S, a quarter of a mile downstream from Johnny Run and 4 miles west of Coal City. Datum of gage is $527.41 \mathrm{ft}$ ahove mean sea level, datum of 1929.

Drainage area. $--470 \mathrm{sq} \mathrm{mi}$.

Gage-helght record.--Water-stage recorder graph. 
(50) Mazon River near Coal City, III.--Continued

Discharge record.--Stage-discharge relation defined by currentmeter measurements.

Maxima.--October 1954: Discharge, 707 cfs 3 p.m., 6:30 p.m. Oct. II (gage height, $4.41 \mathrm{ft}$ ).

1939 to September 1954: Discharge, 17,300 cfs Apr. 25, 1950 (gage he1ght, $18.50 \mathrm{ft}$ ).

Maximum stage known, about 21 ft Aug. 8, 1924.

\section{(51) Illinols River at Marseilles, IIl.}

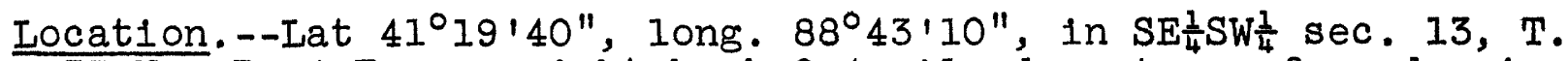
33 N., R. 4 E., on right bank 0.4 mile downstream from dam in Marseilles, 6.9 miles upstream from Fox River, and at mile 246.6. Datum of gage is $462.91 \mathrm{ft}$ above mean sea level, datum of 1929.

Drainage area.--7,640 sq m1, approximately. Since Jan. 17, 1900, flow has included diversion from Lake Michigan through Chicago Sanitary and Ship Canal.

Gage-height record. --Water-stage recorder graph.

Discharge record. - Stage-discharge relation defined by currentmeter measurements.

Maxima:--October 1954: Discharge, 56,600 cfs 7 a.m. Oct. 12 (gage height, $11.39 \mathrm{ft})$.

1919 to September 1954: Discharge, 83,300 cfs Apr. 26, 1950 (gage height, $14.91 \mathrm{ft}$ ).

A stage of $25.4 \mathrm{ft}$ (ice $\mathrm{jam}$ ) occurred at present site on Jan. 21, 1916.

Remarks.--Figures of dally discharge include flow through navigation locks. Flow regulated by power plants and navigation dam above station.

(52) Fox River at Algonquin, III.

Location.--Lat $42^{\circ} 09^{\prime} 59^{\prime \prime}$, long. $88^{\circ} 17^{\prime} 25^{\prime \prime}$, in NW/ sec. 34, T. 43 N., R. 8 E., on right bank 20 ft upstream from Chicago street Bridge at Algonquin and $400 \mathrm{ft}$ upstream from Crystal Lake outlet. Datum of gage is $729.48 \mathrm{ft}$ above mean sea level, datum of 1929.

Drainage area. $--1,364 \mathrm{sq} \mathrm{mi}$.

Gage-height record. --Water-stage recorder graph, except Oct. 26, 28, for which graph was drawn based on fragmentary record.

Discharge record.--Stage-discharge relation defined by currentmeter measurements.

1915 to September 1954: Discharge, 5,850 cfs Apr. 1, 2, 1916; gage helght, $4.50 \mathrm{ft}$ Apr. 1, 1916, from graph based on gage readings.

Remarks.--Flow occasionally regulated by dam near McHenry, 16 miles above station, and occasionally affected by wind action on Fox chain of lakes. 
(53) Poplar Creek at Elgin, IIl.

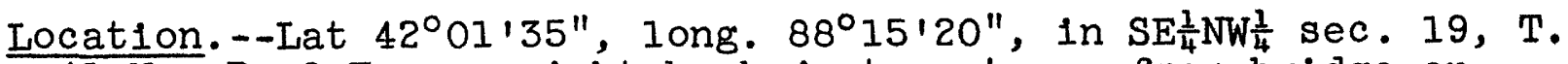
41 N., R. 9 E., on right bank just upstream from bridge on

U. S. Highway 20 in Elgin and 2 miles upstream from mouth.

Datum of gage is $715.91 \mathrm{ft}$ above mean sea level, datum of 1929 . Drainage area. $--35.8 \mathrm{sq} \mathrm{mi}$.

Gage-he1ght record.--Water-stage recorder graph. Discharge record.--Stage-discharge relation defined by currentmeter measurements.

Maxima.--October 1954: D1scharge, 291 cfs 12 p.m. Oct. 10 (gage he1ght, $3.72 \mathrm{ft}$ ).

1951 to September 1954 (revised): Discharge, 310 cfs Apr. 25, 1954 (gage he1ght, $3.83 \mathrm{ft}$ ).

(54) Fox River at Dayton, III.

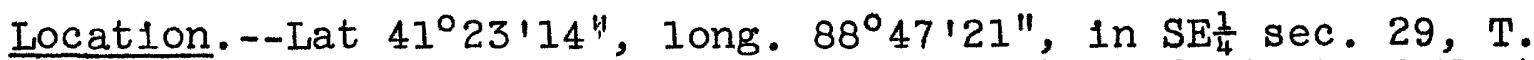
34 N., R. 4 E., on right bank in tallwater of plant of North Counties Hydro-Electric Co. at Dayton, 5.6 miles upstream from mouth. Datum of gage is $462.30 \mathrm{ft}$ above mean sea level, datum of 1929.

Drainage area. $--2,570 \mathrm{sq} \mathrm{mi}$.

Gage-height record.--Water-stage recorder graph.

Discharge record. - Stage-discharge relation defined by currentmeter measurements below $15,000 \mathrm{cfs}$ and by computation of peak flow over dam.

Maxima.--October 1954: Discharge, 47,100 cfs 3:30 p.m. Oct. 11 (gage height, $24.63 \mathrm{ft}$ ).

1925 to September 1954: Discharge, 29,000 cfs Mar. 19, 1948 (gage helght, $19.65 \mathrm{ft}$ ); gage he1ght, $32.04 \mathrm{ft}$ Jan. 30 , 1952 (ice Jam).

Remarks.--Low flow regulated by powerplant above station. 
Table 1.--Daily and monthly discharge, in cubic feet per second, and runoff, in inches, at gaging stations

\begin{tabular}{|c|c|c|c|c|c|c|c|c|c|}
\hline \multirow{2}{*}{$\begin{array}{l}\text { Oct. } \\
1954\end{array}$} & \multicolumn{9}{|c|}{ Station number } \\
\hline & (2) & (3) & (4) & (5) & $(6)$ & $(7)$ & $(8)$ & $(10)$ & (11) \\
\hline $\begin{array}{l}1 \\
2 \\
3 \\
4 \\
5\end{array}$ & $\begin{array}{l}8.0 \\
6.4 \\
9.6 \\
8.0 \\
14\end{array}$ & $\begin{array}{l}19 \\
17 \\
18 \\
21 \\
36\end{array}$ & $\begin{array}{r}0.3 \\
.3 \\
.3 \\
.3 \\
.6\end{array}$ & $\begin{array}{l}1.7 \\
1.6 \\
1.9 \\
2.4 \\
5.4\end{array}$ & $\begin{array}{r}0.8 \\
.8 \\
.9 \\
1.0 \\
3.0\end{array}$ & $\begin{array}{r}0.5 \\
.3 \\
.4 \\
.6 \\
1.6\end{array}$ & $\begin{array}{l}25 \\
22 \\
28 \\
28 \\
59\end{array}$ & $\begin{array}{l}37 \\
31 \\
77 \\
78 \\
67\end{array}$ & $\begin{array}{l}1.0 \\
1.0 \\
5.3 \\
2.8 \\
12\end{array}$ \\
\hline $\begin{array}{r}6 \\
7 \\
8 \\
9 \\
10\end{array}$ & $\begin{array}{c}14 \\
11 \\
9.5 \\
10 \\
1,320\end{array}$ & $\begin{array}{r}22 \\
19 \\
19 \\
23 \\
727\end{array}$ & $\begin{array}{r}1.0 \\
.9 \\
.7 \\
1.1 \\
323\end{array}$ & $\begin{array}{r}3.0 \\
1.7 \\
1.4 \\
2.8 \\
492\end{array}$ & $\begin{array}{r}1.8 \\
1.1 \\
1.0 \\
1.8 \\
171\end{array}$ & $\begin{array}{r}2.7 \\
1.2 \\
.7 \\
.8\end{array}$ & $\begin{array}{r}42 \\
33 \\
30 \\
31 \\
1,260\end{array}$ & $\begin{array}{r}90 \\
69 \\
55 \\
58 \\
1,930\end{array}$ & $\begin{array}{r}12 \\
6.1 \\
3.3 \\
7.9 \\
427\end{array}$ \\
\hline $\begin{array}{l}11 \\
12 \\
13 \\
14 \\
15\end{array}$ & $\begin{array}{r}2,570 \\
1,780 \\
763 \\
504 \\
389\end{array}$ & $\begin{array}{r}682 \\
243 \\
96 \\
60 \\
56\end{array}$ & $\begin{array}{r}594 \\
316 \\
129 \\
75 \\
72\end{array}$ & $\begin{array}{r}608 \\
253 \\
116 \\
87 \\
75\end{array}$ & $\begin{array}{r}293 \\
282 \\
205 \\
101 \\
63\end{array}$ & $\begin{array}{l}555 \\
484 \\
397 \\
282 \\
180\end{array}$ & $\begin{array}{r}3,140 \\
2,090 \\
1,110 \\
717 \\
583\end{array}$ & $\begin{array}{l}3,940 \\
3,850 \\
2,650 \\
1,510 \\
1,030\end{array}$ & $\begin{array}{l}448 \\
325 \\
232 \\
167 \\
107\end{array}$ \\
\hline $\begin{array}{l}16 \\
17 \\
18 \\
19 \\
20\end{array}$ & $\begin{array}{r}256 \\
178 \\
140 \\
117 \\
94\end{array}$ & $\begin{array}{l}54 \\
44 \\
40 \\
39 \\
34\end{array}$ & $\begin{array}{l}44 \\
32 \\
24 \\
20 \\
16\end{array}$ & $\begin{array}{l}59 \\
49 \\
39 \\
35 \\
30\end{array}$ & $\begin{array}{l}39 \\
25 \\
18 \\
15 \\
11\end{array}$ & $\begin{array}{l}97 \\
64 \\
45 \\
38 \\
33\end{array}$ & $\begin{array}{l}416 \\
295 \\
206 \\
156 \\
124\end{array}$ & $\begin{array}{l}762 \\
555 \\
454 \\
399 \\
353\end{array}$ & $\begin{array}{l}76 \\
59 \\
46 \\
39 \\
33\end{array}$ \\
\hline $\begin{array}{l}21 \\
22 \\
23 \\
24 \\
25\end{array}$ & $\begin{array}{l}77 \\
66 \\
56 \\
51 \\
45\end{array}$ & $\begin{array}{l}30 \\
30 \\
30 \\
29 \\
28\end{array}$ & $\begin{array}{l}13 \\
11 \\
9.8 \\
8.2 \\
7.4\end{array}$ & $\begin{array}{l}26 \\
22 \\
20 \\
16 \\
14\end{array}$ & $\begin{array}{l}9.3 \\
7.8 \\
6.7 \\
6.1 \\
5.6\end{array}$ & $\begin{array}{l}26 \\
22 \\
18 \\
15 \\
13\end{array}$ & $\begin{array}{r}103 \\
84 \\
69 \\
60 \\
55\end{array}$ & $\begin{array}{l}301 \\
268 \\
231 \\
198 \\
181\end{array}$ & $\begin{array}{l}28 \\
24 \\
21 \\
19 \\
17\end{array}$ \\
\hline $\begin{array}{l}26 \\
27 \\
28 \\
29 \\
30 \\
31\end{array}$ & $\begin{array}{l}43 \\
42 \\
42 \\
39 \\
36 \\
33\end{array}$ & $\begin{array}{l}28 \\
27 \\
27 \\
27 \\
25 \\
22\end{array}$ & $\begin{array}{l}6.8 \\
6.4 \\
5.9 \\
5.6 \\
5.1 \\
4.6\end{array}$ & $\begin{array}{l}12 \\
11 \\
10 \\
10 \\
9.1 \\
8.4\end{array}$ & $\begin{array}{l}5.2 \\
4.9 \\
4.4 \\
4.3 \\
3.8 \\
3.4\end{array}$ & $\begin{array}{l}12 \\
11 \\
9.7 \\
9.2 \\
8.2 \\
6.8\end{array}$ & $\begin{array}{l}52 \\
48 \\
46 \\
45 \\
40 \\
35\end{array}$ & $\begin{array}{l}164 \\
153 \\
143 \\
118 \\
115 \\
114\end{array}$ & $\begin{array}{l}16 \\
15 \\
14 \\
12 \\
12 \\
11\end{array}$ \\
\hline $\begin{array}{l}\text { Mean } \\
\text { In. }\end{array}$ & $\begin{array}{l}282 \\
4.70\end{array}$ & $\begin{array}{l}83.0 \\
3.77\end{array}$ & $\begin{array}{l}55.9 \\
2.64\end{array}$ & $\begin{array}{l}65.3 \\
3.29\end{array}$ & $\begin{array}{l}41.8 \\
5.81\end{array}$ & $\begin{array}{l}89.1 \\
5.64\end{array}$ & $\begin{array}{r}356 \\
3.91\end{array}$ & 645 & $\begin{array}{l}71.0 \\
6.44\end{array}$ \\
\hline
\end{tabular}


Table 1.--Daily and monthly discharge, in cubic feet per second, and runoff, in inches, at gaging stations--Continued

\begin{tabular}{|c|c|c|c|c|c|c|c|c|c|}
\hline \multirow{2}{*}{$\begin{array}{l}\text { Oct. } \\
1954\end{array}$} & \multicolumn{9}{|c|}{ Station number } \\
\hline & $a(12)$ & (13) & ${ }^{b}\left(\mathrm{IL}_{4}\right)$ & (15) & (16) & (17) & (18) & (19) & (20) \\
\hline $\begin{array}{l}1 \\
2 \\
3 \\
4 \\
5\end{array}$ & $\begin{array}{l}1.65 \\
1.66 \\
2.00 \\
2.17 \\
2.29\end{array}$ & $\begin{array}{l}28 \\
22 \\
32 \\
28 \\
30\end{array}$ & $\begin{array}{l}-- \\
-- \\
-- \\
--\end{array}$ & $\begin{array}{r}44 \\
37 \\
327 \\
1,220 \\
460\end{array}$ & $\begin{array}{l}40 \\
42 \\
335 \\
410 \\
250\end{array}$ & $\begin{array}{r}89 \\
89 \\
101 \\
140 \\
146\end{array}$ & $\begin{array}{l}310 \\
310 \\
385 \\
570 \\
570\end{array}$ & $\begin{array}{r}46 \\
43 \\
334 \\
840 \\
865\end{array}$ & $\begin{array}{l}144 \\
142 \\
234 \\
620 \\
970\end{array}$ \\
\hline $\begin{array}{r}6 \\
7 \\
8 \\
9 \\
10\end{array}$ & $\begin{array}{l}2.30 \\
2.30 \\
2.29 \\
2.34 \\
2.82\end{array}$ & $\begin{array}{r}30 \\
26 \\
22 \\
22 \\
729\end{array}$ & $\overline{--}$ & $\begin{array}{r}385 \\
229 \\
145 \\
118 \\
1,780\end{array}$ & $\begin{array}{r}180 \\
98 \\
73 \\
62 \\
1,190\end{array}$ & $\begin{array}{l}164 \\
149 \\
137 \\
131 \\
567\end{array}$ & $\begin{array}{l}621 \\
587 \\
522 \\
492 \\
971\end{array}$ & $\begin{array}{r}890 \\
640 \\
350 \\
292 \\
1,800\end{array}$ & $\begin{array}{r}1,060 \\
1,030 \\
940 \\
664 \\
785\end{array}$ \\
\hline $\begin{array}{l}11 \\
12 \\
13 \\
14 \\
15\end{array}$ & $\begin{array}{l}2.98 \\
2.98 \\
2.96 \\
2.89 \\
2.87\end{array}$ & $\begin{array}{r}3,340 \\
2,600 \\
1,480 \\
961 \\
738\end{array}$ & $\begin{array}{l}3,230 \\
3,110 \\
2,490 \\
1,870 \\
1,540\end{array}$ & $\begin{array}{r}2,600 \\
1,110 \\
546 \\
374 \\
420\end{array}$ & $\begin{array}{r}2,740 \\
1,280 \\
662 \\
415 \\
385\end{array}$ & $\begin{array}{l}655 \\
599 \\
458 \\
435 \\
485\end{array}$ & $\begin{array}{l}1,360 \\
1,420 \\
1,430 \\
1,440 \\
1,500\end{array}$ & $\begin{array}{l}4,050 \\
5,210 \\
5,310 \\
4,830 \\
4,010\end{array}$ & $\begin{array}{l}1,630 \\
2,920 \\
3,960 \\
5,030 \\
5,600\end{array}$ \\
\hline $\begin{array}{l}16 \\
17 \\
18 \\
19 \\
20\end{array}$ & $\begin{array}{l}2.82 \\
2.76 \\
2.71 \\
2.70 \\
2.65\end{array}$ & $\begin{array}{l}599 \\
458 \\
381 \\
320 \\
253\end{array}$ & $\begin{array}{r}1,300 \\
1,130 \\
985 \\
872 \\
749\end{array}$ & $\begin{array}{l}672 \\
638 \\
330 \\
231 \\
180\end{array}$ & $\begin{array}{l}382 \\
416 \\
273 \\
185 \\
130\end{array}$ & $\begin{array}{l}536 \\
509 \\
442 \\
367 \\
328\end{array}$ & $\begin{array}{l}1,570 \\
1,620 \\
1,620 \\
1,590 \\
1,580\end{array}$ & $\begin{array}{l}3,270 \\
2,710 \\
2,280 \\
1,950 \\
1,670\end{array}$ & $\begin{array}{l}5,550 \\
5,020 \\
4,300 \\
3,550 \\
2,870\end{array}$ \\
\hline $\begin{array}{l}21 \\
22 \\
23 \\
24 \\
25\end{array}$ & $\begin{array}{l}2.60 \\
2.52 \\
2.44 \\
2.36 \\
2.30\end{array}$ & $\begin{array}{l}210 \\
188 \\
162 \\
144 \\
126\end{array}$ & $\begin{array}{r}627 \\
542 \\
465 \\
-- \\
-\end{array}$ & $\begin{array}{r}144 \\
122 \\
100 \\
91 \\
82\end{array}$ & $\begin{array}{r}107 \\
89 \\
82 \\
77 \\
76\end{array}$ & $\begin{array}{l}297 \\
271 \\
249 \\
232 \\
221\end{array}$ & $\begin{array}{l}1,540 \\
1,520 \\
1,490 \\
1,460 \\
1,440\end{array}$ & $\begin{array}{r}1,390 \\
1,120 \\
908 \\
754 \\
654\end{array}$ & $\begin{array}{l}2,360 \\
1,920 \\
1,560 \\
1,300 \\
1,100\end{array}$ \\
\hline $\begin{array}{l}26 \\
27 \\
28 \\
29 \\
30 \\
31\end{array}$ & $\begin{array}{l}2.26 \\
2.20 \\
2.13 \\
2.07 \\
2.04 \\
2.00\end{array}$ & $\begin{array}{r}108 \\
98 \\
88 \\
77 \\
70 \\
64\end{array}$ & $\begin{array}{l}-- \\
-- \\
-- \\
-- \\
-\end{array}$ & $\begin{array}{l}79 \\
79 \\
79 \\
74 \\
74 \\
69\end{array}$ & $\begin{array}{l}72 \\
71 \\
68 \\
66 \\
62 \\
55\end{array}$ & $\begin{array}{l}220 \\
220 \\
220 \\
220 \\
220 \\
220\end{array}$ & $\begin{array}{l}1,410 \\
1,390 \\
1,360 \\
1,340 \\
1,320 \\
1,290\end{array}$ & $\begin{array}{l}588 \\
530 \\
481 \\
446 \\
419 \\
396\end{array}$ & $\begin{array}{l}960 \\
878 \\
816 \\
770 \\
730 \\
687\end{array}$ \\
\hline $\begin{array}{l}\text { Mean } \\
\text { In. }\end{array}$ & - & $\begin{array}{r}433 \\
3.99\end{array}$ & - & $\begin{array}{r}414 \\
7.59\end{array}$ & $\begin{array}{r}335 \\
4.91\end{array}$ & $\begin{array}{r}294 \\
2.22\end{array}$ & $\begin{array}{r}1,160 \\
2.63\end{array}$ & $\begin{array}{r}1,580 \\
6.41\end{array}$ & $\begin{array}{r}1,940 \\
5.26\end{array}$ \\
\hline
\end{tabular}

a Figures given are daily mean stage, in feet-m-discharge not determined at this station.

b See Remarks paragraph of station description. 
Table 1.--Daily and monthly discharge, in cubic feet per second, and runoff, in inches, at gaging stations-Continued

\begin{tabular}{|c|c|c|c|c|c|c|c|c|c|}
\hline \multirow{2}{*}{$\begin{array}{l}\text { Oct. } \\
1954\end{array}$} & \multicolumn{9}{|c|}{ Station number } \\
\hline & (2I) & $(22)$ & $(23)$ & $(24)$ & $(25)$ & $(26)$ & $(27)$ & $(28)$ & (29) \\
\hline 1 & 550 & 642 & 16 & 9.2 & 28 & 795 & 754 & 15 & 0.1 \\
\hline 2 & 575 & 660 & 15 & 8.0 & 25 & 810 & 754 & 27 & \\
\hline 3 & 600 & 678 & 15 & 8.0 & 29 & 840 & 790 & 117 & 1.4 \\
\hline 4 & 1,050 & 852 & 16 & 8.4 & 29 & 896 & 844 & 169 & \\
\hline 5 & 1,480 & 1,270 & 16 & 11 & 31 & 1,060 & 980 & 181 & 1.2 \\
\hline 6 & 1,660 & 1,550 & 17 & 9.6 & 35 & 1,320 & 1,230 & 183 & 2.0 \\
\hline 7 & 1,840 & 1,710 & 16 & 8.0 & 28 & 1,540 & 1,500 & 177 & 1.8 \\
\hline 8 & 1,760 & 1,750 & 15 & 7.7 & 28 & 1,720 & 1,750 & 161 & 1.6 \\
\hline 9 & 1,600 & 1,730 & 15 & 7.4 & 33 & 1,870 & 1,950 & 140 & 1.6 \\
\hline 10 & 1,650 & 1,810 & 368 & 869 & 780 & 2,810 & 2,780 & 179 & 73 \\
\hline 11 & 2,370 & 2,660 & 924 & 1,570 & 1,930 & 4,900 & 8,000 & 350 & 134 \\
\hline 12 & 2,940 & 3,470 & 947 & 914 & 1,940 & 5,260 & 9,700 & 423 & 105 \\
\hline 13 & 3,330 & 3,850 & 888 & 491 & 1,770 & 5,120 & 7,990 & 441 & 72 \\
\hline 14 & 3,670 & 4,020 & 734 & 290 & 1,420 & 5,280 & 7,180 & 433 & 53 \\
\hline 15 & 3,940 & 4,090 & 595 & 171 & 1,090 & 5,400 & 7,400 & 433 & 42 \\
\hline 16 & 4,200 & 4,180 & 452 & 129 & 777 & $5 ; 300$ & 7,270 & 425 & 34 \\
\hline 17 & 4,370 & 4,260 & 358 & 104 & 572 & 5,160 & 6,780 & 401 & 26 \\
\hline 18 & 4,550 & 4,340 & 291 & 87 & 494 & 5,040 & 6,460 & 360 & 20 \\
\hline 19 & 4,840 & 4,360 & 242 & 74 & 425 & 4,960 & 6,190 & 301 & 17 \\
\hline 20 & 5,070 & 4,470 & 201 & 66 & 367 & 4,900 & 6,010 & 238 & 15 \\
\hline 21 & 5,240 & 4,580 & 169 & 58 & 319 & 4,900 & 5,830 & 190 & 13 \\
\hline 22 & 5,290 & 4,690 & 148 & 50 & 283 & 4,900 & 5,650 & 155 & 12 \\
\hline 23 & 5,260 & 4,770 & 134 & 42 & 259 & 4,940 & 5,600 & 134 & 10 \\
\hline 24 & 5,170 & 4,830 & 122 & 40 & 237 & 5,000 & 5,600 & 115 & 9.4 \\
\hline 25 & 5,030 & 4,890 & 112 & 37 & 225 & 5,060 & 5,600 & 107 & 8.9 \\
\hline 26 & 4,880 & 4,990 & 106 & 34 & 216 & 5,100 & 5,650 & 101 & 9.1 \\
\hline 27 & 4,710 & 5,030 & 100 & 32 & 209 & 5,120 & 5,650 & 102 & 9.1 \\
\hline 28 & 4,510 & 4,920 & 94 & 30 & 202 & 5,220 & 5,650 & 107 & 8.6 \\
\hline 29 & 4,340 & 4,830 & 91 & 28 & 198 & 5,220 & 5,700 & 102 & 7.9 \\
\hline 30 & 4,200 & 4,750 & 88 & 27 & 191 & 5,200 & 5,650 & 95 & 7.2 \\
\hline 31 & 4,050 & 4,770 & 86 & 26 & 182 & 5,100 & 5,560 & 84 & 6.6 \\
\hline $\begin{array}{l}\text { Mean } \\
\text { In. }\end{array}$ & $\begin{array}{r}3,380 \\
2.97\end{array}$ & $\begin{array}{r}3,400 \\
2.24\end{array}$ & $\begin{array}{r}238 \\
2.25\end{array}$ & $\begin{array}{r}169 \\
3.57\end{array}$ & $\begin{array}{r}463 \\
2.43\end{array}$ & $\begin{array}{r}3,895 \\
1.92\end{array}$ & $\begin{array}{r}4,790 \\
1.05\end{array}$ & $\begin{array}{r}208 \\
1.12\end{array}$ & $\begin{array}{l}22.7 \\
1.35\end{array}$ \\
\hline
\end{tabular}


Table 1.--Daily and monthly discharge, in cubic feet per second, and runoff, in inches, at gaging stations--Continued

\begin{tabular}{|c|c|c|c|c|c|c|c|c|c|}
\hline \multirow{2}{*}{$\begin{array}{l}\text { Oct. } \\
1954\end{array}$} & \multicolumn{9}{|c|}{ Station number } \\
\hline & $(30)$ & (3I) & (32) & (33) & $(34)$ & $(35)$ & (36) & (37) & $(38)$ \\
\hline $\begin{array}{l}1 \\
2 \\
3 \\
4 \\
5\end{array}$ & $\begin{array}{r}23 \\
30 \\
74 \\
158 \\
200\end{array}$ & $\begin{array}{l}0 \\
0 \\
.6 \\
2.1 \\
2.0\end{array}$ & $\begin{array}{l}5.0 \\
8.8 \\
31 \\
4.3 \\
21 .\end{array}$ & $\begin{array}{l}0.2 \\
1.1 \\
40 \\
16 \\
44\end{array}$ & $\begin{array}{l}1.0 \\
.8 \\
13 \\
3.7 \\
11 .\end{array}$ & $\begin{array}{r}9.0 \\
8.2 \\
101 \\
82 \\
119\end{array}$ & $\begin{array}{l}0.9 \\
.8 \\
14 \\
14 \\
23\end{array}$ & $\begin{array}{r}38 \\
36 \\
430 \\
320 \\
529\end{array}$ & $\begin{array}{r}3.4 \\
3.2 \\
173 \\
73 \\
97\end{array}$ \\
\hline $\begin{array}{r}6 \\
7 \\
8 \\
9 \\
10\end{array}$ & $\begin{array}{l}206 \\
200 \\
195 \\
191 \\
785\end{array}$ & $\begin{array}{r}3.3 \\
2.5 \\
2.1 \\
3.4 \\
67\end{array}$ & $\begin{array}{r}5.6 \\
4.2 \\
4.2 \\
48 \\
329\end{array}$ & $\begin{array}{r}34 \\
20 \\
15 \\
32 \\
228\end{array}$ & $\begin{array}{c}7.9 \\
5.0 \\
4.0 \\
10 \\
268\end{array}$ & $\begin{array}{r}117 \\
90 \\
67 \\
60 \\
812\end{array}$ & $\begin{array}{r}24 \\
17 \\
11 \\
15 \\
289\end{array}$ & $\begin{array}{r}500 \\
392 \\
329 \\
350 \\
2,720\end{array}$ & $\begin{array}{r}55 \\
30 \\
21 \\
50 \\
945\end{array}$ \\
\hline $\begin{array}{l}11 \\
12 \\
13 \\
14 \\
15\end{array}$ & $\begin{array}{r}1,750 \\
1,260 \\
869 \\
794 \\
749\end{array}$ & $\begin{array}{r}131 \\
68 \\
36 \\
30 \\
30\end{array}$ & $\begin{array}{r}210 \\
90 \\
55 \\
54 \\
38\end{array}$ & $\begin{array}{l}337 \\
218 \\
149 \\
120 \\
109\end{array}$ & $\begin{array}{l}422 \\
263 \\
193 \\
160 \\
131\end{array}$ & $\begin{array}{r}1,670 \\
1,500 \\
1,270 \\
884 \\
669\end{array}$ & $\begin{array}{r}496 \\
187 \\
80 \\
41 \\
35\end{array}$ & $\begin{array}{l}5,870 \\
5,360 \\
3,990 \\
2,790 \\
2,170\end{array}$ & $\begin{array}{r}567 \\
291 \\
165 \\
106 \\
76\end{array}$ \\
\hline $\begin{array}{l}16 \\
17 . \\
18 \\
19 \\
20\end{array}$ & $\begin{array}{l}688 \\
633 \\
587 \\
526 \\
444\end{array}$ & $\begin{array}{l}22 \\
17 \\
14 \\
12 \\
11\end{array}$ & $\begin{array}{l}28 \\
22 \\
20 \\
16 \\
14\end{array}$ & $\begin{array}{l}84 \\
66 \\
57 \\
49 \\
41\end{array}$ & $\begin{array}{l}99 \\
76 \\
59 \\
50 \\
44\end{array}$ & $\begin{array}{l}520 \\
390 \\
272 \\
220 \\
182\end{array}$ & $\begin{array}{l}26 \\
20 \\
17 \\
17 \\
15\end{array}$ & $\begin{array}{r}1,760 \\
1,460 \\
1,230 \\
1,080 \\
938\end{array}$ & $\begin{array}{l}61 \\
52 \\
47 \\
40 \\
35\end{array}$ \\
\hline $\begin{array}{l}21 \\
22 \\
23 \\
24 \\
25\end{array}$ & $\begin{array}{l}358 \\
295 \\
246 \\
217 \\
190\end{array}$ & $\begin{array}{l}9.1 \\
8.0 \\
7.3 \\
6.6 \\
5.9\end{array}$ & $\begin{array}{l}12 \\
11 \\
9.6 \\
8.8 \\
8.8\end{array}$ & $\begin{array}{l}36 \\
31 \\
27 \\
23 \\
21\end{array}$ & $\begin{array}{l}38 \\
34 \\
31 \\
28 \\
25\end{array}$ & $\begin{array}{l}162 \\
147 \\
132 \\
123 \\
113\end{array}$ & $\begin{array}{l}13 \\
12 \\
11 \\
9.7 \\
8.4\end{array}$ & $\begin{array}{l}792 \\
663 \\
561 \\
484 \\
420\end{array}$ & $\begin{array}{l}30 \\
27 \\
25 \\
22 \\
22\end{array}$ \\
\hline $\begin{array}{l}26 \\
27 \\
28 \\
29 \\
30 \\
31\end{array}$ & $\begin{array}{l}180 \\
175 \\
170 \\
160 \\
150 \\
140\end{array}$ & $\begin{array}{l}5.8 \\
5.9 \\
5.6 \\
5.2 \\
5.0 \\
4.6\end{array}$ & $\begin{array}{l}8.6 \\
8.7 \\
7.8 \\
7.6 \\
6.7 \\
6.3\end{array}$ & $\begin{array}{l}20 \\
19 \\
16 \\
15 \\
12 \\
10\end{array}$ & $\begin{array}{l}24 \\
23 \\
21 \\
19 \\
16 \\
15\end{array}$ & $\begin{array}{r}110 \\
106 \\
95 \\
82 \\
73 \\
67\end{array}$ & $\begin{array}{l}8.4 \\
8.0 \\
7.6 \\
6.8 \\
6.4 \\
6.4\end{array}$ & $\begin{array}{l}392 \\
378 \\
350 \\
332 \\
314 \\
290\end{array}$ & $\begin{array}{l}20 \\
18 \\
17 \\
15 \\
13 \\
13\end{array}$ \\
\hline $\begin{array}{l}\text { Mean } \\
\text { In. }\end{array}$ & $\begin{array}{r}408 \\
1.26\end{array}$ & $\begin{array}{l}16.9 \\
2.59\end{array}$ & $\begin{array}{l}35.6 \\
3.13\end{array}$ & $\begin{array}{l}61.0 \\
3.59\end{array}$ & $\begin{array}{l}67.6 \\
2.31\end{array}$ & $\begin{array}{r}331 \\
3.13\end{array}$ & $\begin{array}{l}46.5 \\
2.94\end{array}$ & $\begin{array}{r}1,202 \\
2.18\end{array}$ & $\begin{array}{l}100 \\
7.15\end{array}$ \\
\hline
\end{tabular}


Table 1.--Daily and monthly discharge, in cubic feet per second, and runoff, in inches, at gaging stations--Continued

\begin{tabular}{|c|c|c|c|c|c|c|c|c|c|}
\hline \multirow{2}{*}{$\begin{array}{l}\text { Oct. } \\
1954\end{array}$} & \multicolumn{9}{|c|}{ Station number } \\
\hline & (39) & $(40)$ & $(41)$ & $(42)$ & $\left(44_{4}\right)$ & $c(45)$ & $d(45)$ & $e(45)$ & $(46)$ \\
\hline $\begin{array}{l}1 \\
2 \\
3 \\
4 \\
5\end{array}$ & $\begin{array}{r}0.6 \\
.6 \\
4.8 \\
6.2 \\
3.9\end{array}$ & $\begin{array}{c}4.0 \\
8.0 \\
29 \\
7.7 \\
8.8\end{array}$ & $\begin{array}{l}0.3 \\
.3 \\
14 \\
3.0 \\
11\end{array}$ & $\begin{array}{c}9.7 \\
11 \\
109 \\
54 \\
88\end{array}$ & $\begin{array}{r}0 \\
0 \\
72 \\
28 \\
42\end{array}$ & $\begin{array}{l}3,471 \\
3,393 \\
8,668 \\
4,778 \\
5,813\end{array}$ & $\begin{array}{l}1,800 \\
1,684 \\
1,590 \\
1,816 \\
1,750\end{array}$ & $\begin{array}{l}1,533 \\
1,555 \\
6,760 \\
2,650 \\
3,700\end{array}$ & $\begin{array}{l}0.3 \\
196 \\
127 \\
114\end{array}$ \\
\hline $\begin{array}{r}6 \\
7 \\
8 \\
9 \\
10\end{array}$ & $\begin{array}{r}3.9 \\
2.9 \\
2.0 \\
1.7 \\
80\end{array}$ & $\begin{array}{r}7.2 \\
4.7 \\
3.7 \\
3.9 \\
114\end{array}$ & $\begin{array}{r}6.1 \\
2.0 \\
1.8 \\
1.6 \\
132\end{array}$ & $\begin{array}{r}39 \\
26 \\
19 \\
63 \\
961\end{array}$ & $\begin{array}{c}24 \\
13 \\
8.4 \\
33 \\
891\end{array}$ & $\begin{array}{r}3,654 \\
3,419 \\
3,520 \\
5,022 \\
21,429\end{array}$ & $\begin{array}{l}1,750 \\
1,725 \\
1,720 \\
1,646 \\
1,505\end{array}$ & $\begin{array}{r}1,603 \\
1,440 \\
1,574 \\
3,132 \\
16,940\end{array}$ & $\begin{array}{r}69 \\
35 \\
26 \\
60 \\
2,010\end{array}$ \\
\hline $\begin{array}{l}11 \\
12 \\
13 \\
14 \\
15\end{array}$ & $\begin{array}{r}208 \\
147 \\
60 \\
41 \\
38\end{array}$ & $\begin{array}{r}131 \\
52 \\
29 \\
28 \\
25\end{array}$ & $\begin{array}{r}211 \\
72 \\
30 \\
26 \\
25\end{array}$ & $\begin{array}{r}1,500 \\
1,030 \\
642 \\
436 \\
378\end{array}$ & $\begin{array}{r}546 \\
270 \\
112 \\
79 \\
68\end{array}$ & $\begin{array}{r}20,417 \\
13,760 \\
8,090 \\
5,935 \\
4,517\end{array}$ & $\begin{array}{l}1,736 \\
1,766 \\
1,758 \\
1,744 \\
1,725\end{array}$ & $\begin{array}{r}11,758 \\
5,974 \\
3,055 \\
2,289 \\
1,685\end{array}$ & $\begin{array}{l}789 \\
410 \\
272 \\
190 \\
151\end{array}$ \\
\hline $\begin{array}{l}16 \\
17 \\
18 \\
19 \\
20\end{array}$ & $\begin{array}{l}28 \\
21 \\
18 \\
16 \\
13\end{array}$ & $\begin{array}{l}20 \\
16 \\
15 \\
14 \\
12\end{array}$ & $\begin{array}{l}16 \\
11 \\
11 \\
11 \\
7.7\end{array}$ & $\begin{array}{l}275 \\
195 \\
149 \\
152 \\
106\end{array}$ & $\begin{array}{l}57 \\
51 \\
46 \\
43 \\
41\end{array}$ & $\begin{array}{l}3,960 \\
3,387 \\
3,186 \\
3,361 \\
2,962\end{array}$ & $\begin{array}{l}1,604 \\
1,474 \\
1,685 \\
1,710 \\
1,718\end{array}$ & $\begin{array}{r}1,685 \\
1,417 \\
1,048 \\
1,245 \\
875\end{array}$ & $\begin{array}{r}108 \\
78 \\
62 \\
51 \\
45\end{array}$ \\
\hline $\begin{array}{l}21 \\
22 \\
23 \\
24 \\
25\end{array}$ & $\begin{array}{l}11 \\
9.2 \\
7.8 \\
6.4 \\
5.5\end{array}$ & $\begin{array}{l}9.2 \\
7.7 \\
6.5 \\
6.0 \\
6.3\end{array}$ & $\begin{array}{l}6.2 \\
4.8 \\
3.9 \\
3.2 \\
2.8\end{array}$ & $\begin{array}{l}82 \\
64 \\
49 \\
38 \\
34\end{array}$ & $\begin{array}{l}39 \\
36 \\
34 \\
32 \\
29\end{array}$ & $\begin{array}{l}2,609 \\
2,705 \\
2,636 \\
2,478 \\
2,506\end{array}$ & $\begin{array}{l}1,714 \\
1,715 \\
1,617 \\
1,499 \\
1,710\end{array}$ & $\begin{array}{l}556 \\
684 \\
736 \\
709 \\
533\end{array}$ & $\begin{array}{l}40 \\
36 \\
31 \\
27 \\
23\end{array}$ \\
\hline $\begin{array}{l}26 \\
27 \\
28 \\
29 \\
30 \\
31\end{array}$ & $\begin{array}{l}5.2 \\
5.4 \\
4.7 \\
4.4 \\
3.8 \\
3.3\end{array}$ & $\begin{array}{l}7.2 \\
8.0 \\
7.0 \\
6.5 \\
6.0 \\
4.3\end{array}$ & $\begin{array}{l}3.7 \\
3.0 \\
2.6 \\
2.4 \\
2.5 \\
1.7\end{array}$ & $\begin{array}{l}31 \\
32 \\
33 \\
29 \\
26 \\
22\end{array}$ & $\begin{array}{c}26 \\
24 \\
19 \\
12 \\
11 \\
9.4\end{array}$ & $\begin{array}{l}2,816 \\
2,565 \\
2,492 \\
2,605 \\
2,405 \\
2,631\end{array}$ & $\begin{array}{l}1,709 \\
1,706 \\
1,700 \\
1,682 \\
1,565 \\
1,460\end{array}$ & $\begin{array}{l}857 \\
615 \\
542 \\
681 \\
615 \\
955\end{array}$ & $\begin{array}{l}20 \\
20 \\
18 \\
17 \\
16 \\
15\end{array}$ \\
\hline $\begin{array}{l}\text { Mean } \\
\text { In. }\end{array}$ & $\begin{array}{l}24.6 \\
1.37\end{array}$ & $\begin{array}{l}19.6 \\
1.77\end{array}$ & $\begin{array}{l}20.3 \\
2.04\end{array}$ & $\begin{array}{r}216 \\
2.44\end{array}$ & $\begin{array}{l}87.0 \\
8.87\end{array}$ & $\begin{array}{r}5,200 \\
-\end{array}$ & $\begin{array}{r}1,677 \\
\ldots\end{array}$ & 2,561 & $\begin{array}{c}163 \\
9.04\end{array}$ \\
\hline
\end{tabular}


Table 1.--Daily and monthly discharge, in cubic feet per second, and runoff, in inches, at gaging stations--Continued

\begin{tabular}{|c|c|c|c|c|c|c|c|}
\hline \multirow{2}{*}{$\begin{array}{l}\text { Oct. } \\
1954\end{array}$} & \multicolumn{7}{|c|}{ Station number } \\
\hline & $(48)$ & $(49)$ & $(50)$ & (51) & $(52)$ & $(53)$ & $(54)$ \\
\hline $\begin{array}{l}1 \\
2 \\
3 \\
4 \\
5\end{array}$ & $\begin{array}{r}9.7 \\
9.7 \\
8.9 \\
9.7 \\
25\end{array}$ & $\begin{array}{r}55 \\
55 \\
194 \\
586 \\
503\end{array}$ & $\begin{array}{r}0.4 \\
.7 \\
1.6 \\
1.6 \\
3.4\end{array}$ & $\begin{array}{r}5,100 \\
4,840 \\
8,690 \\
8,800 \\
10,100\end{array}$ & $\begin{array}{r}394 \\
437 \\
549 \\
840 \\
1,180\end{array}$ & $\begin{array}{l}8.7 \\
8.7 \\
15 \\
8.7 \\
14\end{array}$ & $\begin{array}{r}585 \\
575 \\
637 \\
1,590 \\
1,600\end{array}$ \\
\hline $\begin{array}{r}6 \\
7 \\
8 \\
9 \\
10\end{array}$ & $\begin{array}{r}23 \\
26 \\
22 \\
23 \\
3,220\end{array}$ & $\begin{array}{r}622 \\
499 \\
335 \\
269 \\
6,590\end{array}$ & $\begin{array}{l}6.0 \\
6.9 \\
6.9 \\
5.6 \\
21\end{array}$ & $\begin{array}{r}6,780 \\
6,600 \\
6,970 \\
6,780 \\
22,900\end{array}$ & $\begin{array}{l}1,350 \\
1,390 \\
1,400 \\
1,370 \\
1,540\end{array}$ & $\begin{array}{c}14 \\
10 \\
8.5 \\
8.7 \\
165\end{array}$ & $\begin{array}{l}2,140 \\
2,080 \\
2,000 \\
1,980 \\
8,650\end{array}$ \\
\hline $\begin{array}{l}11 \\
12 \\
13 \\
14 \\
15\end{array}$ & $\begin{array}{r}5,060 \\
1,900 \\
1,020 \\
636 \\
418\end{array}$ & $\begin{array}{r}11,400 \\
7,150 \\
3,370 \\
2,240 \\
1,740\end{array}$ & $\begin{array}{l}503 \\
520 \\
359 \\
250 \\
201\end{array}$ & $\begin{array}{l}46,600 \\
54,500 \\
42,000 \\
27,100 \\
20,400\end{array}$ & $\begin{array}{l}1,710 \\
1,830 \\
1,960 \\
1,980 \\
2,110\end{array}$ & $\begin{array}{l}243 \\
174 \\
142 \\
121 \\
105\end{array}$ & $\begin{array}{r}37,900 \\
23,400 \\
10,300 \\
7,580 \\
6,520\end{array}$ \\
\hline $\begin{array}{l}16 \\
17 \\
18 \\
19 \\
20\end{array}$ & $\begin{array}{l}283 \\
218 \\
172 \\
145 \\
125\end{array}$ & $\begin{array}{r}1,340 \\
1,100 \\
935 \\
821 \\
742\end{array}$ & $\begin{array}{r}164 \\
125 \\
95 \\
76 \\
63\end{array}$ & $\begin{array}{l}18,200 \\
15,900 \\
14,100 \\
14,000 \\
12,700\end{array}$ & $\begin{array}{l}2,110 \\
2,020 \\
1,940 \\
1,810 \\
1,630\end{array}$ & $\begin{array}{l}90 \\
78 \\
68 \\
59 \\
51\end{array}$ & $\begin{array}{l}5,870 \\
5,460 \\
5,060 \\
4,730 \\
4,410\end{array}$ \\
\hline $\begin{array}{l}21 \\
22 \\
23 \\
24 \\
25\end{array}$ & $\begin{array}{r}111 \\
101 \\
92 \\
83 \\
77\end{array}$ & $\begin{array}{l}675 \\
615 \\
561 \\
520 \\
481\end{array}$ & $\begin{array}{l}57 \\
49 \\
43 \\
40 \\
36\end{array}$ & $\begin{array}{r}11,500 \\
11,500 \\
10,400 \\
10,500 \\
9,900\end{array}$ & $\begin{array}{r}1,300 \\
1,140 \\
1,040 \\
855 \\
780\end{array}$ & $\begin{array}{l}43 \\
36 \\
30 \\
26 \\
25\end{array}$ & $\begin{array}{l}4,070 \\
3,560 \\
3,180 \\
2,930 \\
2,640\end{array}$ \\
\hline $\begin{array}{l}26 \\
27 \\
28 \\
29 \\
30 \\
31\end{array}$ & $\begin{array}{l}74 \\
68 \\
65 \\
58 \\
55 \\
50\end{array}$ & $\begin{array}{l}455 \\
425 \\
395 \\
377 \\
347 \\
302\end{array}$ & $\begin{array}{l}36 \\
36 \\
33 \\
31 \\
30 \\
28\end{array}$ & $\begin{array}{r}10,500 \\
9,900 \\
9,510 \\
9,330 \\
9,600 \\
9,230\end{array}$ & $\begin{array}{l}753 \\
766 \\
699 \\
699 \\
740 \\
712\end{array}$ & $\begin{array}{l}24 \\
22 \\
20 \\
19 \\
17 \\
15\end{array}$ & $\begin{array}{l}2,440 \\
2,320 \\
2,210 \\
2,100 \\
2,000 \\
1,900\end{array}$ \\
\hline $\begin{array}{l}\text { Mean } \\
\text { In. }\end{array}$ & $\begin{array}{r}458 \\
4.93\end{array}$ & $\begin{array}{r}1,474 \\
5.23\end{array}$ & $\begin{array}{r}91.3 \\
.22\end{array}$ & 15,000 & $\begin{array}{r}1,260 \\
1.06\end{array}$ & $\begin{array}{l}53.8 \\
1.73\end{array}$ & $\begin{array}{l}5,239 \\
2.35\end{array}$ \\
\hline
\end{tabular}




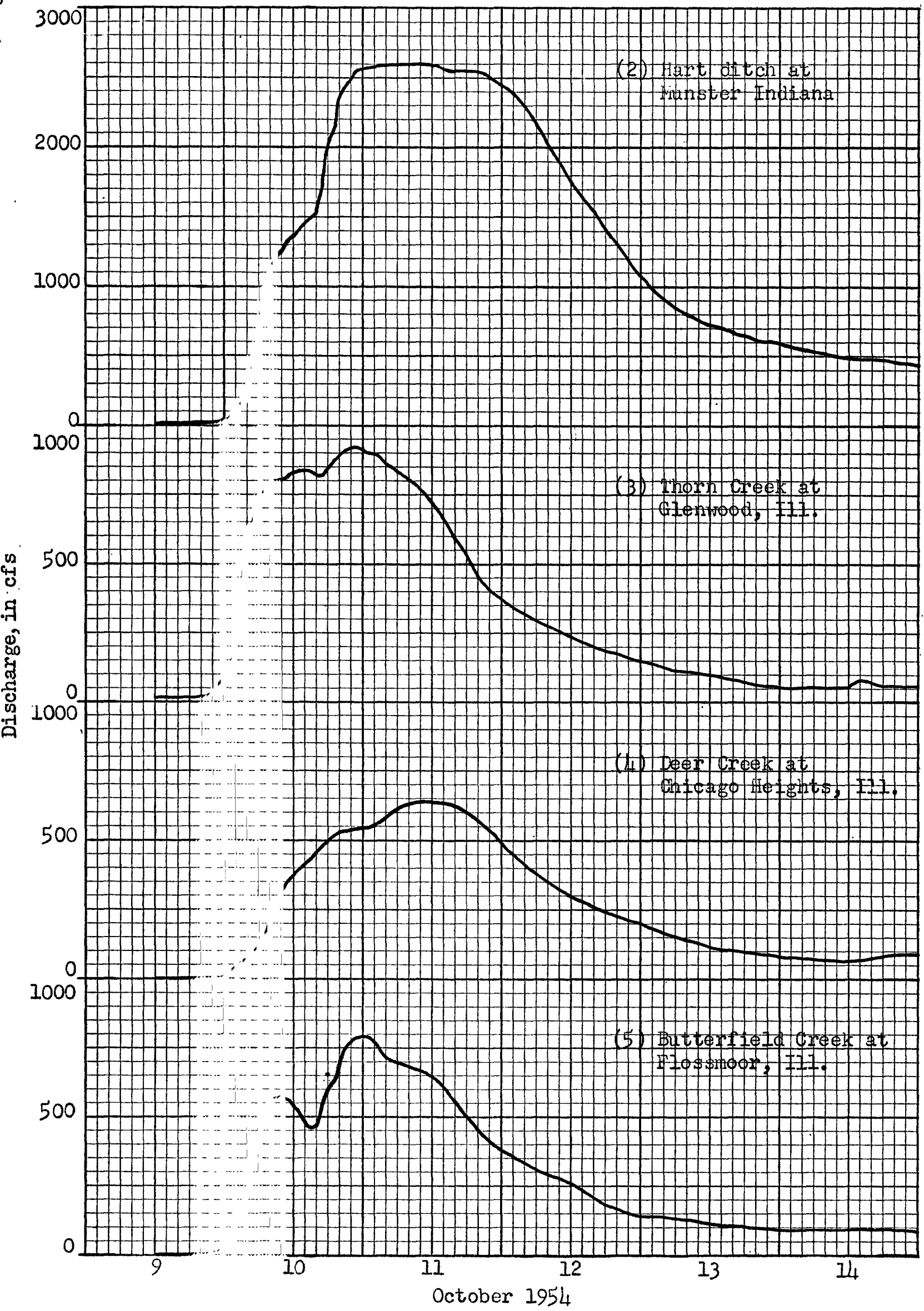

Figure 3.--Hydrographs for stations 2-5 


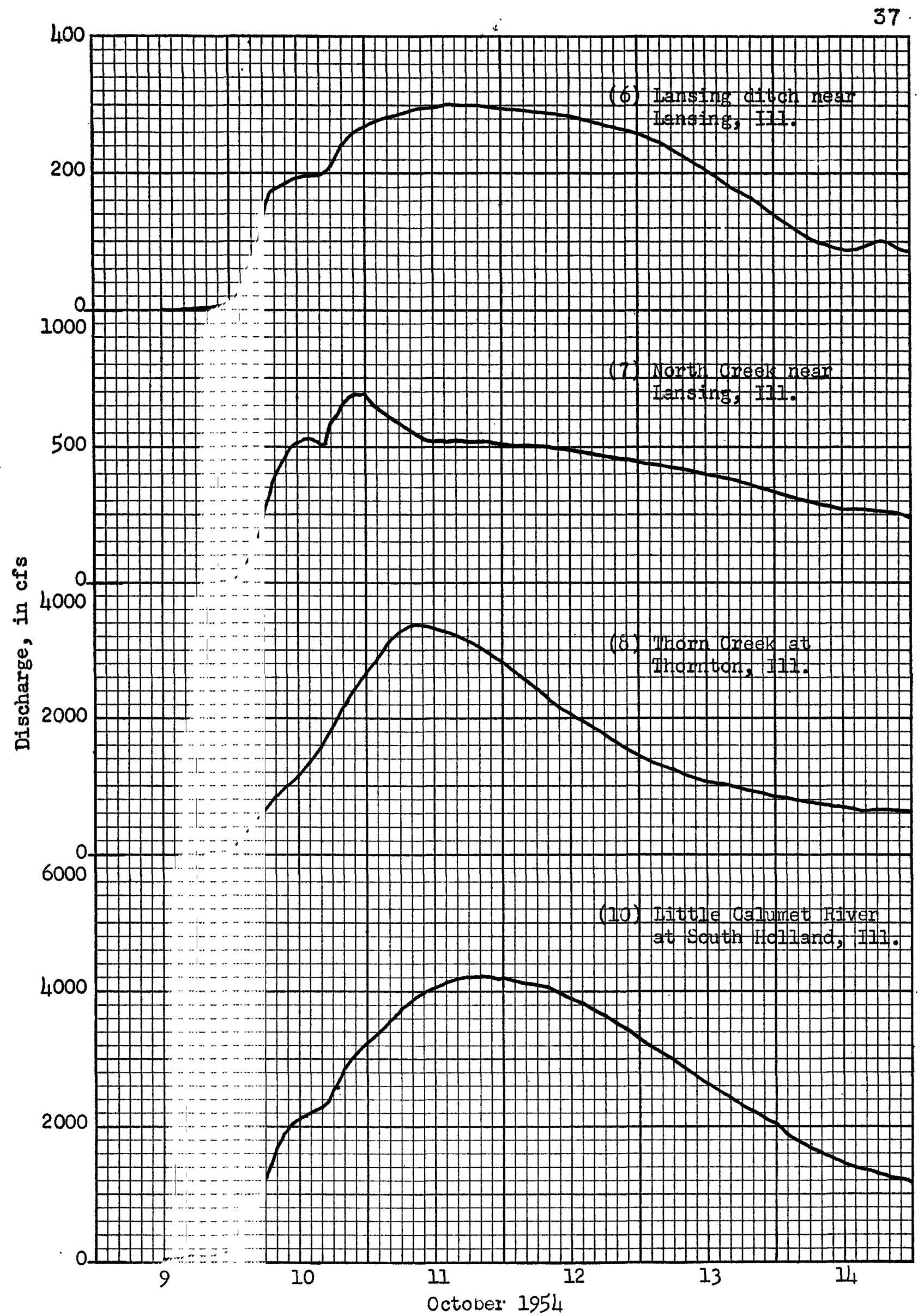

Figure 4.--Hydrographs for stations $6-8,10$ 
38

800

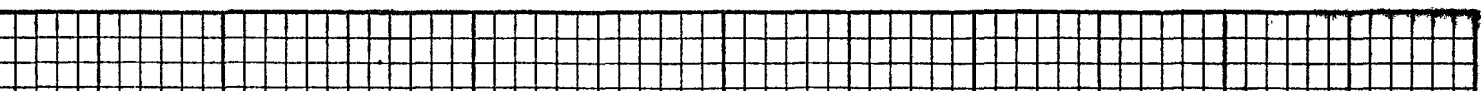

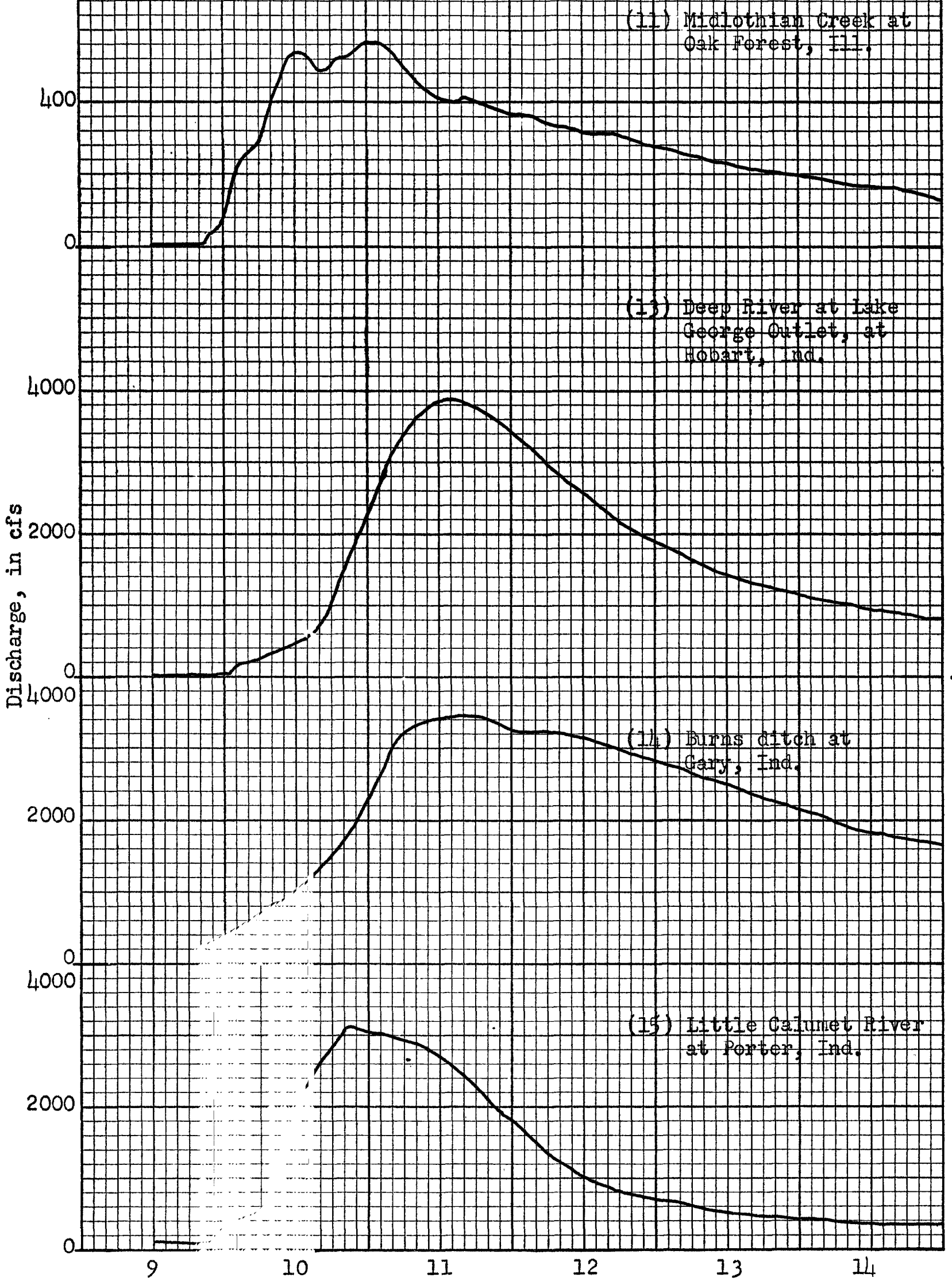

October 1954

Figure 5.--Hydrographs for stations 11, 13-15 


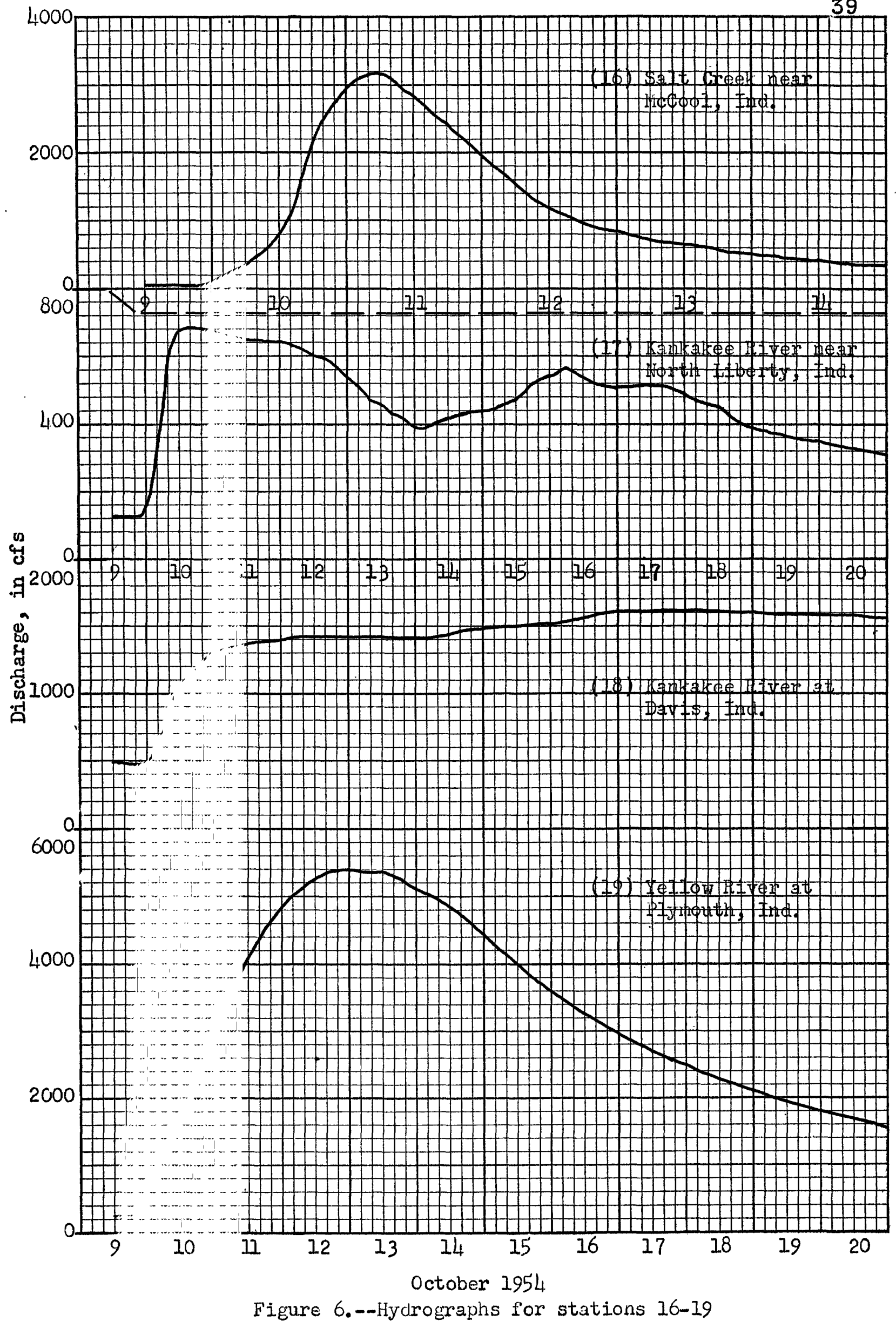




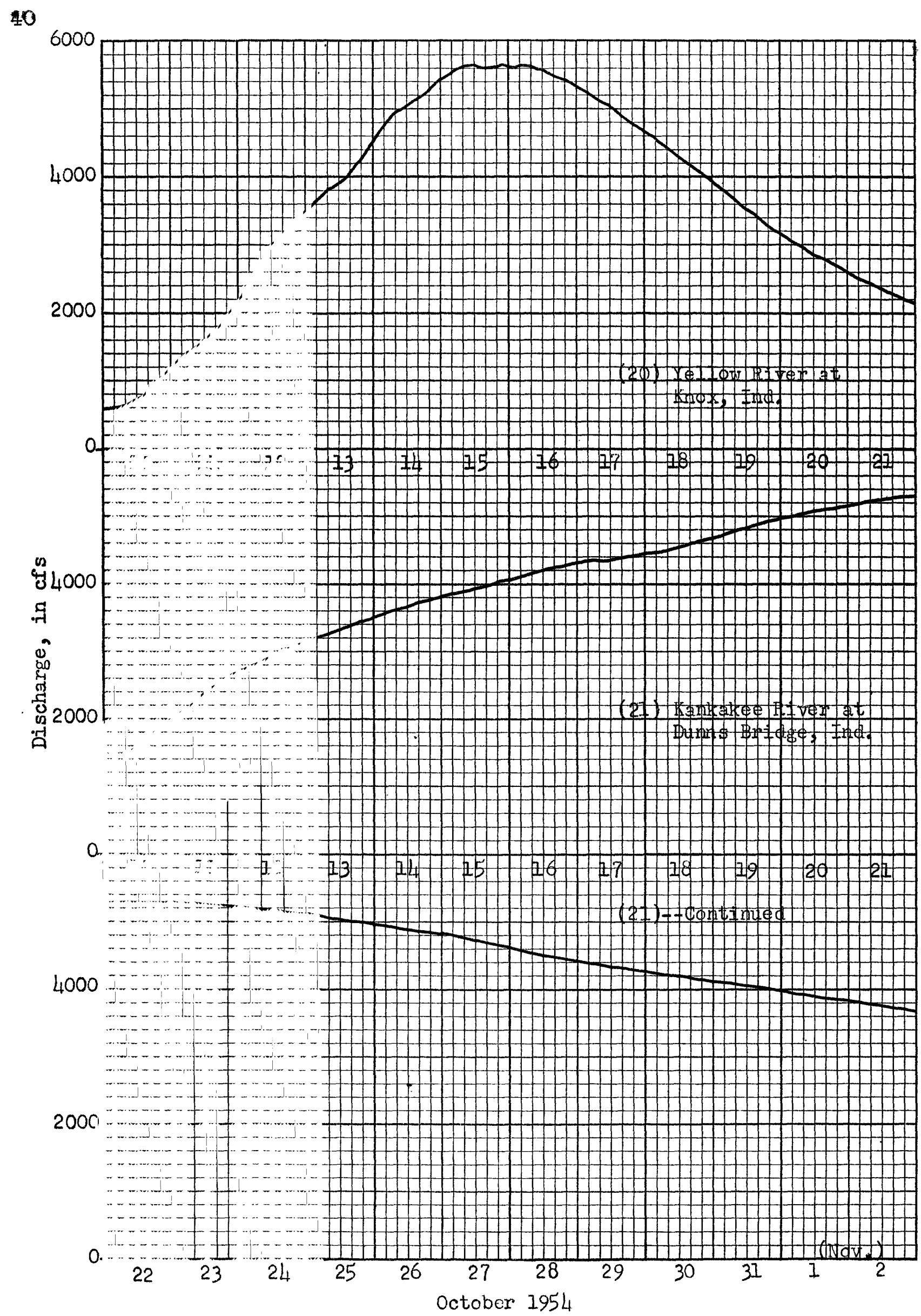

Figure 7.-- Hydrographs for stations 20, 21 


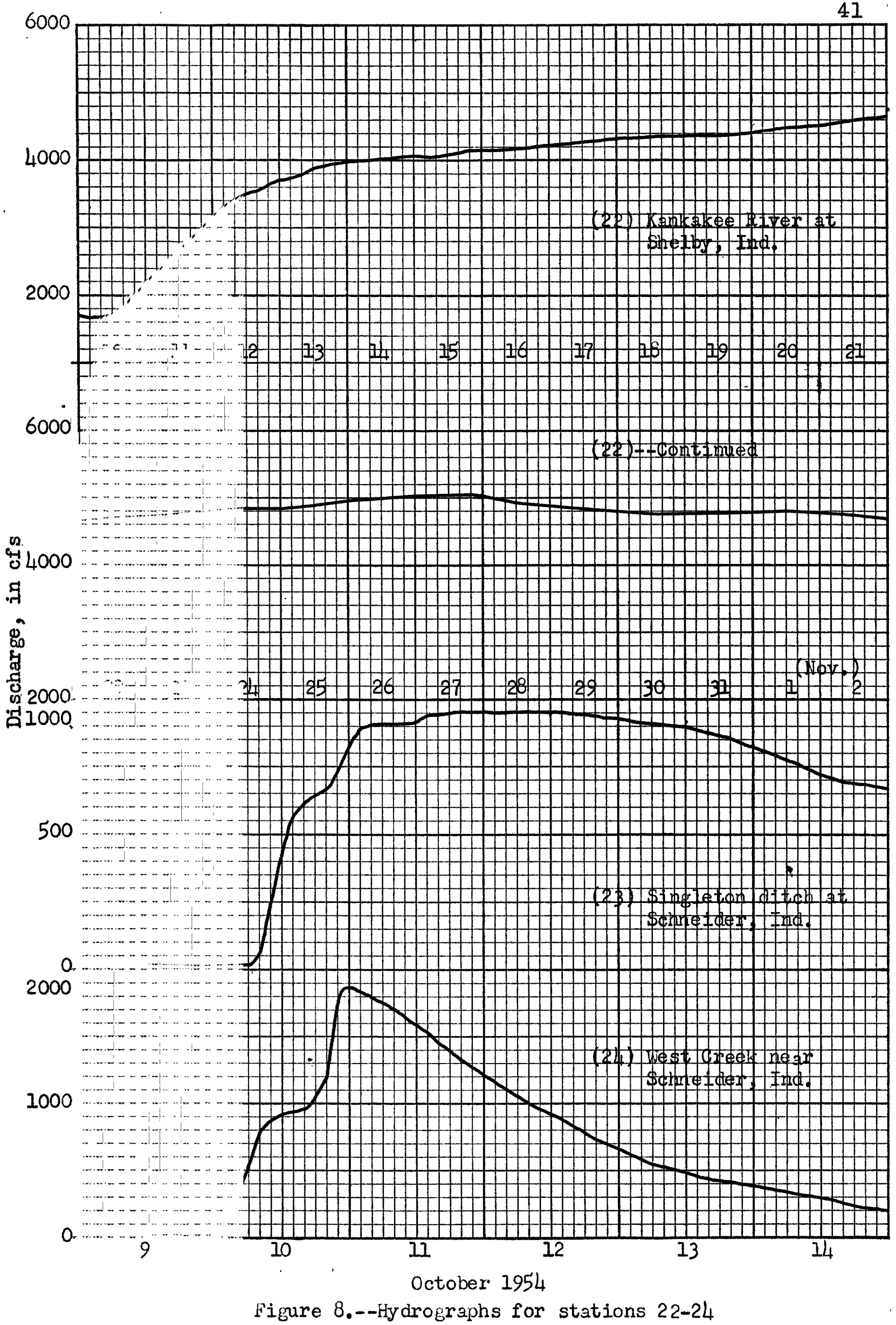


2000
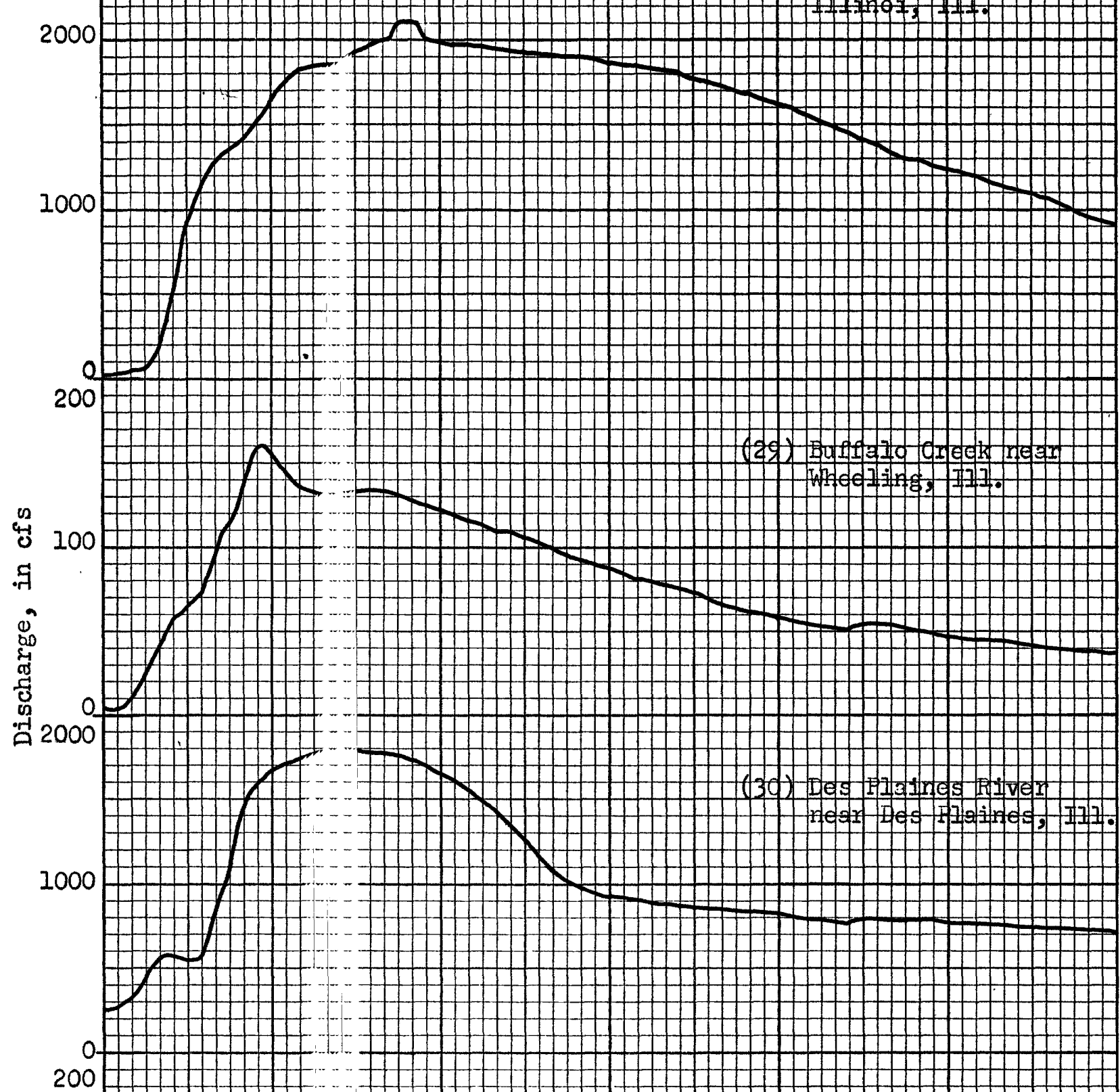


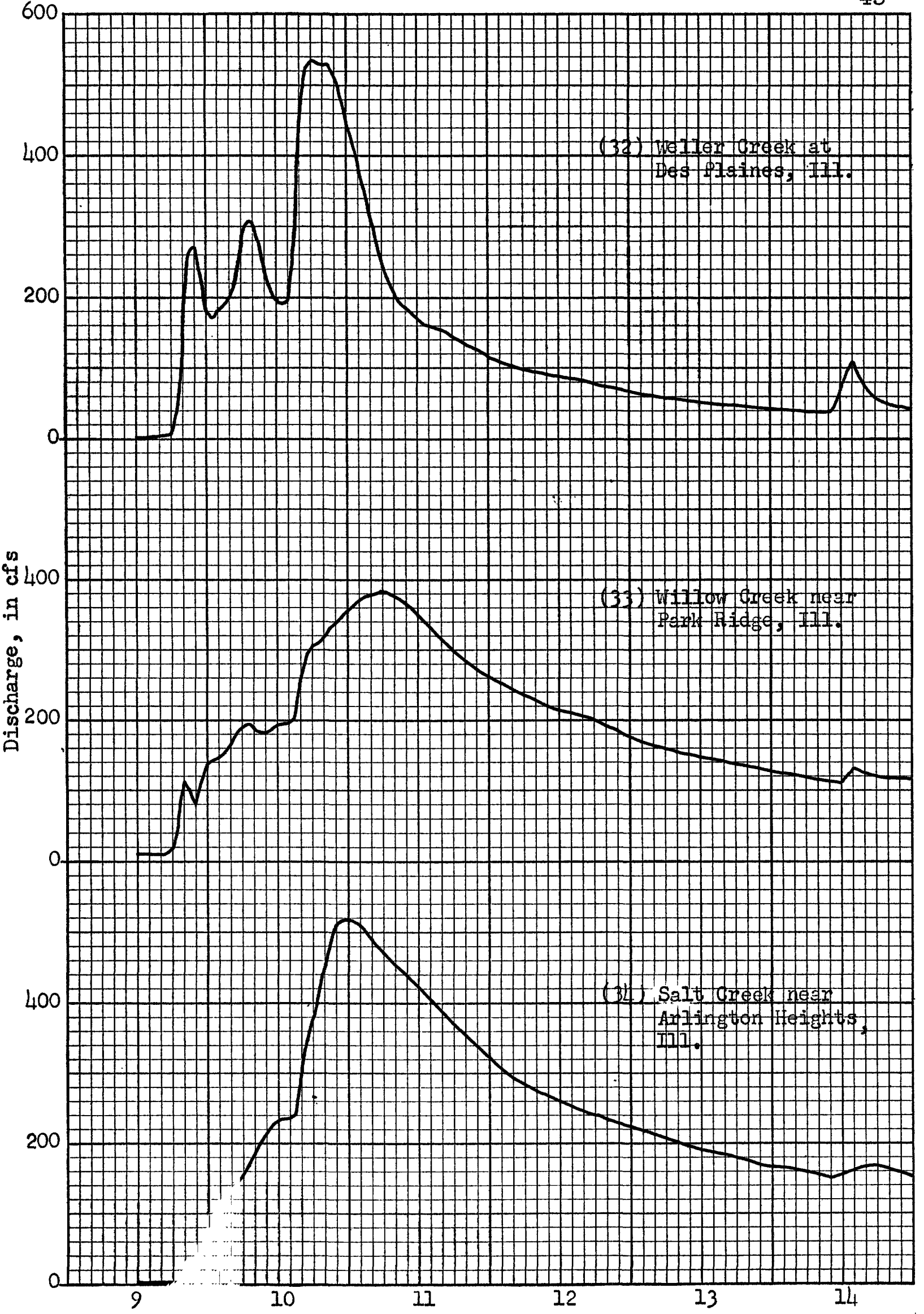

October 1954

Figure 10.--Hydrographs for stations 32-34 


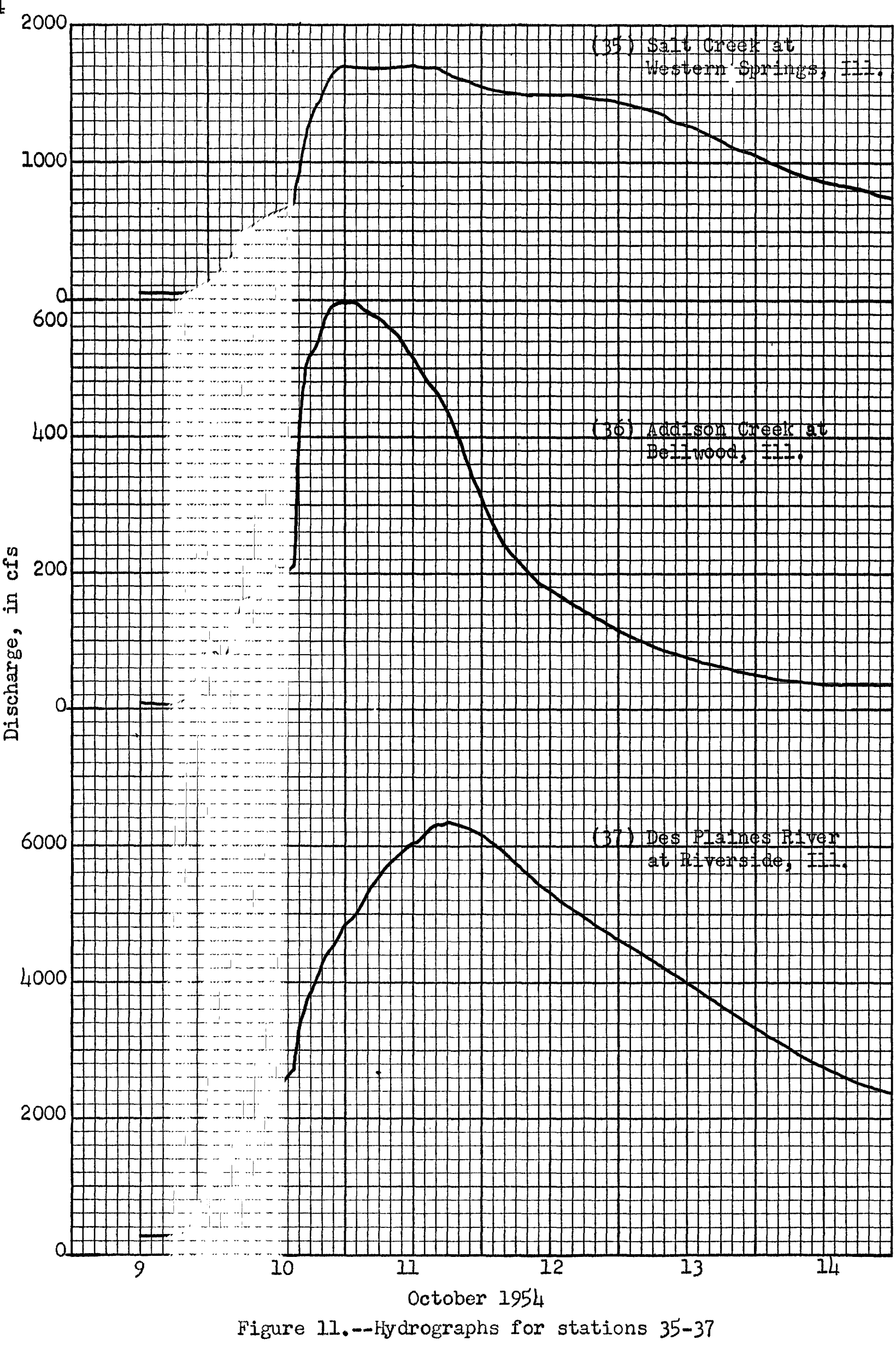




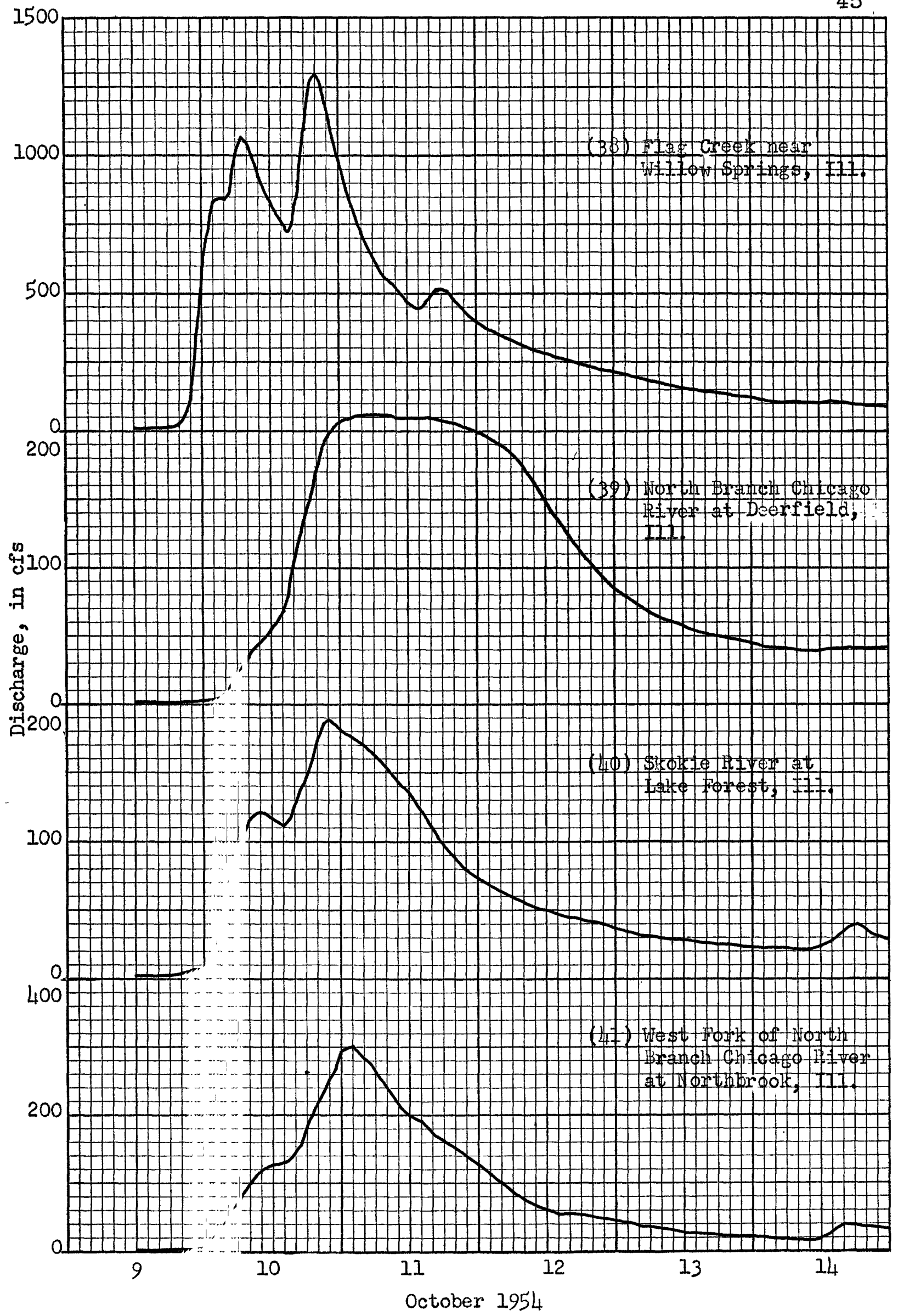

Figure 12.--Hydrographs for stations 38-41 


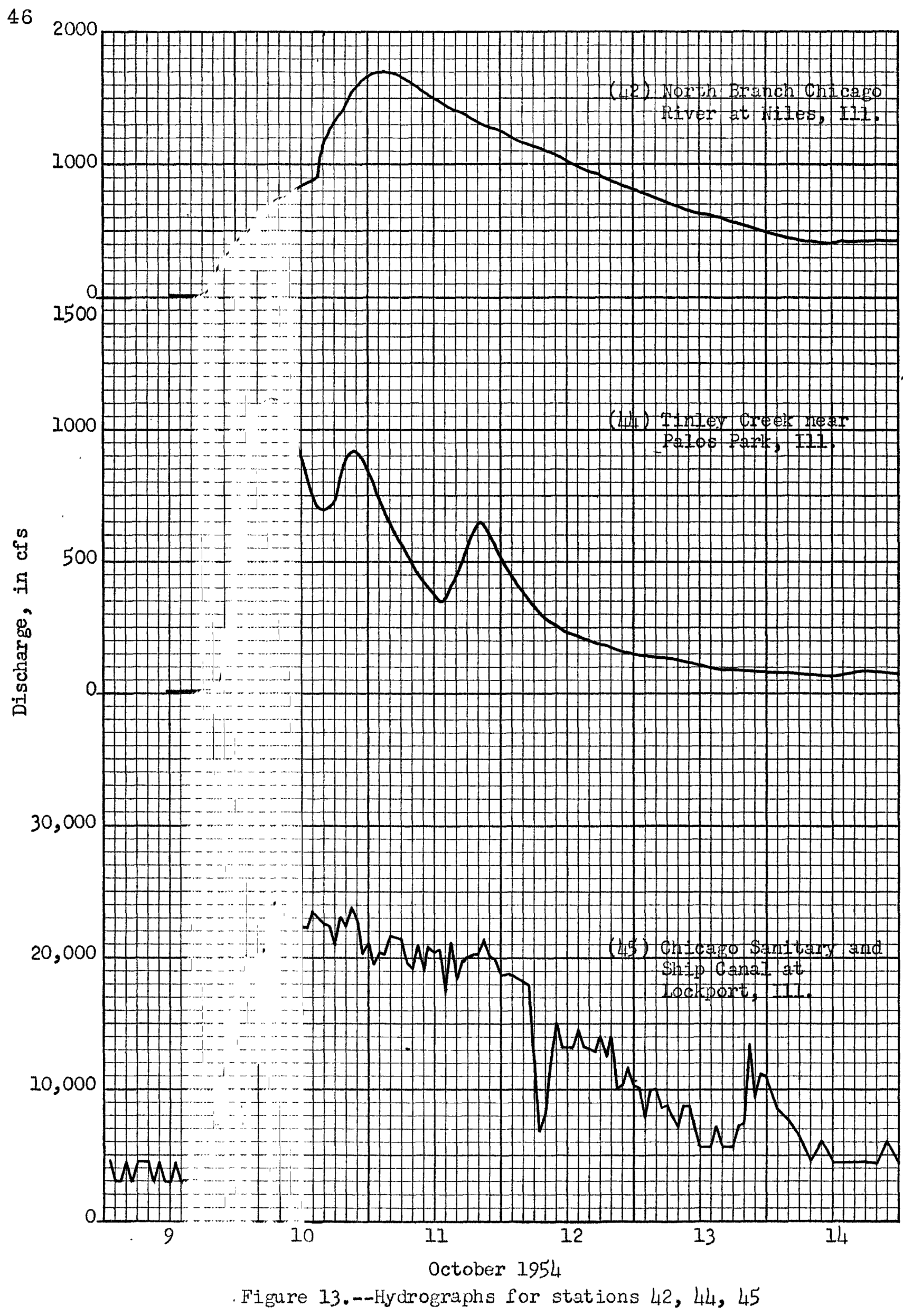




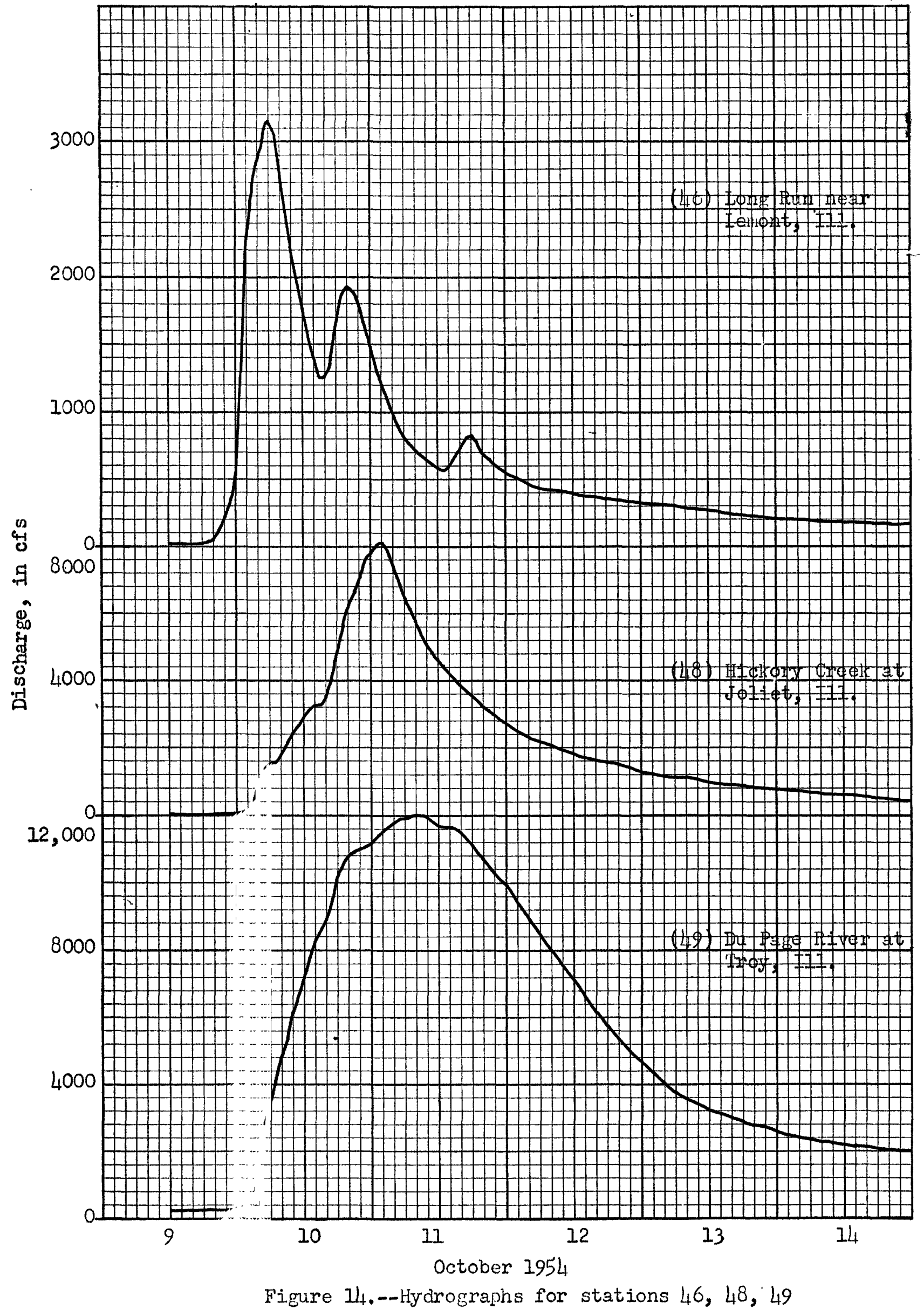




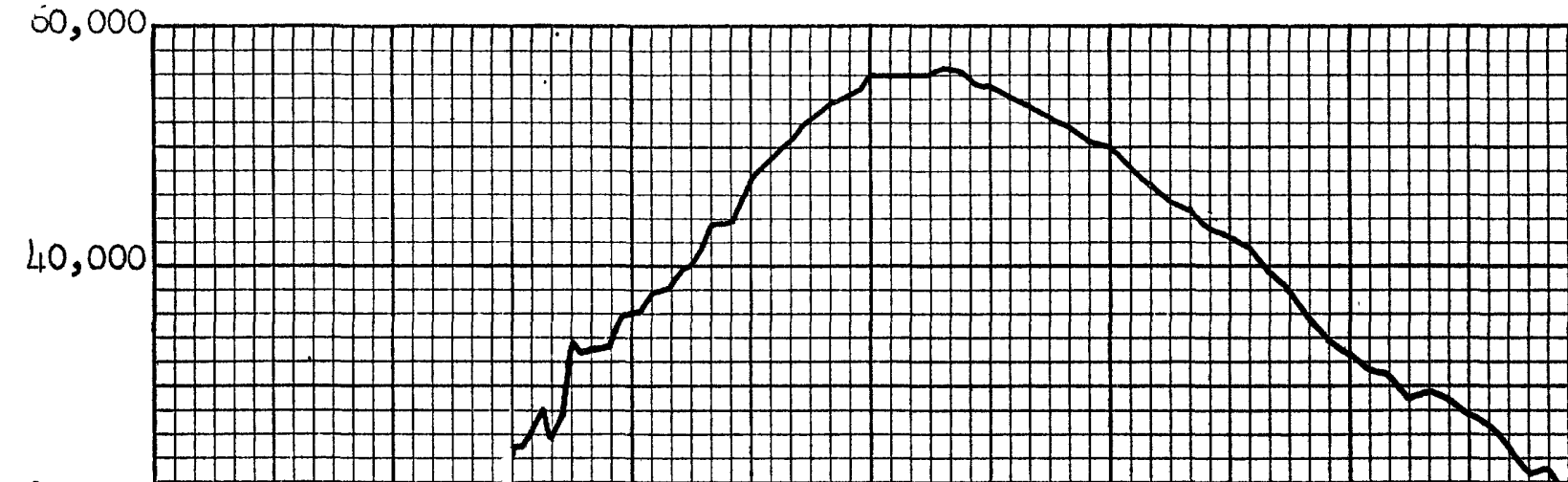

20,000
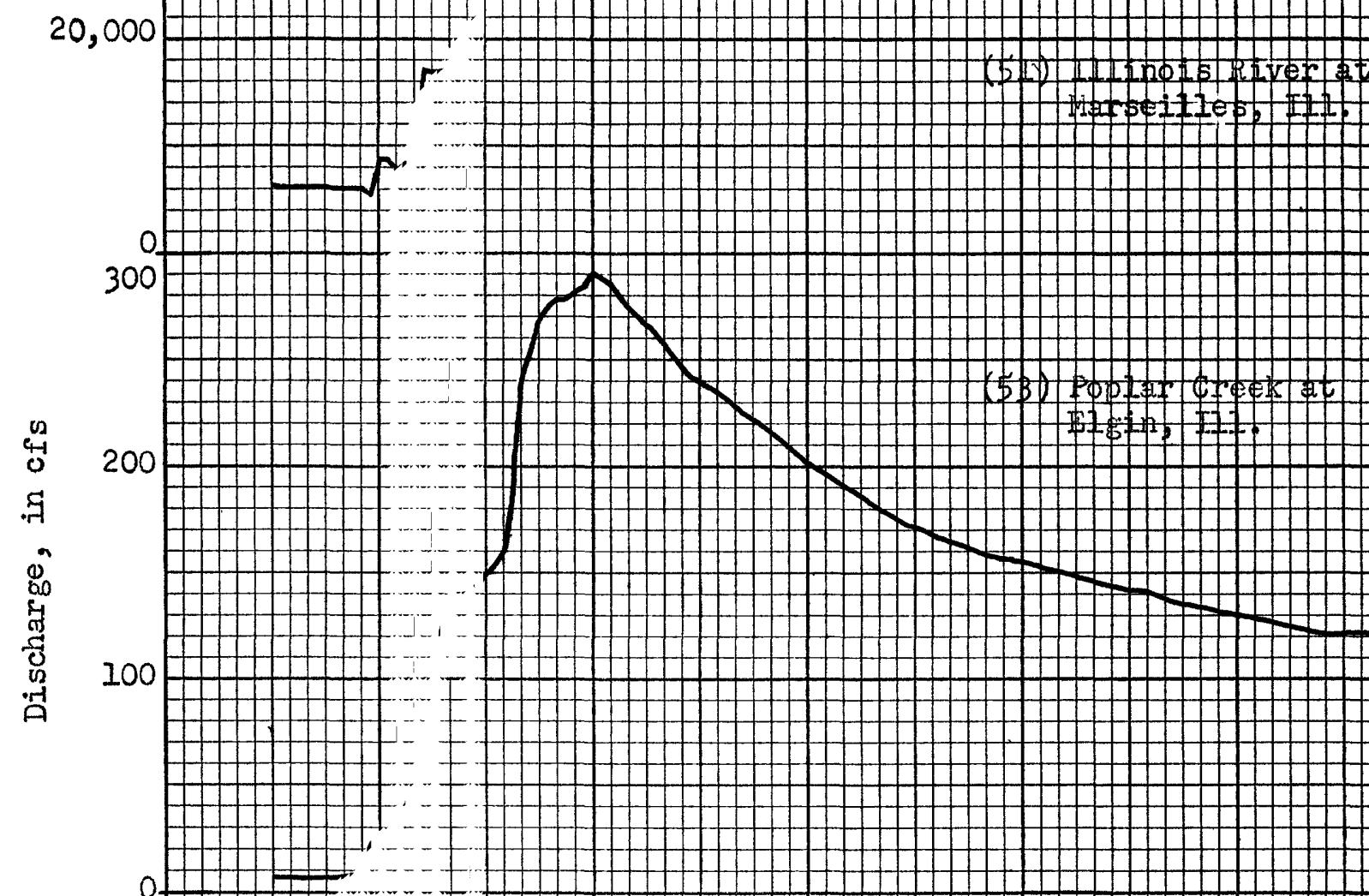

60,000

40,000
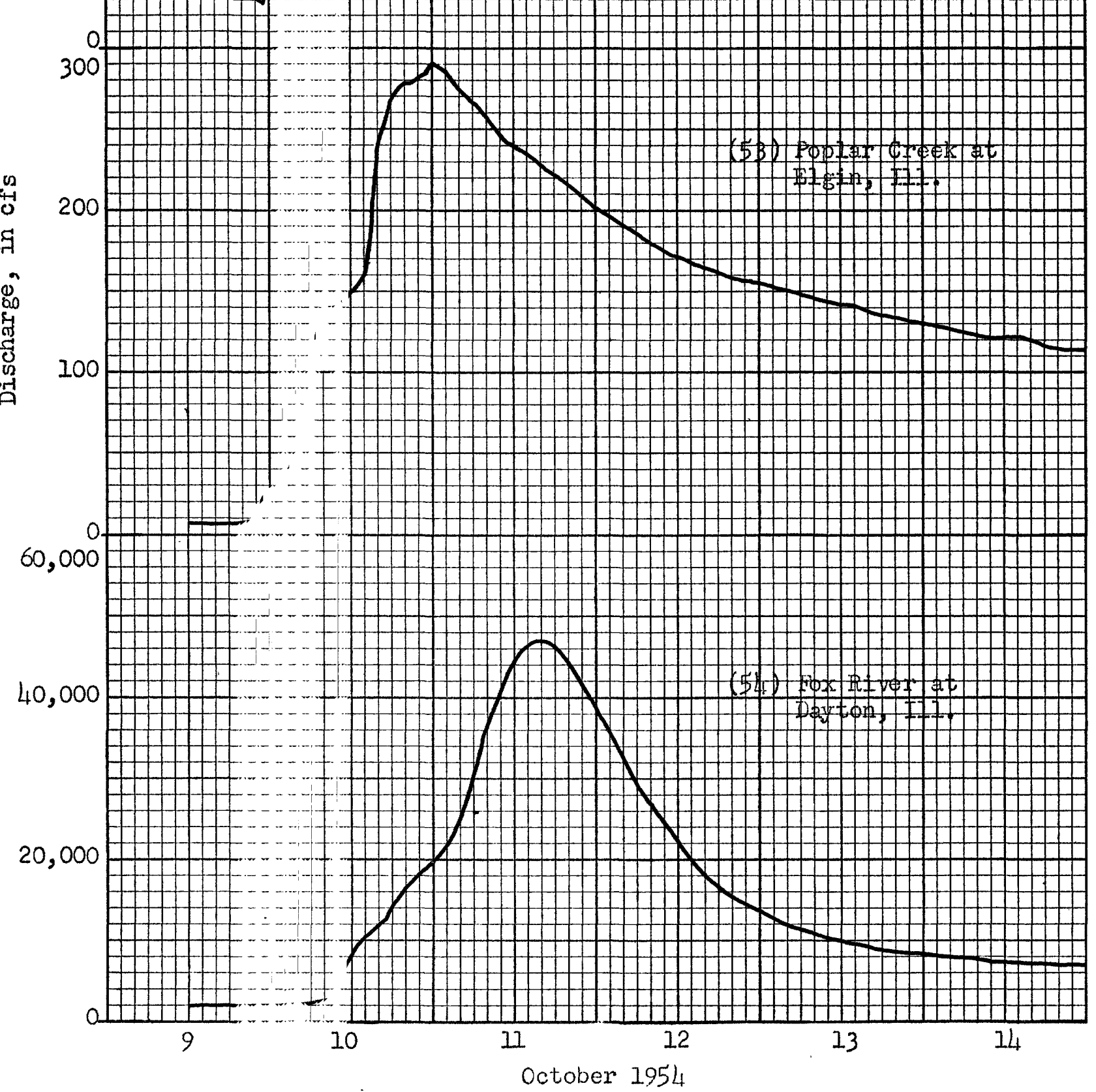

Figure 15.-Hydrographs for stations $51,53,54$ 


\section{SUMMARY OF FLOOD STAGES AND DISCHARGES}

The results of the determinations of maximum stages and discharges at the 50 established stream-gaging stations and 4 miscellaneous ungaged points in the area are summarized and presented in table 2. The reference numbers correspond to those assigned in the foregoing section, "Stages and discharges at stream-gaging stations", and in figures 1 and 2 .

The discharges listed in table 2 were determined at the established stream-gaging stations as explained in the descriptions of those stations. At the points where peak discharges were not determined by gaging-station operations, a general note at the end of the table indicates the method of determination: The peak-discharge values are given as actually determined; that is, no adjustments for artificlal storage, regulation or diversions have been attempted.

For some stations the peak discharge did not occur simultaneously with peak stage due to effects of slope, backwater, or for other reasons. In such instances, the maxima are given separately; first, the peak discharge and its date and time, and second, the peak stage and 1 ts date and time. A second line, also, is used to present data on floods prior to the period of gaging-station operation, where such historical information is available.

Peak discharges, in cubic feet per second per square mile, plotted against corresponding drainage areas are shown in figure 16. The reference numbers used throughout the report have been shown alongside the highest plotted points for gagingstation identity. 


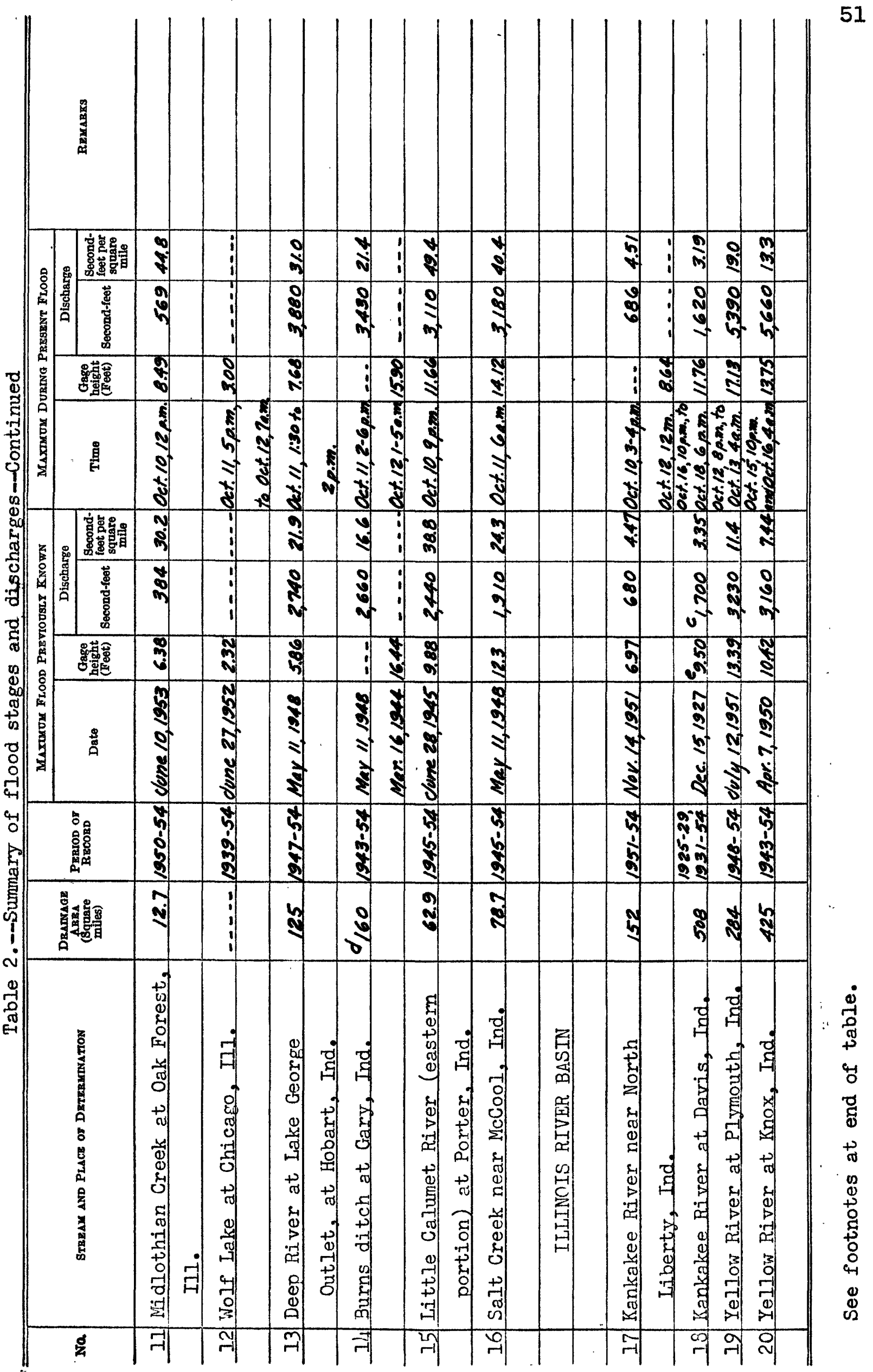




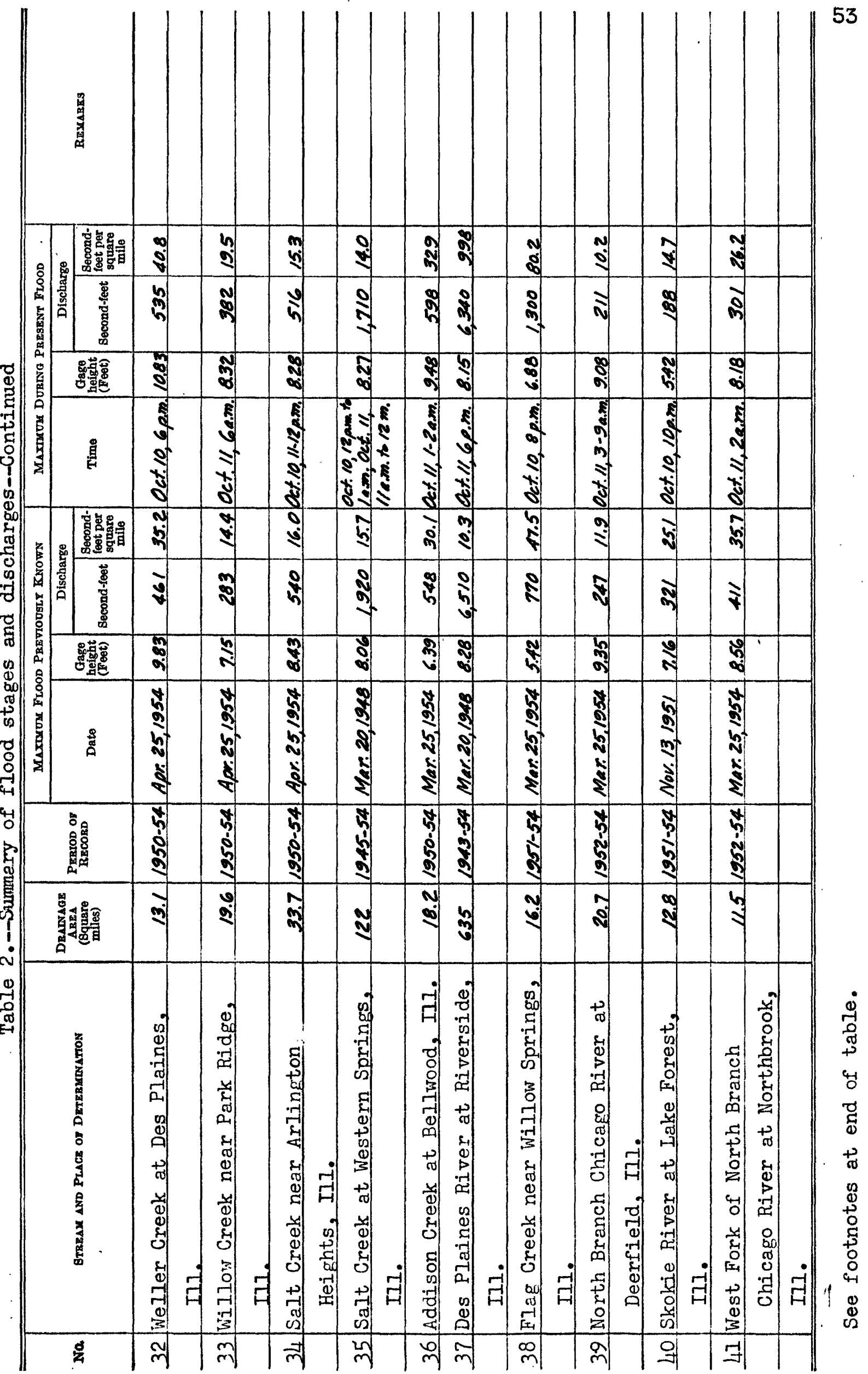




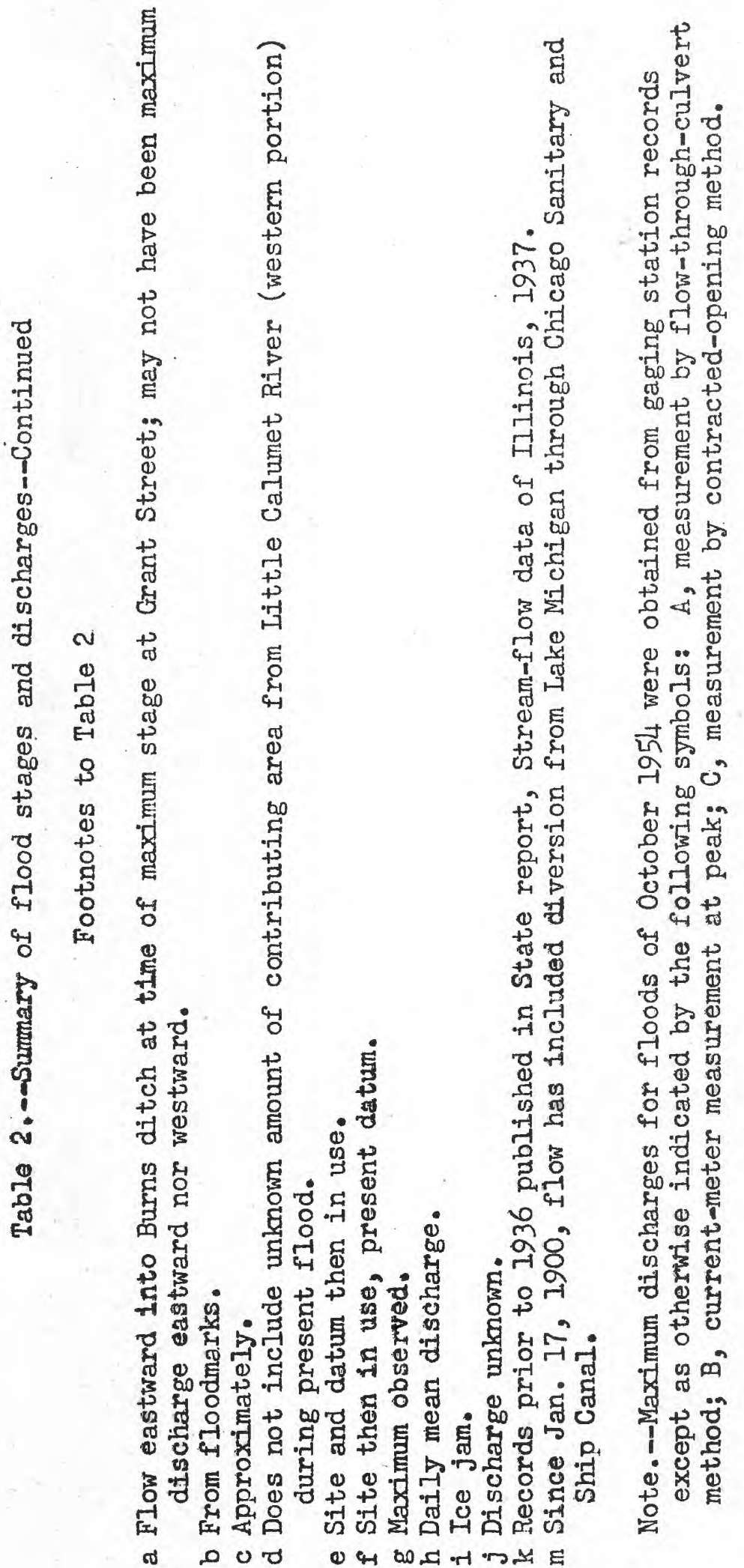




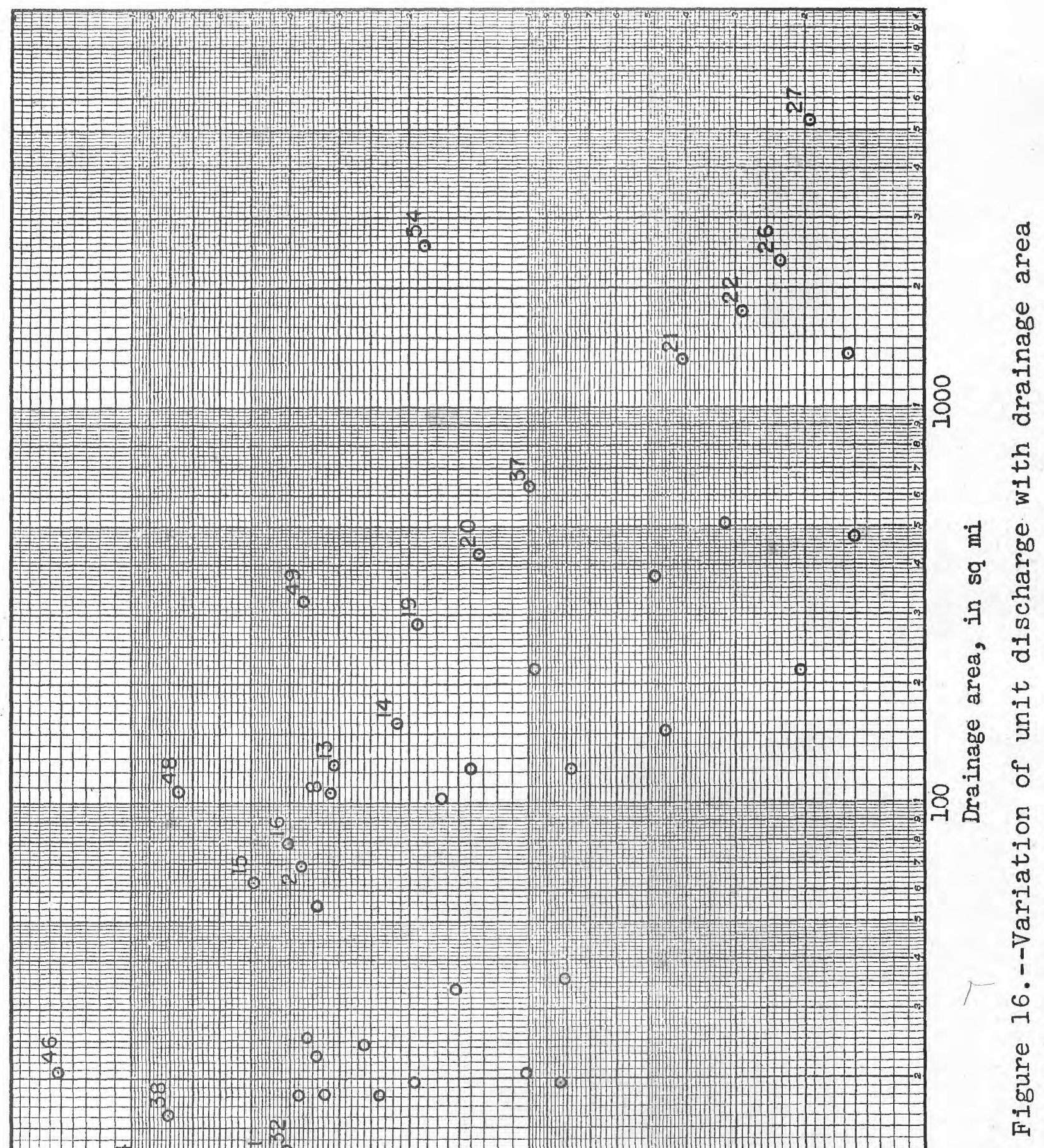




\section{FLOOD-FREQUENCY}

By reference to a plot of crest discharge, in cfs per sq $\mathrm{m} 1$, versus size of drainage area (see figure 16) it will be noted that the highest crest discharges for this flood may be closely approximated by the formula

$$
Q=925 \sqrt{\text { drainage area }}
$$

whereas highest crest discharges for the flood of 1943 in central Ilinois 1 , when analyzed in a similar manner, led to the formula

$$
Q=1850 \sqrt{\text { drainage area }}
$$

From these circumstances it might be inferred that the more recent flood was not of a magnitude that would justify unusual attention. To draw such a conclusion, however, is to disregard the difference in runoff characteristics between the two flood areas. Not only is northern Illinois generally subject to lighter rainfall than central Illinois, but also the land slopes are flatter, and the dralnage patterns are less well developed. Hence the normal rates of runoff for the northern portion of the state should be expected to be less than for the central portion. To emphasize the unusual nature of the 1954 flood, it should be compared with other floods on a basis which will allow for the difference in runoff characteristics. This is most conveniently done by making estimates of the probable recurrence interval.

Unfortunately, hydrologic data are too meager to provide close estimates for recurrence interval of the more outstanding floods. However, a recent analysis of floods in Illinols does provide a basis for some generalized comparisons?. By reference to that report it will be noted that, for the 1943 flood, there are no stations for whlch the recurrence interval appears to be much in excess of 100 years, and only a few stations for which the recurrence interval appears to be much in excess of 50 years. Using the curves from that same report, it will be noted that, for the $1954 \mathrm{flood}$, the recurrence interval for Du Page RIver at Troy appears to be about 80 years, and for Hickory Creek at Jollet and Fox River at Dayton it appears to be in excess of 100 years.

I] The Floods of May 1943 in Illinols, 1943, Ill. Dept. of Public Works and Bulldings, Div. of Waterways, Springfield, Ill.

2) Mitchell, W. D., 1954, Floods in Illino1s: Magnitude and Frequency, Ili. Dept. of Public Works and Bulldings, Div. of Waterways, Springfield, IIl. 
Flood-frequency curves have been developed for a few other stations within the area covered by the present report, but the drainage areas for these stations are generally outside the area of very high precipitation, so that the crest discharges were not unusually high. For the several stations of small drainage area which are located within the area of high precipitation, such as those which are tributary to Little Calumet River, the periods of record are so short that no magnitude-frequency relations have yet been developed. However, for several of these small areas, the basin lag has been computed from observed hydrographs. If 1 t is assumed that climatological factors for these areas are similar to those which have been derived and published for the adjacent wheaton morainal region, the probable recurrence interval may be est1mated from the observed values of lag. Such estimates indicate that, for at least a few of the small gaged areas which are tributary to Little Calumet Fiver, as well as for Long Run near Lemont, the recurrence interval of the 1954 flood may be in excess of 100 years.

on the other hand, it should be pointed out that for one of these small areas, Thorn Creek at Thornton, the orest discharge of the October 1954 flood has been exceeded twice during the elght years of record. On the basis of this information alone, the recurrence interval at Thornton would appear to be only a very few years; otherwise it is necessary to assume that three very unusual floods have occurred within the elght years of record. Obviously, a reliable estimate of recurrence interval in this section of the flood area must be postponed until longer records are available. 